\title{
13. RADIOLARIA FROM DSDP LEG 20
}

\author{
Helen P. Foreman, Oberlin College, Oberlin, Ohio
}

\section{INTRODUCTION}

Radiolaria in significant quantities were recovered from holes drilled at five of the eight sites investigated. Their localities are as follows:

Site $194-33^{\circ} 58.66^{\prime} \mathrm{N}, 148^{\circ} 48.64^{\prime} \mathrm{E}$; depth of water 5754 meters.

Site $195-32^{\circ} 46.05^{\prime} \mathrm{N}, 146^{\circ} 59.0^{\prime} \mathrm{E}$; depth of water 5968 meters.

Site $196-30^{\circ} 06.97^{\prime} \mathrm{N}, 148^{\circ} 34.49^{\prime} \mathrm{E}$; depth of water 6194 meters.

Site $198-25^{\circ} 49.54^{\prime} \mathrm{N}, 154^{\circ} 35.05^{\prime} \mathrm{E}$; depth of water 5858 meters.

Site $199-13^{\circ} 30.78^{\prime} \mathrm{N}, 156^{\circ} 46.96^{\circ} \mathrm{E}$; depth of water 6100 meters.

The holes at these sites were all drilled at abyssal depths in the northwest Pacific basin.

Early Cretaceous Radiolaria were recovered from Holes 194, 195, and 196; Late Cretaceous from Holes 196 and 198; Neogene from Holes 194, 195, and 196; and mixed Oligocene and older forms in Core 5 of Hole 199.

The presence of moderately well preserved Early Creta. ceous Radiolaria and their cooccurrence in many of the samples with nannofossils is of considerable significance, and the main portion of this paper is thus devoted to the Radiolaria found in this part of the geologic column.

\section{MATERIAL TREATED AND PRESENTATION OF RESULTS}

Because the Neogene and late Cretaceous material is better known and because this material is represented by isolated cores with no sequence of any significance available for study, the major part of this work is concerned with the Early Cretaceous Radiolaria which frequently cooccurred with nannofossils at Sites 194, 195, and 196.

For the Neogene samples, only the diagnostic fossils are listed, together with the zonal assignments that were made.

For the samples from the late Cretaceous of Campanian age (196-2, 198-4, and 198-5) diagnostic fossils are listed, and they are illustrated on Plate 15. Sample 195-3, CC, Late Cretaceous, possibly Cenomanian, is treated in somewhat greater detail because of the difficulty in ascertaining its exact level in the late Cretaceous. Forms from this sample are illustrated on Plate 14; one species is described and others are briefly treated in the taxonomic section.

From the Early Cretaceous material new taxa have been described and three informal assemblages defined. Occurrences for all of the new and some of the previously described species, together with their abundance, have been recorded (Tables 1-3). From these data a list of events (Table 4) has been made which gives in chronological order the first and last appearance for each species in each hole. A range chart (Figure 1), based on a composite of samples from Holes 194, 195, 195B, and 196, summarizes the results.

From Cores 196-3 and 196-4 only pieces of chert, siliceous limestones, and mudstones were recovered. All the soft sediment was washed out in the drilling operation. Because it is not possible to determine the position in the ten meter core of these pieces of hard rock, they have been arbitrarily assigned to section 1 and labeled from youngest to oldest, piece 1,2 , etc., rather than having their position given in centimeters within the section.

Among the Cretaceous Radiolaria are numerous spherical spumellarians and cryptocephalic and cryptothoracic nassellarians similar to those described by Tan Sin Hok (1927) and Dumitrica (1970). In some orientations it is not possible to distinguish between these two groups. Many species are superficially similar, and they have not been treated at this time because of the difficulty of working with these species when material is poorly preserved and internal distinguishing structures cannot be observed.

\section{RADIOLARIA FROM EACH SITE}

Lower Cretaceous Radiolaria from Sites 194, 195, and 196 have been recorded on Tables 1-3 with the relative abundance of each species given as follows: $C$, common (more than 20 specimens on a slide); $F$, few (6-20 specimens on a slide); $R$, rare ( 2.5 specimens on a slide) ++ , one specimen on a number of slides; and a dot, an isolated specimen. A dash indicates the species has been searched for and not found. The abbreviations $C$, common and $F$, few, have also been used in a more general sense under a column headed "abundance" to indicate the quantity of Radiolaria in the sample studied. The quality of preservation is indicated by $M$, moderate and $P$, poor. Only the degree of corrosion is indicated, not whether specimens are broken.

\section{Radiolaria from Hole 194}

Only siliceous microfossils were recovered from Hole 194 (Table 1).

\section{Cenozoic Sediments}

In Core 1 (37.5-47 meters below the sediment surface), radiolarians are few and silicoflagellates and diatoms rare. The radiolarians and silicoflagellates are well preserved and the diatoms moderately well preserved. In Core 2 (142-151.5 meters below the sediment surface), radiolarians are common to abundant, silicoflagellates few to rare, and diatoms common. All are well preserved.

If Hay's (1970) zonation for the north Pacific is applicable this far south, as indicated by Kling (1971), the absence of Eucyrtidium matuyamai and Lamprocyrtis heteroporos together with the presence of Stylacontarium acquilonium, Lamprocyrtis haysi, and Axoprunum 
TABLE 1

Occurrence and Abundance of Radiolaria in Hole 194

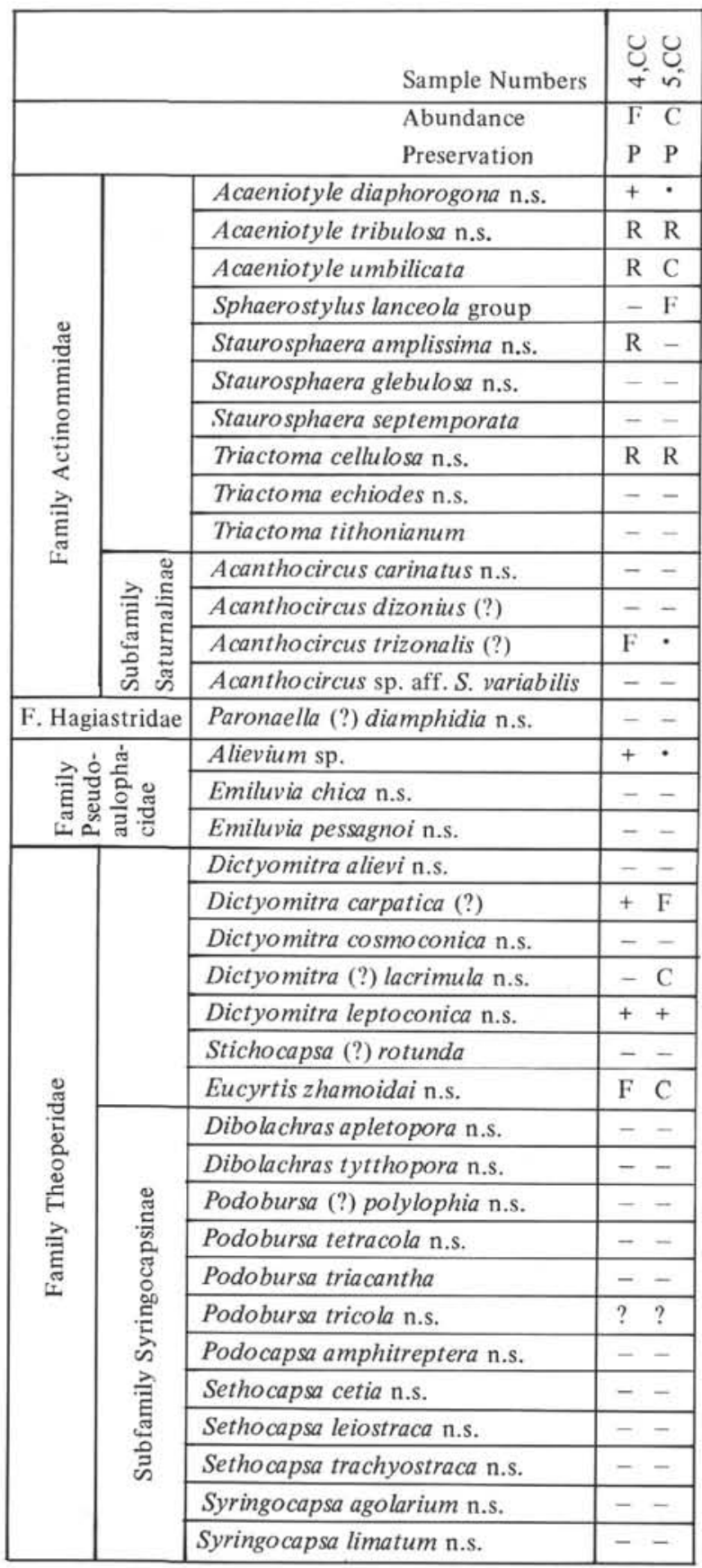

Note: See text for an explanation of symbols.

angelinum suggest that Core 1 is early late Pleistocene in age (Axoprunum angelinum Zone). ${ }^{1}$ Also present are some rare tropical Quaternary forms, among them Spongaster tetras tetras. Among the silicoflagellates the presence of Dictyocha fibula var. aculeata throughout the core indicates a Pleistocene to Recent age, according to Ling (1972).

\footnotetext{
${ }^{1}$ Zone names for the northern Pacific Pliocene-Quaternary used here follow Kling (1973) except that the Eucyrtidium tumidulum Zone name of Hays (1970) remains unchanged.
}

TABLE 2

Occurrence and Abundance of Radiolaria in Holes 195 and 195B

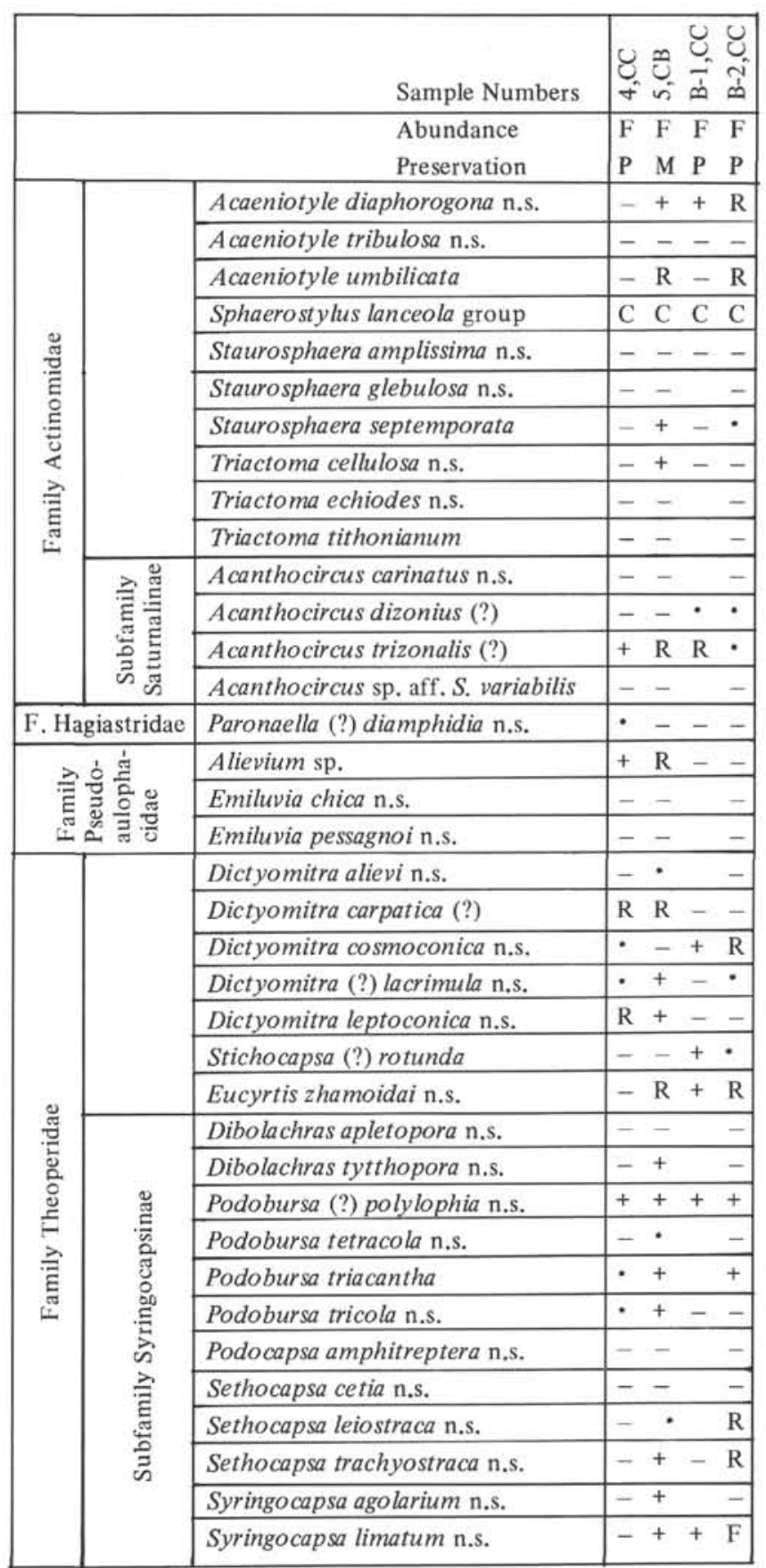

Note: See text for an explanation of symbols.

Core $2(142-151.5$ meters below the sediment surface) is below the range of the zonation established for the north Pacific, and age is here determined on the basis of a few forms whose ranges have been established in tropical sequences. The presence throughout of common Stichocorys peregrina and very rare Spongaster klingi?, together with, in the lower half of the core, very rare Ommatartus penultimus and $O$. avitus, indicates that this core is late Miocene (Stichocorys peregrina Zone). Among the silicoflagellates the navicular form of Dictyocha mutabilis is common, and Distephanus speculum var. pentagonus forma 
TABLE 3

Occurrence and Abundance of Radiolaria in Hole 196

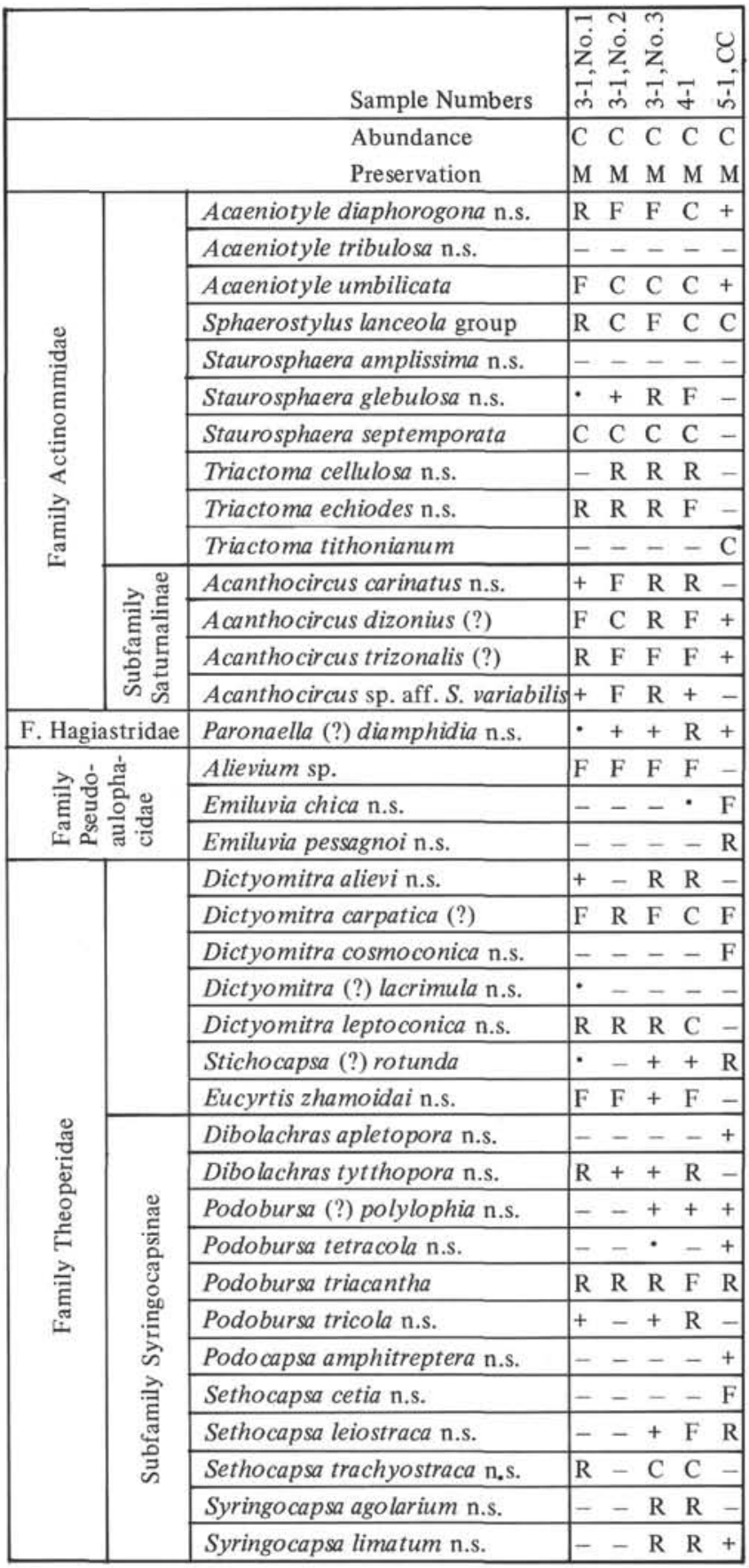

Note: See text for an explanation of symbols.

armatus and Dictyocha crux forma parva are very rare. The ranges for these silicoflagellates are not known, but the former two have been reported from the middle Miocene (Helvetian) and the latter from the early late Miocene.

\section{Mesozoic Sediments}

From Cores 3, 4, and 5 (at 227.5-237, 237-246.5, and 246.5-247 meters below the sediment surface, respectively) only core catcher samples of chert were recovered. A dark brown chert sample from Core 3 yielded rare radiolarians, too poor to identify confidently. Presumably, they are of Early Cretaceous age. Radiolarians in the white and red chert of Core 4 and the white and brown chert of Core 5 are common, moderately to poorly preserved, of Early Cretaceous age (Acaeniotyle tribulosa assemblage), and younger than those in 196-3, which according to nannofossils is considered to be Valanginian-Early Hauterivian. The bit sample at a total depth of 6010 meters ( 256 meters below the sediment surface) yielded a few poorly preserved radiolarians, presumably Early Cretaceous in age.

\section{Radiolaria from Holes 195 and 195B}

Radiolarians, silicoflagellates, diatoms, nannofossils, and foraminifera were recovered from this site (Table 2).

\section{Cenozoic Sediments}

In Hole 195 only siliceous fossils were recovered from sediments of Cenozoic age. Radiolaria are well preserved in Cores 1 (63-72.5 meters below the sediment surface) and 2 (120-129.5 meters below the sediment surface). They are common in Core 1 and the first section of Core 2 and few in the remaining sections of Core 2. Silicoflagellates are common and well preserved only in Core 1. Diatoms are few and well preserved in both Cores 1 and 2 .

Based on Hays' (1970) zonation for Radiolaria in the north Pacific, the presence of Lamprocyrtis heteroporos throughout Core 1 and rare Eucyrtidium matuyamai in the first two sections suggests that the lower part of the core is Pliocene and the upper part transitional between the Pliocene and Pleistocene. The zonation of Riedel and Sanfilippo (1970) and the species ranges of Riedel and Sanfilippo (1971) for the equatorial Pacific tend to confirm this conclusion. Pterocanium prismatium is rare throughout the core, and Spongaster tetras tetras, while never common, increases in frequency toward the top of the core, suggesting again a transition from the Pliocene to the Quaternary. The presence of fairly frequent Ommatartus avitus in Section 6 only is anomalous.

Core 2 is below the range of the zonation established for the north Pacific, and the age assignment is based on the zonation established for the equatorial Pacific. The presence of a few Stichocorys peregrina together with rare Stichocorys delmontensis suggests a late Miocene age (Stichocorys peregrina Zone), slightly older than 194-2.

\section{Mesozoic Sediments}

Radiolaria were recovered from all the core catcher and bit samples of Mesozoic age at Site 195 and nannofossils from Hole 195 center bits 4 and 5, Hole 195A center bit 1 , and all Hole 195B core catchers. Foraminifera were recovered from 195B-3 only.

From 195-3, CC (190-196 meters below the sediment surface) five chert samples were examined. Radiolaria in them ranged from common and moderately well preserved to few and poorly preserved. All samples contained some elements of a similar fauna, although not all of the distinctive species noted were present in all the samples. One distinctive form, Dictyomitra somphedia, present in three of the samples examined, is described in detail. A number of the species observed are closely related to some 
TABLE 4

Radiolarian Events for Holes 194, 195, 195B, and 196

\begin{tabular}{|c|c|c|c|c|c|c|c|}
\hline \multirow[b]{2}{*}{ T Staurosphaera amplissima } & \multicolumn{3}{|c|}{ Hole 194} & \multicolumn{2}{|c|}{ Hole 195 and $195 \mathrm{~B}$} & \multicolumn{2}{|c|}{ Hole 196} \\
\hline & $\begin{array}{l}4, \mathrm{CC} \\
(237) \\
\end{array}$ & to & $\begin{array}{l}2, \mathrm{CC} G \\
(149)\end{array}$ & - & & - & \\
\hline $\mathrm{T}$ Acaeniotyle tribulosa & $\begin{array}{l}4, \mathrm{CC} \\
(237) \\
\end{array}$ & to & $\begin{array}{l}2, \mathrm{CC} G \\
(149)\end{array}$ & - & & - & \\
\hline $\mathrm{T}$ Alievium sp. & $\begin{array}{l}4, \mathrm{CC} \\
(237)\end{array}$ & to & $\begin{array}{l}2, \mathrm{CC} G \\
(149)\end{array}$ & $\begin{array}{ll}4, \mathrm{CC} & \text { to } \\
(272)\end{array}$ & $\begin{array}{l}3, C C \mathrm{G} \\
(187)\end{array}$ & $\begin{array}{l}\begin{array}{l}3-1, \text { no. } 1 \text { to } \\
(197)\end{array} \\
\end{array}$ & $\begin{array}{l}2, C C \quad G \\
(113)\end{array}$ \\
\hline T Triactoma cellulosa & $\begin{array}{l}4, \mathrm{CC} \\
(237)\end{array}$ & to & $\begin{array}{l}2, C C G \\
(149)\end{array}$ & $\begin{array}{l}5, \mathrm{CB} \text { to } \\
(278-310)\end{array}$ & $\begin{array}{l}4, \text { CC M } \\
(272)\end{array}$ & \begin{tabular}{|l|} 
Within 3-1 \\
$(197-203)$ \\
\end{tabular} & $\mathrm{M}$ \\
\hline T Dictyomitra leptoconica & $\begin{array}{l}4, \mathrm{CC} \\
(237)\end{array}$ & to & $\begin{array}{l}2, \mathrm{CC} \mathrm{G} \\
(145)\end{array}$ & $\begin{array}{ll}4, \mathrm{CC} & \text { to } \\
(272)\end{array}$ & $\begin{array}{l}3, \text { CC G } \\
(187)\end{array}$ & $\begin{array}{l}\begin{array}{l}3-1, \text { no. } 1 \text { to } \\
(197)\end{array} \\
\end{array}$ & $\begin{array}{l}2, C C \quad G \\
(113)\end{array}$ \\
\hline T Podobursa tricola & $\begin{array}{l}4, \mathrm{CC} \\
(237)\end{array}$ & to & $\begin{array}{l}2, \mathrm{CC} \mathrm{M} \\
(145)\end{array}$ & $\begin{array}{l}4, \mathrm{CC} \\
(272)\end{array}$ & $\begin{array}{l}3, \text { CC G } \\
(187)\end{array}$ & $\begin{array}{l}\text { 3-1, no. } 1 \text { to } \\
(197)\end{array}$ & $\begin{array}{l}\text { 2, CC G } \\
(113)\end{array}$ \\
\hline $\mathrm{T}$ Eucyrtis zhamoidai & $\begin{array}{l}4, \mathrm{CC} \\
(237)\end{array}$ & to & $\begin{array}{l}\text { 2, CC G } \\
(149)\end{array}$ & $\begin{array}{l}4, \mathrm{CC} \\
(272)\end{array}$ & $\begin{array}{l}\text { 3, CC G } \\
(187)\end{array}$ & $\begin{array}{l}\text { 3-1, no. } 1 \text { to } \\
(197)\end{array}$ & $\begin{array}{l}2, \mathrm{CC} \quad \mathrm{G} \\
(113)\end{array}$ \\
\hline $\mathrm{T}$ Acaeniotyle diaphorogona & $\begin{array}{l}4, \mathrm{CC} \\
(237)\end{array}$ & to & $\begin{array}{l}2, \text { CC G } \\
(149)\end{array}$ & $\begin{array}{l}5, \mathrm{CB} \text { to } \\
(278-310)\end{array}$ & $\begin{array}{l}4, \text { CC M } \\
(272)\end{array}$ & $\begin{array}{l}\text { 3-1, no. } 1 \text { to } \\
(197)\end{array}$ & $\begin{array}{l}2, \mathrm{CC} \quad \mathrm{G} \\
\text { (113) }\end{array}$ \\
\hline $\mathrm{T}$ Acanthocircus trizonalis (?) & $\begin{array}{l}4, \mathrm{CC} \\
(237)\end{array}$ & to & $\begin{array}{l}2, \text { CC G } \\
(149)\end{array}$ & $\begin{array}{ll}4, \mathrm{CC} & \text { to } \\
(272)\end{array}$ & $\begin{array}{l}, \text { CC G } \\
(187)\end{array}$ & \begin{tabular}{|l|}
$\begin{array}{l}3-1, \text { no. } 1 \text { to } \\
(197)\end{array}$ \\
\end{tabular} & $\begin{array}{l}2, \mathrm{CC} \text { G } \\
(113)\end{array}$ \\
\hline T Dictyomitra carpatica (?) & $\begin{array}{l}4, \mathrm{CC} \\
(237)\end{array}$ & to & $\begin{array}{l}2, \text { CC G } \\
(149)\end{array}$ & $\begin{array}{ll}4, \mathrm{CC} & \text { to } \\
(272)\end{array}$ & $\begin{array}{l}3, \text { CC G } \\
(187)\end{array}$ & $\begin{array}{l}\text { 3-1, no. } 1 \text { to } \\
(197)\end{array}$ & $\begin{array}{l}2, \mathrm{CC} \quad \mathrm{G} \\
(113)\end{array}$ \\
\hline $\mathrm{T}$ Acaeniotyle umbilicata & $\begin{array}{l}4, \mathrm{CC} \\
(237)\end{array}$ & to & $\begin{array}{l}2, \text { CC G } \\
(149)\end{array}$ & \begin{tabular}{|l}
$5, \mathrm{CB}$ to \\
$(278-310)$
\end{tabular} & $\begin{array}{l}4, \text { CC P } \\
(272)\end{array}$ & $\begin{array}{l}\text { 3-1, no. } 1 \text { to } \\
(197)\end{array}$ & $\begin{array}{l}2, \mathrm{CC} \\
(113) \\
\end{array}$ \\
\hline B Staurosphaera amplissima & $\begin{array}{l}5, \mathrm{CC} \\
(247) \\
\end{array}$ & to & $\begin{array}{l}4, C C \mathrm{G} \\
(237)\end{array}$ & - & & - & \\
\hline T Dictyomitra (?) lacrimula & $\begin{array}{l}5, \mathrm{CC} \\
(247)\end{array}$ & to & $\begin{array}{l}4, \mathrm{CC} M \\
(237)\end{array}$ & $\begin{array}{ll}4, \mathrm{CC} & \text { to } \\
(272) & \\
\end{array}$ & $\begin{array}{l}3, \mathrm{CC} G \\
(187)\end{array}$ & \begin{tabular}{|l|}
$\begin{array}{l}3-1, \text { no. } 1 \text { to } \\
(197)\end{array}$ \\
\end{tabular} & $\begin{array}{ll}2, \mathrm{CC} & \mathrm{M} \\
(113) & \\
\end{array}$ \\
\hline T Sphaerostylus lanceola & $\begin{array}{l}5, \mathrm{CC} \\
(247)\end{array}$ & to & $\begin{array}{l}4, \text { CC M } \\
(237)\end{array}$ & \begin{tabular}{|ll}
$4, \mathrm{CC}$ & to \\
$(272)$ & \\
\end{tabular} & $\begin{array}{l}\text { 3, CC M } \\
(187)\end{array}$ & \begin{tabular}{|l}
$\begin{array}{l}3-1, \text { no. } 1 \text { to } \\
(197)\end{array}$ \\
\end{tabular} & $\begin{array}{l}2, \mathrm{CC} \quad \mathrm{G} \\
(113)\end{array}$ \\
\hline B Acaeniotyle tribulosa & Below & & $\begin{array}{l}5, \text { CC G } \\
(247)\end{array}$ & - & & - & \\
\hline T Podobursa triacantha & & - & & $\begin{array}{ll}4, \mathrm{CC} & \text { to } \\
(272) & \end{array}$ & $\begin{array}{l}\text { 3, CC G } \\
\text { (187) }\end{array}$ & \begin{tabular}{|l|}
$\begin{array}{l}3-1, \text { no. } 1 \text { to } \\
(197)\end{array}$ \\
\end{tabular} & $\begin{array}{l}2, \mathrm{CC} \quad \mathrm{G} \\
(113)\end{array}$ \\
\hline T Paronaella (?) diamphidia & & - & & $\begin{array}{ll}4, \mathrm{CC} & \text { to } \\
(272) & \end{array}$ & $\begin{array}{l}3, \mathrm{CC} \mathrm{G} \\
(187)\end{array}$ & \begin{tabular}{|l|}
$3-1$, no. 1 to \\
$(197)$
\end{tabular} & $\begin{array}{l}2, \mathrm{CC} \quad \mathrm{G} \\
(113)\end{array}$ \\
\hline T Podobursa (?) polylophia & & - & & $\begin{array}{ll}4, \mathrm{CC} & \text { to } \\
(272) & \\
\end{array}$ & $\begin{array}{l}3, \mathrm{CC} \mathrm{G} \\
(187)\end{array}$ & \begin{tabular}{|l|} 
Within 3-1 \\
$(197-203)$ \\
\end{tabular} & \\
\hline $\mathrm{T}$ Dibolachras tytthopora & & - & & $\begin{array}{l}\text { 5, CB to } \\
(278-310)\end{array}$ & $\begin{array}{l}\text { 4, CC M } \\
(272)\end{array}$ & $\begin{array}{l}\text { 3-1, no. } 1 \text { to } \\
(197)\end{array}$ & $\begin{array}{l}\text { 2, CC G } \\
\text { (113) }\end{array}$ \\
\hline T Staurosphaera septemporata & & - & & $\begin{array}{l}5, \mathrm{CB} \text { to } \\
(278-310)\end{array}$ & $\begin{array}{l}\begin{array}{l}4, \mathrm{CC} M \\
(272)\end{array} \\
\end{array}$ & $\begin{array}{l}\text { 3-1, no. } 1 \text { to } \\
(197)\end{array}$ & $\begin{array}{l}2, \mathrm{CC} \text { G } \\
(113)\end{array}$ \\
\hline T Sethocapsa trachyostraca & & - & & $\begin{array}{l}5, \mathrm{CB} \text { to } \\
(278-310)\end{array}$ & $\begin{array}{l}4, \mathrm{CC} M \\
(272)\end{array}$ & \begin{tabular}{|l|}
$\begin{array}{l}3-1, \text { no. } 1 \text { to } \\
(197)\end{array}$ \\
\end{tabular} & $\begin{array}{l}2, C C \quad G \\
(113)\end{array}$ \\
\hline T Syringocapsa agolarium & & - & & $\begin{array}{l}5, \mathrm{CB} \text { to } \\
(278-310)\end{array}$ & $\begin{array}{l}4, \text { CC M } \\
(272)\end{array}$ & $\begin{array}{l}\text { Within 3-1 } \\
(197-203)\end{array}$ & \\
\hline T Syringocapsa limatum & & - & & $\begin{array}{l}5, \mathrm{CB} \text { to } \\
(278-310)\end{array}$ & $\begin{array}{l}4, \text { CC M } \\
(272)\end{array}$ & $\begin{array}{l}\text { Within 3-1 } \\
(197-203)\end{array}$ & \\
\hline $\mathrm{T}$ Sethocapsa leiostraca & & - & & $\begin{array}{l}5, \mathrm{CB} \text { to } \\
(278-310)\end{array}$ & $\begin{array}{l}\text { 4, CC M } \\
(272)\end{array}$ & $\begin{array}{l}\text { Within 3-1 } \\
\text { (197-203) }\end{array}$ & \\
\hline T Podobursa tetracola & & - & & $\begin{array}{l}5, \mathrm{CB} \text { to } \\
(278-310)\end{array}$ & $\begin{array}{l}4, \mathrm{CC} M \\
(272)\end{array}$ & $\begin{array}{l}\text { Within 3-1 } \\
(197-203) \\
\end{array}$ & \\
\hline $\mathrm{T}$ Dictyómitra alievi & & - & & $\begin{array}{l}5, \mathrm{CB} \text { to } \\
(278-310)\end{array}$ & $\begin{array}{l}\text { 4, CC M } \\
(272)\end{array}$ & $\begin{array}{l}\text { 3-1, no. } 1 \text { to } \\
(197)\end{array}$ & $\begin{array}{l}\text { 2, CC G } \\
\text { (113) }\end{array}$ \\
\hline
\end{tabular}


TABLE 4 -Continued

\begin{tabular}{|c|c|c|c|c|c|c|c|c|}
\hline \multirow[b]{2}{*}{ T Acanthocircus carinatus } & \multicolumn{2}{|c|}{ Hole 194} & \multicolumn{2}{|c|}{ Hole 195 and 195B } & \multicolumn{4}{|c|}{ Hole 196} \\
\hline & & & & - & $\begin{array}{l}3-1, \text { no. } 1 \\
(197)\end{array}$ & & $\begin{array}{l}2, \mathrm{CC} \\
(113)\end{array}$ & G \\
\hline $\begin{array}{l}\text { T Acanthocircus sp. aff. } \\
\text { S. variabilis }\end{array}$ & & & & - & $\begin{array}{l}\text { 3-1, no. } 1 \\
(197)\end{array}$ & to & $\begin{array}{l}2, \mathrm{CC} \\
(113)\end{array}$ & G \\
\hline $\mathrm{T}$ Triactoma echoides & & & & - & $\begin{array}{l}3-1, \text { no. } 1 \\
(197)\end{array}$ & & $\begin{array}{l}2, \mathrm{CC} \\
(113)\end{array}$ & G \\
\hline T Staurosphaera glebulosa & & & & - & $\begin{array}{l}\text { 3-1, no. } 1 \\
(197)\end{array}$ & to & $\begin{array}{l}2, \mathrm{CC} \\
(113)\end{array}$ & G \\
\hline $\mathrm{T}$ Acanthocircus dizonius & & & $\begin{array}{l}\text { B-1, CC } \\
(357)\end{array}$ & $\begin{array}{l}\text { to 5, CB M } \\
(278-310)\end{array}$ & $\begin{array}{l}\text { 3-1, no. } 1 \\
(197)\end{array}$ & to & $\begin{array}{l}2, \mathrm{CC} \\
(113) \\
\end{array}$ & G \\
\hline T Stichocapsa (?) rotunda & & & $\begin{array}{l}\text { B-1, CC } \\
(357)\end{array}$ & $\begin{array}{l}\text { to 5, CB G } \\
(278-310)\end{array}$ & \begin{tabular}{|l|}
$3-1$, no. 1 \\
$(197)$
\end{tabular} & to & $\begin{array}{l}2, \mathrm{CC} \\
(113)\end{array}$ & G \\
\hline $\mathrm{T}$ Emiluvia chica & & & & - & $\begin{array}{l}4-1 \\
(301)\end{array}$ & to & $\begin{array}{l}\text { 3-1, no. } \\
(197)\end{array}$ & \\
\hline T Dictyomitra cosmoconica & & & $\begin{array}{l}4, \mathrm{CC} \\
(272)\end{array}$ & \begin{tabular}{ll|} 
to & $\begin{array}{l}3, \mathrm{CC} P \\
(187)\end{array}$ \\
\end{tabular} & \begin{tabular}{|l|}
$5, \mathrm{CC}$ \\
$(361)$ \\
\end{tabular} & to & $\begin{array}{l}4-1 \\
(301)\end{array}$ & M \\
\hline B Alievium sp. & Below & $\begin{array}{l}5, \text { CC G } \\
(247)\end{array}$ & \begin{tabular}{|l|} 
B-1, CC \\
$(357)$
\end{tabular} & $\begin{array}{l}\text { to 5, CB M } \\
(278-310)\end{array}$ & $\begin{array}{l}5, \mathrm{CC} \\
(361) \\
\end{array}$ & to & $\begin{array}{l}4-1 \\
(301)\end{array}$ & G \\
\hline B Triactoma cellulosa & Below & $\begin{array}{l}5, \mathrm{CC} \text { G } \\
(247)\end{array}$ & \begin{tabular}{|l|}
$\begin{array}{l}\text { B-1, CC } \\
(357)\end{array}$ \\
\end{tabular} & $\begin{array}{l}\text { to 5, CB M } \\
(202-278)\end{array}$ & \begin{tabular}{|l|}
$5, \mathrm{CC}$ \\
$(361)$ \\
\end{tabular} & to & $\begin{array}{l}4-1 \\
(301) \\
\end{array}$ & G \\
\hline B Dictyomitra leptoconica & Below & $\begin{array}{l}5, \mathrm{CC} \mathrm{G} \\
(247)\end{array}$ & \begin{tabular}{|l|}
$\begin{array}{l}\text { B-1, CC } \\
(357)\end{array}$ \\
\end{tabular} & $\begin{array}{l}\text { to 5, CB M } \\
(278-310)\end{array}$ & \begin{tabular}{|l}
$5, \mathrm{CC}$ \\
$(361)$ \\
\end{tabular} & to & $\begin{array}{l}4-1 \\
(301) \\
\end{array}$ & G \\
\hline B Podobursa tricola & Below & $\begin{array}{l}5, \mathrm{CC} M \\
(247)\end{array}$ & \begin{tabular}{|l|}
$\begin{array}{l}\text { B-1, CC } \\
(357)\end{array}$ \\
\end{tabular} & $\begin{array}{l}\text { to 5, CB G } \\
(278-310)\end{array}$ & $\begin{array}{l}5, \mathrm{CC} \\
(361) \\
\end{array}$ & to & $\begin{array}{l}4-1 \\
(301)\end{array}$ & G \\
\hline B Dibolachras tytthopora & & & \begin{tabular}{|l|}
$\begin{array}{l}\text { B-1, CC } \\
(357)\end{array}$ \\
\end{tabular} & $\begin{array}{l}\text { to 5, CB G } \\
(278-310)\end{array}$ & $\begin{array}{l}5, \mathrm{CC} \\
(361) \\
\end{array}$ & to & $\begin{array}{l}4-1 \\
(301)\end{array}$ & G \\
\hline B Syringocapsa agolarium & & & \begin{tabular}{|l|}
$\begin{array}{l}\text { B-1, CC } \\
(357)\end{array}$ \\
\end{tabular} & $\begin{array}{l}\text { to 5, CB M } \\
(278-310)\end{array}$ & \begin{tabular}{|l|}
$5, \mathrm{CC}$ \\
$(361)$ \\
\end{tabular} & to & $\begin{array}{l}4-1 \\
(301)\end{array}$ & G \\
\hline B Dictyomitra alievi & & & \begin{tabular}{|l|}
$\begin{array}{l}\text { B-1, CC } \\
(357)\end{array}$ \\
\end{tabular} & $\begin{array}{l}\text { to 5, CB P } \\
(278-310)\end{array}$ & \begin{tabular}{|l|}
$5, \mathrm{CC}$ \\
$(361)$ \\
\end{tabular} & to & $\begin{array}{l}4-1 \\
(301)\end{array}$ & G \\
\hline B Acanthocircus carinatus & & & & - & $\begin{array}{l}5, \mathrm{CC} \\
(361) \\
\end{array}$ & to & $\begin{array}{l}4-1 \\
(301)\end{array}$ & G \\
\hline $\begin{array}{l}\text { B Acanthocircus sp. aff. } \\
\text { S. variabilis }\end{array}$ & & & & - & $\begin{array}{l}5, \mathrm{CC} \\
(361)\end{array}$ & to & $\begin{array}{l}4-1 \\
(301) \\
\end{array}$ & G \\
\hline B Triactoma echiodes & & & & - & $\begin{array}{l}5, \mathrm{CC} \\
(361) \\
\end{array}$ & to & $\begin{array}{l}4-1 \\
(301)\end{array}$ & G \\
\hline B Staurosphaera glebulosa & & & & - & $\begin{array}{l}5, \mathrm{CC} \\
(361) \\
\end{array}$ & to & $\begin{array}{l}4-1 \\
(301) \\
\end{array}$ & G \\
\hline B Staurosphaera septemporata & & & Below & $\begin{array}{l}\begin{array}{l}\text { B-2, CC } \\
(361)\end{array} \\
\end{array}$ & \begin{tabular}{|l|}
$5, \mathrm{CC}$ \\
$(361)$ \\
\end{tabular} & to & $\begin{array}{l}4-1 \\
(301)\end{array}$ & G \\
\hline B Dictyomitra (?) lacrimula & Below & $\begin{array}{l}5, C C \mathrm{C} \\
(247)\end{array}$ & Below & $\begin{array}{l}\begin{array}{l}\text { B-2, CC P } \\
(361)\end{array} \\
\end{array}$ & \begin{tabular}{|l} 
3-1, no. 2 \\
$(197)$
\end{tabular} & to & $\begin{array}{l}3-1, \text { no. } \\
(197)\end{array}$ & \\
\hline B Eucyrtis zhamoidai & Below & $\begin{array}{l}5, \mathrm{CC} \text { G } \\
(247)\end{array}$ & Below & $\begin{array}{l}\begin{array}{l}\text { B-2, CC G } \\
(361)\end{array} \\
\end{array}$ & \begin{tabular}{|l|}
$5, \mathrm{CC}$ \\
$(361)$ \\
\end{tabular} & to & $\begin{array}{l}4-1 \\
(301) \\
\end{array}$ & G \\
\hline B Sethocapsa trachyostraca & & & Below & $\begin{array}{l}\begin{array}{l}\text { B-2, CC G } \\
(361)\end{array} \\
\end{array}$ & \begin{tabular}{|l|}
$5, \mathrm{CC}$ \\
$(361)$ \\
\end{tabular} & to & $\begin{array}{l}4-1 \\
(301) \\
\end{array}$ & G \\
\hline T Dibolachras apletopora & & & & - & $\begin{array}{l}5, \mathrm{CC} \\
(361)\end{array}$ & to & $\begin{array}{l}4-1 \\
(301)\end{array}$ & G \\
\hline T Podocapsa amphitreptera & & & & - & $\begin{array}{l}5, \mathrm{CC} \\
(361) \\
\end{array}$ & to & $\begin{array}{l}4-1 \\
(301)\end{array}$ & G \\
\hline T Sethocapsa cetia & & & & - & $\begin{array}{l}5, \mathrm{CC} \\
(361) \\
\end{array}$ & to & $\begin{array}{l}4-1 \\
(301)\end{array}$ & G \\
\hline $\mathrm{T}$ Emiluvia pessagnoi & & & & - & $\begin{array}{l}5, \mathrm{CC} \\
(361) \\
\end{array}$ & to & $\begin{array}{l}4-1 \\
(301)\end{array}$ & G \\
\hline $\mathrm{T}$ Triactoma tithonianum & & & & - & $\begin{array}{l}5, \mathrm{CC} \\
(361)\end{array}$ & to & $\begin{array}{l}4-1 \\
(301)\end{array}$ & G \\
\hline
\end{tabular}


TABLE 4 - Continued

\begin{tabular}{|c|c|c|c|c|c|c|c|c|}
\hline \multirow[b]{2}{*}{ B } & \multirow[b]{2}{*}{ Paronaella (?) diamphidia } & \multicolumn{2}{|c|}{ Hole 194} & \multicolumn{2}{|c|}{ Hole 195 and $195 \mathrm{~B}$} & \multicolumn{2}{|c|}{ Hole 196} & \multirow[b]{2}{*}{ G } \\
\hline & & & & $\begin{array}{l}5, \mathrm{CB} \text { t } \\
(278-310\end{array}$ & $\begin{array}{l}\text { to } 4, \text { CC P } \\
\text { j) }(272)\end{array}$ & Below & $\begin{array}{l}5, \mathrm{CC} \\
(361)\end{array}$ & \\
\hline B & Dictyomitra carpatica (?) & Below & $\begin{array}{l}5, \text { CC G } \\
(247)\end{array}$ & \begin{tabular}{|l|}
$\begin{array}{l}\text { B-1, CC } \\
(357)\end{array}$ \\
\end{tabular} & $\begin{array}{l}\text { to 5, CB P } \\
(278-310)\end{array}$ & Below & $\begin{array}{l}5, \mathrm{CC} \\
(361)\end{array}$ & G \\
\hline B & Acaeniotyle diaphorogona & Below & $\begin{array}{l}5, C C \mathrm{G} \\
(247)\end{array}$ & Below & $\begin{array}{l}\text { B-2, CC G } \\
(361)\end{array}$ & Below & $\begin{array}{l}5, \mathrm{CC} \\
(361)\end{array}$ & M \\
\hline B & Acanthocircus trizonalis (?) & Below & $\begin{array}{l}5, \text { CC G } \\
(247)\end{array}$ & Below & $\begin{array}{l}\begin{array}{l}\text { B-2, CC G } \\
(361)\end{array} \\
\end{array}$ & Below & $\begin{array}{l}5, \mathrm{CC} \\
(361) \\
\end{array}$ & G \\
\hline B & Acaeniotyle umbilicata & Below & $\begin{array}{l}5, \text { CC G } \\
(247)\end{array}$ & Below & $\begin{array}{l}\begin{array}{l}\text { B-2, CC G } \\
(361)\end{array} \\
\end{array}$ & Below & $\begin{array}{l}5, \mathrm{CC} \\
(361)\end{array}$ & G \\
\hline B & Sphaerostylus lanceola & Below & $\begin{array}{l}5, \mathrm{CC} \mathrm{G} \\
(247)\end{array}$ & Below & $\begin{array}{l}\text { B-2, CC G } \\
(361)\end{array}$ & Below & $\begin{array}{l}5, \mathrm{CC} \\
(361)\end{array}$ & G \\
\hline B & Podobursa (?) polylophia & & & Below & $\begin{array}{l}\begin{array}{l}\text { B-2, CC G } \\
(361)\end{array} \\
\end{array}$ & Below & $\begin{array}{l}5, \mathrm{CC} \\
(361)\end{array}$ & G \\
\hline B & Podobursa triacantha & & & Below & $\begin{array}{l}\begin{array}{l}\text { B-2, CC G } \\
(361)\end{array} \\
\end{array}$ & Below & $\begin{array}{l}5, \mathrm{CC} \\
(361)\end{array}$ & G \\
\hline & Syringocapsa limatum & & & Below & $\begin{array}{l}\text { B-2, CC G } \\
(361)\end{array}$ & Below & $\begin{array}{l}5, \mathrm{CC} \\
(361)\end{array}$ & G \\
\hline B & Acanthocircus dizonius & & & Below & $\begin{array}{l}\text { B-2, CC G } \\
(361)\end{array}$ & Below & $\begin{array}{l}5, \mathrm{CC} \\
(361)\end{array}$ & G \\
\hline & Stichocapsa (?) rotunda & & & Below & $\begin{array}{l}\begin{array}{l}\text { B-2, CC G } \\
(361)\end{array} \\
\end{array}$ & Below & $\begin{array}{l}5, \mathrm{CC} \\
(361) \\
\end{array}$ & G \\
\hline & Sethocapsa leiostraca & & & Below & $\begin{array}{l}\begin{array}{l}\text { B-2, CC G } \\
(361)\end{array} \\
\end{array}$ & Below & $\begin{array}{l}5, \mathrm{CC} \\
(361)\end{array}$ & G \\
\hline & Dictyomitra cosmoconica & & & Below & $\begin{array}{l}\text { B-2, CC G } \\
(361)\end{array}$ & Below & $\begin{array}{l}5, \mathrm{CC} \\
(361)\end{array}$ & G \\
\hline B & Podobursa tetracola & & & Below & $\begin{array}{l}\begin{array}{l}\text { B-2, CC G } \\
(361)\end{array} \\
\end{array}$ & Below & $\begin{array}{l}5, \mathrm{CC} \\
(361) \\
\end{array}$ & G \\
\hline & Emiluvia chica & & & & - & Below & $\begin{array}{l}5, \mathrm{CC} \\
(361) \\
\end{array}$ & G \\
\hline B & Dibolachras apletopora & & & & - & Below & $\begin{array}{l}5, \mathrm{CC} \\
(361) \\
\end{array}$ & G \\
\hline B & Podocapsa amphitreptera & & & & - & Below & $\begin{array}{l}5, \mathrm{CC} \\
(361) \\
\end{array}$ & G \\
\hline & Sethocapsa cetia & & & & - & Below & $\begin{array}{l}5, \mathrm{CC} \\
(361) \\
\end{array}$ & G \\
\hline B & Emiluvia pessagnoi & & & & - & Below & $\begin{array}{l}5, \mathrm{CC} \\
(361)\end{array}$ & G \\
\hline & Triactoma tithonianum & & & & - & Below & $\begin{array}{l}5, \mathrm{CC} \\
(361)\end{array}$ & G \\
\hline
\end{tabular}

Note: See text for an explanation of symbols.

known described and undescribed forms from Late Cretaceous sediments. The fauna is illustrated on Plate 14, and a few of the species are treated briefly in the taxonomic section where the age of the related forms is given. A Late Cretaceous, possibly Cenomanian, age is assigned to this sample on the basis of the age of related forms.

From 195-4, CC (272-278 meters below the sediment surface) two chert samples were examined, a dark reddish brown chert which contains only a few very poor Radiolaria and a sample of pink chert with common poor Radiolaria. The fauna is considered to belong to the Acaeniotyle tribulosa assemblage. Since the sample is dated Valanginian-early Hauterivian on the basis of nannofossils, it is possible to consider its age as near the top of this range.

The center bit sample before attempted Core 5, which may contain sediments from 278 to 310 meters below the sediment surface, has a few moderate to very poorly preserved Radiolaria; the variability in the preservation suggests mixing. Besides the presence of many of the forms recognized in 195-4, CC, numerous forms present in the older samples from Hole 196 are also present, and the sample is considered to be near the top of the Sethocapsa trachyostraca assemblage range, Valanginian-Early Hauterivian according to nannofossils.

No core was recovered from Hole 195A. Two samples were examined: one from the center bit before Core 1 was attempted and the other scrapings from the drill bit at a total depth of 6351 meters ( 383 meters below the sediment surface). The center bit contained rare moderately to poorly preserved Radiolaria, probably mixed, and probably Cretaceous in age. The bit sample contained a few well-preserved Quaternary and Neogene Radiolaria, 


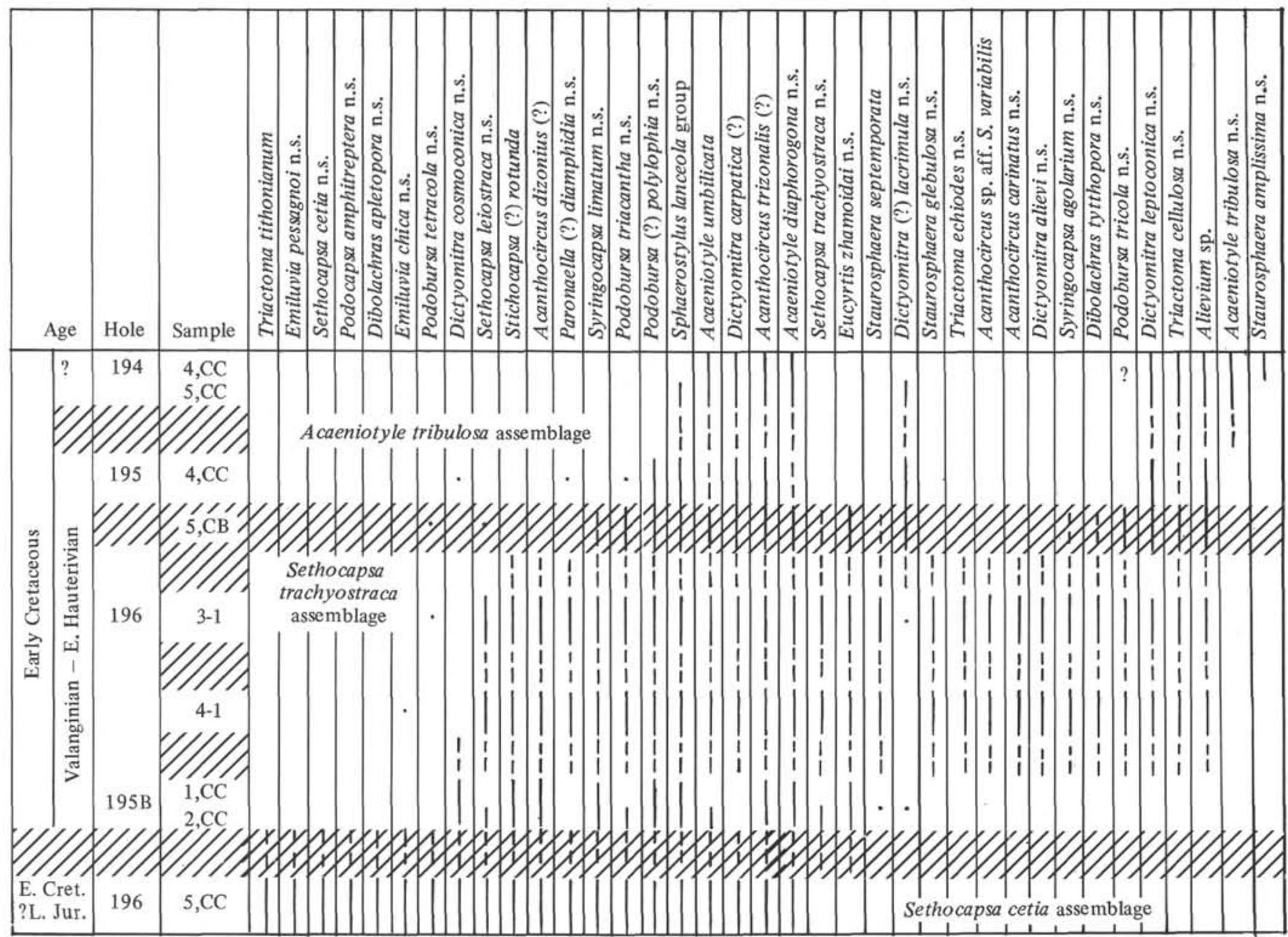

Figure 1. Range chart for Early Cretaceous - ? Late Jurassic Radiolaria from Holes 194, 195, 195B and 196. See text for an explanation of symbols.

obviously the result of downhole contamination, and a few Early Cretaceous Radiolaria, Syringocapsa limatum, Sethocapsa trachyostraca, and Sethocapsa leiostraca. It is considered to be near the base of the Sethocapsa trachyostraca assemblage range, Valanginian-early Hauterivian age according to nannofossils. No Paleogene Radiolaria were observed among the contaminants.

From Hole 195B, Cores 1 and 2 (at depths of 357.5-367 meters and 367-371 meters below the sediment surface, respectively) had recovery of core catcher samples only. The presence of only one specimen of Staurosphaera septemporata, together with the presence of Sethocapsa trachyostraca, Syringocapsa limatum, and Dictyomitra cosmoconica, indicates the samples are near the base of the Sethocapsa trachyostraca assemblage range and suggests that these two samples are intermediate in age between 196-4 (Valanginian-early Hauterivian on the basis of nannofossils) and 196-5, CC (Early Cretaceous-?Late Jurassic). According to nannofossils, the maximum age is Valanginian.

Only a few very poor indeterminate Radiolaria, among them pyritized members of the Sphaerostylus lanceola group, were recovered from the core catcher of Core 3 at a total depth of 6360 meters (389-392 meters below the sediment surface), and no age determination can be made.

Thus at Site 195, two distinct Early Cretaceous radiolarian faunas can be recognized: in 195-4 is a fauna belonging to the Acaeniotyle tribulosa assemblage and in $195 \mathrm{~A}-1$ bit sample, 195B-1, and $195 \mathrm{~B}-2$ is a fauna belonging to the Sethocapsa trachyostraca assemblage.

\section{Radiolaria from Hole 196}

Radiolaria are present in all of the six cores recovered from this site (Table 3). Nannofossils are found in Cores 3, 4 , and 6 , and foraminifera in Core 2 only.

\section{Cenozoic Radiolaria}

Radiolaria are few and well preserved in Core 1 (at 37.5-47 meters below the sediment surface). Of the species listed by Hays (1970) in his zonation of the north Pacific Pleistocene and Pliocene, those listed by Nigrini (1971) in her zonation of the Quaternary of the equatorial Pacific, and those listed or illustrated by Riedel and Sanfilippo $(1970,1971)$ in their zonation of the Pleistocene and Pliocene of the tropical Atlantic and Pacific, only two species, Eucyrtidium tumidulum Bailey $(1856)=$ Arto- 
strobium miralestense (Campbell and Clark) and Lithopera bacca, were recognized. Both range from Recent to mid Miocene. The presence of $E$. tumidulum subsequent to the extinction of Stylatractus universus is defined as the $E$. tumidulum Zone. This zone spans the last 400,000 years and is, according to Hays (1970), equivalent to $\Omega$ Zone of Hays (1965) and N.23 of Blow (1969). However, because of the absence of cooccurring restricted Quaternary forms, except one specimen of an oblong form of Spongaster tetras (a cool-water form of Spongaster tetras tetras), and because of the depth of the sample ( 37.5 meters below the sediment surface), it is not considered likely that this sample belongs to the E. tumidulum Zone, and it is tentatively identified only as Quaternary.

Core 6 (at a total depth of 6571 meters) contains red clay from near the top of the hole and chips of chert and limestone from the bottom of the hole. The contaminant red clay contains an abundant well-preserved Quaternary radiolarian fauna.

\section{Mesozoic Radiolaria}

Cores 2 through 6 , from 104-370 meters below the sediment surface, contain rare poor to common moderately well preserved Radiolaria. Three distinct assemblages could be recognized.

In Core 2 (104-110 meters below the sediment surface), Radiolaria are lacking in Sections 1 and 2. They are poorly preserved and rare to few in Sections 3,5, and 6, and the core catcher, and poorly preserved and common in Section 4. The presence of Dictyomitra torquata, total range not established but known from a number of Campanian localities, suggests a similar age for this fauna. In addition, the presence of a number of specimens similar to Dictyomitra sp. (Foreman, 1971, pl. 3, fig. 5) and Rhopalosyringium sp. (Foreman, 1971, pl. 3, fig. 9), both also known from Campanian localities, tends to confirm this age assignment.

Samples $3-1$, pieces 1,2 , and 3 , and $4-1$, piece 3 (197-203 and 300.5-310 meters below the sediment surface, respectively) contain common moderately well preserved Radiolaria. The assemblages in these two cores are similar. They contain many of the species found in 195A-1, bit sample and 195B-1, CC and 2, CC and are considered to belong to the Sethocapsa trachyostraca assemblage. The samples from Cores 3 and 4, particularly, have many elements in common with an assemblage described by Fischli (1916) from flint of a molasse conglomerate of the Rigi in Switzerland, considered by him to be of probable Lower Cretaceous age. They also contain some of the species illustrated by Pessagno (1969) from DSDP 1-5A-7-11: Spongosaturnalis dicranacanthos $=$ Acanthocircus dizonius Rüst (?); Spumellariinid (pl. 4, fig. $\mathrm{N}$ ) = Acaeniotyle umbilicata; and undescribed Spumellariinid (pl. 4 , fig. D) $=$ member of Sphaerostylus lanceola group, considered to be Upper Jurassic (Tithonian) on the basis of nannofossils (Bukry and Bramlette, 1969). However, a reevaluation of the nannofossil assemblage by Worsley (1971) suggests that the sample is Berriasian-Valanginian. Also present are Staurosphaera septemporata Parona, reported from the Hauterivian-Barremian by Cita and Pasquaré (1959), and common members of the genus
Podobursa Wiśniowski (1889, sense as it is emended in this report). Two unnamed species apparently belonging to this genus are illustrated by Lozyniak (1969, pl. 1, figs. 4 and 6) from sediments he considers to be Neocomian in age. These common elements form the basis for considering the Sethocapsa trachyostraca assemblage to be Neocomian in age. On the basis of the nannofossils of Leg 20,196-3-1, pieces 1,2, and 3, and 196-4-1, piece 3 are considered to be Valanginian-early Hauterivian.

Sample 196-5, CC (360.5-370 meters below the sediment surface) contains some of the forms observed in 195A-1, bit sample; 195B-1; 195B-2; 196-3; and 196-4 and in addition some species (Triactoma tithonianum, Emiluvia pessagnoi, and an unusually large form Sethocapsa cetia) restricted to this sample. 196-5, CC contains the oldest Radiolaria recovered on Leg 20, belonging to the Sethocapsa cetia assemblage which distinguishes it easily from the Sethocapsa trachyostraca assemblage of 196-3 and 196-4 and is considered to be Early Cretaceous-?Late Jurassic in age.

Sample 196-6, CC contains, besides the contaminated Quaternary radiolarian fauna from the top of the hole, contaminated Mesozoic Radiolaria from above 196-5, CC.

Thus at Site 196, three distinct Cretaceous radiolarian assemblages can be recognized: 196-2, Late Cretaceous (Campanian); 196-3 and 196-4, Early Cretaceous (Valanginian-Early Hauterivian according to nannofossils) Sethocapsa trachyostraca assemblage; and 196-5, Early Cretaceous-?Late Jurassic Sethocapsa cetia assemblage.

\section{Radiolaria from Hole 198A}

Radiolaria are present in varying amounts in Cores 2, 3, 4 , and 5 (100-134.5 meters below the sediment surrace) and in the bit sample at a total depth of 6116 meters (258 meters below the sediment surface). They are all poorly preserved except for rare well-preserved Radiolaria in Core 5 . Foraminifera are rare and poorly preserved throughout Core 3 and in Sections 1 through 3 of Core 4. Nannofossils are entirely lacking.

Radiolaria in Cores 2, 3, and Core 4, Sections 1 through $4,25-27 \mathrm{~cm}$, are too rare and poor to make an age determination other than Late Cretaceous on the basis of the probable early Campanian age of the abundant Radiolaria in the remainder of Core 4 and the rare Radiolaria of the core catcher of Core 5. Radiolaria common to Core 4 and Core 5 are Dictyomitra torquata, Amphipyndax enesseffi, Artostrobium urna, and Theocampe salillum. These are illustrated on Plate 16 together with a variety of Saturnalians and some common as yet unnamed species.

The bit sample of attempted Core 6 yielded common poorly preserved Radiolaria. The oldest identifiable species, Stichocapsa (?) rotunda, Dictyomitra leptoconica, and Syringocapsa agolarium, suggest an association with the Sethocapsa trachyostraca assemblage.

\section{Radiolaria from Hole 199}

In Hole 199, Core 3 contained very rare, poor Radiolaria, Cyrtocapsella cornuta, Stichocorys delmontensis, and $S$. wolffii, indicating an early to middle Miocene age. Abundant well-preserved Radiolaria are present only in Core 5 . They are predominantly Oligocene with the 
Dorcadospyris ateuchus Zone being the youngest zone represented. Also present are well-preserved, reworked Radiolaria known to range from the late Paleocene (P.5) through the middle Eocene. Late Eocene and early Oligocene Radiolaria are lacking. The youngest forms must also be considered reworked because of the very rare, poorly preserved younger Radiolaria in Core 6, Stichocorys delmontensis and $S$. wolffii, which indicate an early to middle Miocene age.

\section{STRATIGRAPHIC RESULTS}

The Early Cretaceous samples recovered from Sites 194, 195 , and 196 are too few and too poorly preserved to allow the definition of formal zones.

However, because so little is known of the stratigraphic sequence of Radiolaria in this part of the geologic column, it seems useful to define at least three informal assemblages which may serve as a basis, when more material is available, to define more formal zones. These informal assemblages are in order from oldest to youngest.

Sethocapsa cetia assemblage: This assemblage is based on one sample only and represents the oldest material recovered. It is characterized by the presence of Triactoma tithonianum, Emiluvia pessagnoi, E. chica, Podocapsa amphitreptera, and Sethocapsa cetia.

Sethocapsa trachyostraca assemblage: Cooccurring with Sethocapsa trachyostraca are: Staurosphaera septemporata, Acanthocircus dizonius (?), A. carinatus, Triactoma echiodes, Dictyomitra alievi, Syringocapsa agolarium, and Dibolachras tytthopora.

Acaeniotyle tribulosa assemblage: This assemblage is less well defined than the preceding two because of the paucity of recognizable forms and poor preservation. There is the possibility, therefore, that absences from the samples on which this assemblage is based may be due to these factors rather than to evolutionary change. Cooccurring with Acaeniotyle tribulosa are Staurosphaera amplissima and common Dictyomitra (?) lacrimula. Of interest is the presence of only rare members of the subfamily Syringocapsinae. Of the 12 species present in the next older assemblage, only 3 are present here, and all are rare or represented by isolated specimens only.

Examination of the early literature concerning Mesozoic Radiolaria (i.e., Rüst, 1885, 1898, Parona, 1890, and Neviani, 1900 who all describe Jurassic Radiolaria) would suggest that the radiolarian fauna here assigned to the Early Cretaceous is actually Jurassic in age. Similarities in the fauna studied here and the species in the early literature include the presence of: Staurosphaera septemporata Parona, (1890); members of the genus Podobursa Wiśniowski (1889, sense as it is emended in this report) which are commonly illustrated by Rüst (1885), Parona (1890), and Heitzer (1930), to name but a few; and the presence of peculiar elliptical saturnalin rings with distinctive broadened saddle-like ends reported by Rüst (1885) and Squinabol (1914). All are described from sediments of Jurassic age by their authors. In contrast to this are more recent reports: Fischli (1916, Early Cretaceous), Cita and Pasquaré (1959, HauterivianBarremian), Lozyniak (1969, Neocomian), and Pessagno (1969, Tithonian, according to Bukry and Bramlette, 1969 or Berriasian-Valanginian according to Worsley, 1971). All describe faunas containing one or more of the elements mentioned above, and it is on the basis of these later age assignments that the Radiolaria of the Sethocapsa trachyostraca assemblage are considered to be Neocomian in age. On the basis of nannofossils the age is considered to be Valanginian-early Hauterivian. Cores with Radiolaria from the $S$. trachyostraca assemblage are: 195-5, CB, 195A-1, 195B-1, 195B-2, 196-3, and 196-4.

The oldest sample, 196-5, CC, on the other hand, while containing a fauna with some of the elements described above, differs markedly in containing numerous forms present only here. This fauna defines the Sethocapsa cetia assemblage and on the basis of Radiolaria is considered to be Neocomian-?Late Jurassic in age. Calcareous fossils do not cooccur.

Of the youngest Early Cretaceous samples, 194-4, CC, 194-5, CC, and 195-4, CC, only the latter cooccurs with calcareous fossils and is on that basis considered to be Valanginian-early Hauterivian in age. These samples contain fewer and more poorly preserved Radiolaria. This fauna defines the Acaeniotyle tribulosa assemblage and is considered to be Early Cretaceous.

\section{RADIOLARIAN RANGES AND EVENTS}

From the information in Tables 1 through 3 a list (Table 4) has been made which gives the events (i.e., the first and last appearance of each taxon) in chronological order from youngest to oldest. The core samples between which an event takes place and the corresponding depth in meters below the surface are given for each event in each hole. Thus, this list serves to correlate the events in detail from hole to hole. Ideally, these events should progress downward in each hole with correlation lines parallel and without any crossing of lines. Unfortunately, this is not the case. The crossing of a number of correlation lines serves to emphasize the difficulty in correlating, except in a very general way, between holes when samples are few and the fauna is frequently either poorly preserved or sparse. Most of the crossed lines are certainly due to the poor preservation and paucity of recognizable forms in some of the samples. When lines cross, the determining factor in placing the event is its reliability, indicated by: $G$, good; $M$, moderate; and $P$, poor. Reliability criteria are based on the abundance of Radiolaria in a sample, the quality of preservation, and the certainty of identification. Two other abbreviations, $T$, top of a taxon and $B$, base of a taxon, are used.

The range chart (Figure 1) records the ranges of species as determined from the list of events (Table 4) for Holes 194, 195, 195B, and 196 and serves to define the three informal assemblages. Because no long sequénce of samples was available from any one hole, the chart is a composite of samples from these four holes.

The center bit sample (195-5, CB) is included because it contains the best preserved and the oldest Lower Cretaceous Radiolaria in Hole 195. It is represented on the range chart as a hachured area of uncertainty because occurrences in that sample may come from any level within the thirty-two meters of sediment between Core 4 and attempted Core 5 . Range lines for species with the top of 
their range within this sample are shown as dashed lines because of the uncertainty as to the level of their last appearance within this sample. It is evident from the presence of a number of well-preserved species that occur only in this sample that there is downward contamination. None of the described species present in the younger samples has the base of its range in 195-5, CB.

There are a number of species with their last or initial occurrence represented by a dot, indicating an isolated single occurrence. While some of these isolated occurrences (those in Samples 196-3-1 and 196-4-1) probably do represent isolated last or initial appearances, the other isolated occurrences may just as likely be due to poor preservation or general paucity of forms, and therefore the actual range of the species may be greater than indicated. Isolated occurrences that are bracketed by more common occurrences are not indicated by dots.

\section{SYSTEMATIC PALEONTOLOGY}

\section{Suborder SPUMELLARIA Ehrenberg, 1875}

Family ACTINOMMIDAE Haeckel, emend. Riedel, 1967

\section{ACAENIOTYLE Foreman, new genus}

Type species: Xiphosphaera umbilicata Rüst, 1898.

Definition: Spherical or ellipsoidal shell with a surface of large porous nodes from which two or three spines extend.

Etymology: Greek akainos thorny + tyle f. pillow = Acaeniotyle f. thorny pillow.

\section{Acaeniotyle diaphorogona Foreman, new species} (Plate 2, Figures 2-5)

Description: The nodose shell, circular in transverse section and elliptical in vertical section, bears three sturdy three-bladed spines with blunt tips. The spines are approximately equal in length in the older forms and longer, less equal in the younger forms; some show a slight tendency to turn. They are arranged asymmetrically with angles between adjacent spines approximately $90^{\circ}, 115^{\circ}$, and $155^{\circ}$, respectively. Pores are closely spaced, circular to subangular, and moderate in size. The interior of the shell could not be examined and it is not certain if there are any internal structures.

Measurements based on 20 specimens from 196-5, CC, 196-4-1, piece 3, 196-3-1, pieces 3 and 1 , and 194-4, CC. Diameter of shell, $110-195 \mu$ (majority $125-170 \mu$ ); length of spines, $75-185 \mu$ (majority 95-140 $\mu$ ).

Remarks: Excluded are forms with spines more symmetrically arranged (Plate 16, Figure 16) and forms with proportionately longer, more slender spines (Plate 2, Figures 6 and 7).

This species is distinguished from the younger Acaeniotyle tribulosa by the greater length of the three spines, the asymmetric arrangement, and the general lack of basal pores.

Etymology: Greek diaphoros different + gonia f. angle $=$ diaphorogonus, $-a,-u m$, with different angles.

\section{Acaeniotyle tribulosa Foreman, new species (Plate 2, Figure 8)}

Description: The nodose shell is large, spherical or slightly flattened in the plane of its three short three-bladed spines. The spines are equal in length, equally disposed, and have three large pores between adjacent blades at the base of each spine. Pores of the shell are closely spaced, circular to subangular, and moderate in size. The interior of the shell could not be examined and it is not certain if there are any internal structures.

Measurements (based on five specimens from 194-5, CC and $194-4$, CC). Diameter of shell, $170-185 \mu$; length of arms, 50-90 $\mu$.
Remarks: Although very rare, this form is described because it is distinctive, easily recognizable, and representative of strata younger than 195-4, CC, and 196-3-1, piece 1 .

It is distinguished from all other nodose forms with three-bladed spines by its large size and relatively short spines of equal length with basal pores.

Etymology: Latin tribulosus, - $a,-u m$ three pronged.

\section{Acaeniotyle umbilicata (Rust)}

(Plate 1, Figures 12-14, 16)

Xiphosphaera umbilicata Rust, 1898, p. 7, pl. 1, fig. 9.

Description: The nodose shell is almost spherical, very slightly flattened so that its largest dimension is in the equatorial plane. It bears two three-bladed polar spines, unequal in length. Rare specimens have spines which turn slightly. Pores of the shell are closely spaced, circular to subangular, and moderate in size. The interior of the shell could not be examined and it is not certain if there are any internal structures.

Measurements (based on 25 specimens from 196-5, CC, 196-4-1, piece $3,196-3-1$, pieces 3 and 1 , and 194-5, CC). Length of long spine, $105-250 \mu$; of short spine, $80-190 \mu$; diameter of shell in plane of polar spines, $110-205 \mu$; in equatorial plane, $125-215 \mu$.

Remarks: The specimens described above agree very well with Rust's description of Xiphosphaera umbilicata. They differ only in that the polar spines are rarely equal in length and are not as long as those described by Rust. $X$. umbilicata is reported from the Upper Jurassic of Cittiglio in northern Italy.

Specimens with very large shells $(200-215 \mu$ in diameter) and the rare specimens with turned spines were found only in the younger samples.

Not included is a rare, very large form with long, very sturdy spines occurring only in the younger samples (Plate 1, Figure 15).

\section{Genus SPHAEROSTYLUS Haeckel, 1881}

Sphaerostylus Haeckel, 1881, p. 451. Type species (by subsequent monotypy) Sphaerostylus zittelii Rust, 1885.

\section{Sphaerostylus lanceola (Parona) group}

(Plate 1, Figures 7-11)

Stylosphaera lanceola Parona, 1890, p. 150, pl. 1, fig. 19.

Stylosphaera sp. Parona, 1890, p. 150, pl. 1, fig. 18; Zhamoida in Dundo and Zhamoida, 1963, pl. 1, fig. 9; Kling, 1971, p. 1089, pl. 10 , fig. 3 .

Lithatractus sp. Parona and Rovereto, 1895, p. 175, fig. 27, non fig. 28.

Xiphostylus felsinae Neviani, 1900 , p. 649 , pl. 9, fig. 7 .

[?] Xiphosphaera manzonii Neviani, 1900 , p. 648, pl. 9 , fig. 5 .

Stylatractus ovatus Hinde, 1900, p. 19, pl. 4, figs. 29, 31-33, 36.

Stylatractus paronae Hinde, 1900 , p. 18, pl. 4, fig. 34.

[?] Stylatractus tener Hinde, 1900, p. 18, pl. 4, fig. 35.

Stylosphaera squinaboli Tan Sin Hok, 1927, p. 35, pl. 6, figs. 9a-d.

? Meyenella hensoni Davis, 1950, p. 213, pl. 7, figs. 11, 12 .

Radiolarian [Gen. and sp. indet.] Turner, 1965, p. 394, pl. 52, figs. 14,15 .

[?] Spumellarian [Gen. and sp. indet.] Pessagno, 1969, p. 610, pl. 4 , fig. D.

[?] Protoxiphotractus (?) fischeri Pessagno (in press).

Description: The shell is spherical to slightly ellipsoidal with two opposing three-bladed polar spines of unequal length. Rarely, a small spherical internal lattice shell can be discerned. Because preservation is generally poor it is not certain if this internal shell is a constant feature or, indeed, if it is present at all in the early members of the group. If the outer shell is not spherical, its greatest dimension is generally in the plane of the two opposing polar spines. Pores are large, pentagonal to hexagonal, 7 to 10 per circumference, and the shell wall is thick. The surface is smooth or slightly nodular where the intervening pore bars join.

Measurements (based on 80 specimens from 196-5, CC; 196-4-1, piece $3 ; 196-3-1$, piece $3 ; 195 \mathrm{~B}-2$, CC; $195 \mathrm{~B}-1$, CC; 195-5, CB; 195-4, CB; and Ser. VIII 150, Tan Sin Hok, 1927). Width of shell in polar plane, $70-135 \mu$ (majority $75-110 \mu$ ); in equatorial plane, $70-130 \mu$ (majority $75-110 \mu$ ); of inner shell (based on 4 specimens only), $20-30 \mu$; length of long polar spine, $60-150 \mu$; of short polar spine, $25-100 \mu$. 
Remarks: Early forms tend to be small and delicate with a more ellipsoidal shell and spines very slightly turned, while the youngest forms are more massive with a more spherical shell. However, considerable gradation exists throughout the range of this group, and no attempt is made now to separate the forms from various levels on the basis of size and shape. The table below gives the range of size for 10 specimens from the oldest and 10 from the youngest samples considered.

Ser. VIII 150

196-5, CC (Tan Sin Hok, 1927)

E.Cret.-?L.Jur. Turon. or E. Senon.

Width:

Outer shell in polar plane

$75-100 \mu$

$95-135 \mu$

Outer shell in equatorial plane

Inner shell

$70-100 \mu$

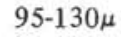

Length:

$\begin{array}{lll}\text { Long polar spine } & 45-115 \mu & 90-120 \mu \\ \text { Short polar spine } & 25-75 \mu & 50-95 \mu\end{array}$

Xiphosphaera manzonii, Stylatractus tener and Protoxiphotractus (?) fischeri $=[\mathrm{Gen}$. and sp. indet.] Pessagno, are only doubtfully included in the group because the polar spines differ. The former two are illustrated with long, slender, smooth, spines, and the spines of the latter are described as having four blades, although this is not evident in the illustration.

Stylosphaera lanceola and Stylosphaera sp. Parona are both reported from the Upper Jurassic of Cittiglio, northern Italy; Stylosphaera sp. Zhamoida from the Valanginian of the Koryaksk Highland, USSR; Stylosphaera sp. Kling from the probable Early Cretaceous of the Shatsky Rise, DSDP Leg 6; Lithatractus sp. Parona and Rovereto from the Permian [?] of western Liguria, northern Italy, probably Jurassic according to Squinabol (1913); Xiphostylus felsinae from the Tithonian of Grizzana, Italy; Xiphosphaera manzonii from the Tithonian of Savignano, Italy; Stylatractus ovatus, $S$. paronae, and $S$. tener from the probable Jurassic or possible Lower Cretaceous of Central Borneo; Stylosphaera squinaboli from the Turonian or early Senonian of Roti; ?Meyenella hensoni from the Jurassic of Syria; Radiolarian [Gen. and sp. indet.] Turner from the Berriasian of the Hautes-Alpes, France; and Protoxiphotractus (?) fischeri $=[\mathrm{Gen}$. and sp. indet.] Pessagno from the Tithonian or BerriasianValanginian of the Blake Bahama Basin, DSDP Leg 1.

\section{Genus STAUROSPHAERA Haeckel, 1881}

Staurosphaera Haeckel, 1881, p. 450. Type species (by subsequent monotypy) Staurosphaera crassa Dunikowski, 1882, p. 187, pl. 5 , fig. 52.

Remarks: The species assigned to this genus probably represent many different phylogenetic lineages. Grouped here are all the Mesozoic forms, exclusive of the Pseudoaulophacidae, with four main spines disposed in a cross, regardless of the nature of the shell (porous or spongy), the shape of the shell (spherical, ellipsoidal, or rectangular), or the length of the spines. It is not possible in most cases in this material to determine if more than one shell is present.

\section{Staurosphaera amplissima Foreman, new species (Plate 3, Figure 6)}

Description: The shell is large, subrectangular to subcircular in transverse section and elliptical in vertical section. Four sturdy, long, unequal in length, three-bladed spines are equally disposed to form a cross. Pores are large, rounded and fairly regular. In some specimens they appear to be scalloped or subdivided into smaller pores on their lower margin.

Measurements (based on 10 specimens from 194-4, CC). Greatest width of shell, $185-210 \mu$; of spines near their base, $30-50 \mu$; diameter of pores, 15-20 $\mu$; length of spines, $200-310 \mu$.

Remarks: This distinctive form is easily differentiated from other staurosphaerids in the material studied by its large robust form. In the geologic record, species of the genus Staurosphaera are described from numerous levels. Many species are superficially similar. Therefore, to distinguish them, one must consider, in addition to the descriptions, the associated species and the level at which they are found.

Etymology: Latin amplissimus, $-a,-u m$ very large.

\section{Staurosphaera glebulosa Foreman, new species}

(Plate 3, Figure 5; Plate 16, Figure 24)

Description: The shell is small, circular in transverse section, elliptical in vertical section, and bears four relatively sturdy, three-bladed spines. Three of these spines are approximately equal in length and one is longer. The surface of the shell is slightly nodose and has small, rounded, somewhat irregular, closely spaced pores.

Measurements (based on 13 specimens from 196-4-1, piece 3 and 196-3-1, pieces 3 and 2). Greatest width of shell, $95-124 \mu$ (majority 95-115 $\mu$ ); length of short spines, 80-150 $\mu$; of long spine $115-180 \mu$.

Remarks: The older forms in Sample 196-4-1, piece 3 tend to have an only slightly nodose surface with smaller, more irregular pores, while the younger forms in Samples 196-3-1, pieces 3 and 2 have a more nodose surface with larger, more regular pores.

Etymology: Latin glebula f. dim. lump + osus full of = glebulosus, - $a$, - um full of lumps.

\section{Staurosphaera septemporata Parona (Plate 3, Figure 4)}

Staurosphaera septemporata Parona, 1890, p. 151, pl. 2, figs. 4, 5; Cita and Pasquare, 1959 , p. 398 , fig. 3 , no. 7.

Staurolonche robusta Rust in Fischli, 1916, fig. 36 (not Rust, 1885, pl. 29, fig. 2.)

[?] Staurolonche sp. Fischli, 1916, fig. 37.

Description: Shell spherical with four sturdy, three-bladed, pointed spines at right angles to each other. These generally differ in their length, the opposing pair of polar spines long but unequal to each other and the opposing equatorial spines short and approximately equal. Rarely, all four spines are approximately equal in length, and extremely rarely, there are only three spines equally disposed. Pores as for Sphaerostylus lanceola.

Measurements (based on 14 specimens from 196-4-1 and 196-3-1). Width of shell, $85-105 \mu$; length of polar spines, $55-125 \mu$, of lateral spines, $30-90 \mu$.

Remarks: There is some evidence for the presence of a second inner shell; however, preservation makes observation difficult, and as the presence of an inner shell is doubtful, the generic assignment is made on the basis of a form with only one shell. Staurolonche sp. Fischli (1916, fig. 37) is only doubtfully synonomized because no form with such broad-based spines has been observed.

Staurosphaera septemporata is reported from the Upper Jurassic of Cittiglio and the Hauterivian-Barremian of Alpe Puez, both in northern Italy, and Staurolonche robusta Ruist in Fischli from the probable Early Cretaceous of the Rigi in Switzerland.

\section{TRIACTOMA Rüst, 1885}

Triactoma Rúst, 1885 , p. 289 = Triactis Haeckel, 1881, p. 457. Type species (subsequent designation by Campbell, 1954, p. D181) Triactoma tithonianum Rust, 1885.

Remarks: Loeblich and Tappan $(1961$, p. 224) indicate that "Triactoma was apparently used by Rust as a substitute name for Triactis Haeckel, 1881..." However, they validate the use of the name Triactoma because Triactis Haeckel, 1881 is a junior homonym of Triactis Klunzinger, 1877.

Assigned to this genus are all Mesozoic forms with three main spines and a smooth or spiny, porous shell. Excluded are the forms with large nodes, assigned to the genus Acaeniotyle.

Triactoma cellulosa Foreman, new species (Plate 2, Figures 9 and 10; Plate 16, Figure 9)

Description: The shell is small, circular to subtriangular in transverse section, subelliptical to elliptical in vertical section, and 
bears three approximately equal, sturdy, three-bladed spines. The angles between adjacent spines are generally approximately equal but may be more irregular. Pores of the shell are very small, rounded, and closely spaced. The surface of the shell may be slightly roughened with small protrusions.

Measurements (based on 10 specimens from 196-4-1, piece 3 , 196-3-1, pieces 3 and 2 , and $194-4, C C)$. Greatest width of shell, 95-115 $\mu$; length of spines, $100-200 \mu$.

Remarks: Later forms tend to be larger and have more pronounced small protrusions. This species differs from Theodiscus cretaceus Squinabol (1914) in its shorter spines and more closely spaced pores, and from Triactoma echiodes as described under that species.

Etymology: Latin cellulosus, -a,-um full of little cells.

\section{Triactoma echiodes Foreman, new species}

(Plate 3, Figure 1; Plate 16, Figure 21)

Description: The shell is in the shape of a truncate cylinder or drum with the upper and lower surfaces very slightly convex. It bears three sturdy three-bladed spines which extend medianly from the sides. Two of the spines are equal in length and one is generally longer. Angles between adjacent spines are approximately $80^{\circ}, 90^{\circ}$, and $170^{\circ}$. Pores are moderate in size, irregular, circular to subangular, frequently scalloped, and subdivided on their lower margin.

Measurements (based on 10 specimens from 196-4-1, piece 3, and 196-3-1, pieces 2 and 1). Diameter $100-130 \mu$ (majority $125 \mu$ ); height, $120-125 \mu$; length of spines, $125-200 \mu$.

Remarks: The drum-like shape of the shell, together with the three sturdy three-bladed spines arranged as for a staurosphaerid with one spine broken off, distinguish this species from Triactoma cellulosa. A related undescribed form (Plate 3, Figures 2,3) has the same drum-like shape but is smaller with smaller pores, and has its three spines arranged more symmetrically.

Etymology: Greek echion n. drum + odes, -es like = echiodes, -es drum like.

\section{Triactoma tithonianum Rust} (Plate 2, Figure 1)

Triactoma tithonianum Rust, 1885 , p. 289 , pl. 28 , fig. 5 .

Description: The shell is circular to slightly triangular in transverse section, elliptical in vertical section, and bears three slender, delicate, three-bladed spines. No complete spine has been observed; the longest broken spine is equal to the diameter of the shell; its sides are parallel and show no tapering. In the material studied, the spines are almost always broken off very close to their base. Pores are rounded, irregular in size, generally with heavy intervening bars.

Measurements (based on 10 specimens from 196-5, CC). Diameter of shell, $185-200 \mu$; of pores, $12-20 \mu$; width of spines near base, $15-30 \mu$ (majority $15-20 \mu$ ).

Remarks: This species is restricted to $196-5$, CC, the oldest sample from which Radiolaria were recovered on Leg 20 . It is distinguished by its relatively heavy shell and three delicate spines.

Triactoma tithonianum is reported from the Tithonian of Yugoslavia and the post-Lias of Germany.

\section{Subfamily SATURNALINAE Deflandre, 1953}

Remarks: The generic assignment of saturnalins as for other actinommids has traditionally been based on the shape, number, and character of the shells. However, Mesozoic saturnalins are generally preserved without their shells, and it is thus not possible to adhere completely to this form of classification. Generic assignments have thus been made as explained under the "Remarks" for each genus.

\section{ACANTHOCIRCUS Squinabol, 1903}

Acanthocircus Squinabol, 1903, p. 124. Type species (subsequent designation by Campbell, 1954, p. D106) Acanthocircus irregularis Squinabol, 1903.

Remarks: Assigned to this genus are all Mesozoic saturnalins with a distinctly elliptical ring, with the spines of the ring concentrated at the ends of the ellipse. The largest dimension of the ring is in the plane perpendicular to that of the polar spines.

\section{Acanthocircus carinatus Foreman, new species} (Plate 5, Figures 1 and 2)

Description: The size and shape of the shell are not known because all specimens observed are broken and the shell is missing. The internal extension of the polar spine is smooth and suggests a porous rather than a spongy shell. No complete ring has been observed. Fragments indicate that it is elliptical with the ends of the ellipse not as broadly rounded as in $A$. trizonalis (?) and $A$. dizonius (?). It has one blade on the outer margin and two on the inner margin and bears two obliquely outward-directed spines, presumably one set at each end of the ellipse. Two distinct ridges or keels are developed on each side of the ring between the two spines, approximately parallel to the two end spines and perpendicular to the plane of the ring. Each ridge is offset from the other and each appears to be developed as an extension of one of the inner blades.

Measurements (based on 10 specimens, mostly fragmentary, from 196-4-1, piece 3 and 196-3-1, pieces 3, 2, and 1). Width of one-half of the ring from polar spines to outer margin, $185-225 \mu$; estimated greatest width of ring of five specimens, $370-450 \mu$; distance between outer margins of end spines near their base, $55-114 \mu$.

Remarks: Only the distinctive ends of the ellipse with their two spines and separating ridge or keel are preserved. However, since this fragment is so distinctive and easily recognized and is apparently useful for stratigraphic determinations, the species has been named and described here.

Early forms have a greater width between the end spines than late forms: $196-4-1(90-114 \mu) ; 196-3-1(65-98 \mu)$.

One specimen with a complete ring (Plate 5, Figure 3 ) had one end with a ridge between the spines as in this species, and the other end without a ridge as in $A$. sp. aff. Saturnalis variabilis, suggesting that the forms are closely related and that this specimen is a transitional form between the two species.

The ends of the ellipse of $A$. carinatus resemble those of $A$. sp. aff. Saturnalis variabilis but differ in having a distinctive ridge between the end spines.

Etymology: Latin carinatus, $-a,-u m$ keeled.

\section{Acanthocircus dizonius (Rüst) (?) (Plate 4, Figures 4 and 5)}

[?] Saturnulus dizonius Rüst, 1898, p. 8, pl. 2, fig. 3 . cf. Saturnalis dicranacanthos Squinabol, 1914, p. 289, pl. 22, figs. 4, 5,6 . Saturnulus sp. Fischli, 1916, p. 46, 47, fig. 55 .

Spongosaturnalis dicranacanthos (Squinabol) in Pessagno, 1969, p. 610 , pl. 4 , figs. A, B.

Description: As for Acanthocircus trizonalis (?) with the exception that the spine which extends from the saddle, instead of being simple as in $A$. trizonalis (?), is bifurcated. Rare specimens in the oldest sample (196-5, CC) tend to have the elliptical ring pointed rather than blunt.

Measurements (based on 10 specimens from 195B-2, CC, 196-3-1, piece 3, and 196-4-1, piece 3). Estimated width of shell, $100-125 \mu$, width of ring (to outer margin) at polar spines, $185-250 \mu$ (majority $185-230 \mu$ ), width of ring (to outer margin) in equatorial plane of shell, $345-590 \mu$ (majority $345-420 \mu$ ); length of end spines (from inner margin of ring), 90-125 .

Remarks: Because of the similarity of their rings it seems likely that the form described above and Acanthocircus trizonalis (?) are closely related. (See also remarks under $A$. trizonalis [?] .) However, no complete shells are preserved for either of these two species in the material studied. The form illustrated by Pessagno as Spongosaturnalis dicranacanthos (Squinabol), almost certainly conspecific with the form described above, has a poorly preserved spongy elliptical shell which may be comparable to the finely porous elliptical shell described by Rüst for Saturnulus dizonius. The latter apparently has the end spines broken off with only the basal saddle remaining. These two forms (Pessagno's and Rüst's) have a shell which differs markedly from Saturnalis dicranacanthos Squinabol which has a single spherical lattice shell with relatively large uniform pores. Because the form described here is considered conspecific with the form illustrated by Pessagno and because the shell of the latter is apparently similar to Saturnulus dizonius Rust, this species is assigned to the latter form rather than to Saturnalis 
dicranacanthos Squinabol with its markedly different shell. The assignment is doubtful because there is some question as to the form of the missing end spines of $S$. dizonius.

Saturnulus dizonius Rust is reported from the Upper Jurassic of Cittiglio and the Neocomian of Gardenazza, both in northern Italy, Saturnulus sp. Fischli from the probable Cretaceous of the Rigi in Switzerland, and Spongosaturnalis dicranacanthos (Squinabol) from the Tithonian or Berriasian of the Blake Bahama Basin.

\section{Acanthocircus trizonalis (Rust) (?)}

(Plate 4, Figures 6-8)

[?] Saturnulus trizonalis Rust, 1898 , p. 9 , pl. 2 , fig. 4 .

Saturnulus trizonalis Rust in Fischli, 1916, p. 46, 47, fig. 52.

Description: The size and shape of the shell is not known because all the specimens observed are broken and lack a complete shell. However, short thorns on the internal polar spines and fragments of spongy material adhering to some specimens suggest that the shell may have been spongy or had a more complicated structure as described by Rust. The distinctive elliptical ring, together with the polar spines, is frequently well preserved. The ring has its largest dimension in what would be the equatorial plane of the missing shell, and it is slightly constricted at the point where the smooth polar spines join the ring. The ends of the ellipse are generally rather blunt or broadly rounded, though rare specimens, particularly in the oldest sample (196-5, CC), tend to have the ends of the ellipse more pointed. Both halves of the ring may be approximately equal in size or, as is more frequently the case, one-half may be somewhat larger. The ring is three-bladed with one blade on the inner margin of the ring and two on the outer margin. This feature (two blades on the outer margin) has previously been described as a ridge on the outer margin. A distinctive abrupt widening of the two outer margin blades at the opposite ends of the ring forms a kind of saddle from which arise two lamellar subtriangular plates, one on each side of the ring. Each plate is apparently associated with a blade approaching the saddle from the opposite direction and is more developed on that edge. Thus, when these plates join at the apex of the triangles, they tend to form a slightly twisted offset arch from which a single lamellar spine, very variable in form, extends.

Measurements (based on 15 specimens from 196-4-1, piece 3, 196-3-1, piece 3 and 195-5, CB). Estimated width of shell, $110-150 \mu$; width of ring (to outer margin) at polar spines, 210-240 $\mu$; width of ring (to outer margin) in equatorial plane of shell, $335-550 \mu$; length of saddle and lamellar spines (from inner margin of ring), $75-130 \mu$.

Remarks: There is great variation in the development of the saddle, from very robust to almost vestigial. However, forms such as Saturnalis (?) aff. amissus Zhamoida (1969, pl. 1, fig. 9), which shows no saddle at all, are excluded. One specimen (Plate 16, Figure 23) with one spine simple and the other bifurcate as in $A$. dizonius (?) suggests that it is a transitional form and that the two species are closely related. From the samples at hand, it cannot be determined which of these two species was the ancestor.

The species is only doubtfully assigned to $S$. trizonalis Rust because of the question regarding the shell and because no evidence exists for the presence of half of a second elliptical ring in the plane of the polar spines perpendicular to the first ring, as described by Rust.

$S$. trizonalis is reported from the Upper Jurassic of Cittiglio and the Neocomian of Gardenazza, both in northern Italy, and the probable Cretaceous of the Rigi in Switzerland.

\section{Acanthocircus sp. aff. Saturnalis variabilis Squinabol}

(Plate 5, Figures 4 and 5)

Saturnalis variabilis Squinabol, 1914, p. 219, pl. 22, fig. 8 .

Remarks: Only fragments of the delicate elliptical ring of this species have been recovered. They show two simple, obliquely outward-directed end spines, and it is assumed that both ends of the elliptical ring have similar spines. The ring is three-bladed with one blade on the outer margin and two blades on the inner margin. Only one specimen of the variation with three spines (Plate 16, Figure 18) as described by Squinabol has been observed.

$S$. variabilis is reported from the Upper Jurassic of Cittiglio in northern Italy.
A similar form, Spongosaturnalis ? suboblongus Yao, 1972, from the Mesozoic of central Japan, differs in having a sturdier, three-bladed ring with two blades on the outer margin.

\section{SPONGOSATURNALIS Campbell and Clark, 1944}

Spongosaturnalis Campbell and Clark, 1944, p. 7. Type species (by original designation) Spongosaturnalis spiniferus Campbell and Clark, 1944.

Remarks: Assigned to this genus are all Mesozoic saturnalins with a spongy shell and a spiny ring which is approximately circular. The greatest dimension of each half ring is in the plane of the polar spines.

The species described below and other unnamed forms, which are only illustrated here, are doubtfully assigned to this genus because the nature of their shells is not known.

\section{Spongosaturnalis (?) aculeatus (Rust) (?) (Plate 4, Figure 2)}

[?] Zygostephanus aculeatus Rust, 1898, p. 37, pl. 7, fig. 13; Fischli, 1916, p. 46, 47, fig. 50, 51. (Not Zygostephanus aculeatus Rust? in Holmes, 1900 , p. 703, pl. 38, fig. 13.)

Description: The shell is missing but broken rings resemble that of $Z$. aculeatus Rust except that as in Acanthocircus trizonalis (?) there is no evidence for the presence of a half of a second elliptical ring in the plane of the polar spines perpendicular to the main ring. The ring is three-bladed with two blades on the inner margin. Spines are relatively short and lamellar, evenly distributed, and five on each half ring.

Measurements (based on three specimens from 194-4-1, piece 3). Estimated width of shell, $70-90 \mu$, width of ring (to outer margin) at polar spines, $200-225 \mu$, width of ring (to outer margin) in equatorial plane of shell, $140-150 \mu$.

Remarks: Z. aculeatus is reported from the Upper Jurassic of Cittiglio, northern Italy, and the probable Cretaceous of the Rigi in Switzerland.

Many superficially similar forms with only slight variations in the ring and number of spines are present through the middle Late Cretaceous. The shells are always missing. Some variations from different levels are illustrated: on Plate 4, Spongosaturnalis (?) $\mathrm{sp}$. aff. S. (?) aculeatus (Rüst); on Plate 14, Spongosaturnalis (?) sp. cf. $S$. (?) aculeatus (Rust); and on Plate 15, Spongosaturnalis (?) sp. Until something is known about their shells, these simple, relatively large, circular, spiny rings do not appear to be useful for stratigraphic work.

\section{Spongosaturnalis (?) multidentatus (Squinabol)} (Plate 15, Figure 4)

Saturnalis multidentatus Squinabol, 1914, p. 298, pl. 23, figs. 11, 12.

Remarks: $S$. multidentatus is reported from the Middle Cretaceous of Novale, northern Italy.

\section{Spongosaturnalis (?) sp. cf. Zygostephanus aculeatus (?) Ruist in Holmes, 1900}

(Plate 14, Figure 10)

cf. Zygostephanus aculeatus (?) Rust in Holmes, 1900, p. 703, pl. 38 , fig. 13.

Remarks: The form present here resembles the species illustrated by Holmes in that the ring has spines with blunt tips and at least one of the sets of spines bracketing a polar spine has the spines parallel.

Z. aculeatus (?) in Holmes is reported from the Holaster planus Zone of the Upper Chalk (Late Turonian) from Coulsdon, Surrey, England.

\section{Family HAGIASTRIDAE Riedel, emend. Pessagno, 1971}

Remarks: Except for one species, Paronaella (?) diamphidia, the Hagiastridae are not treated in detail here. Three-armed spongy forms from the Early Cretaceous samples are illustrated on Plates 5 through 8 to indicate the variety of forms present. 


\section{Subfamily PATULIBRACCHIINAE Pessagno, 1971}

\section{Genus PARONAELLA Pessagno, 1971}

Paronaella Pessagno, 1971, p. 46. Type species (by original designation) Paronaella solanoensis Pessagno, 1971.

Remarks: The species below are only doubtfully assigned to Paronaella because they all apparently lack a brachiopyle and because, as in the case of $P$. (?) diamphidia, the arms are unequal.

\section{Paronaella (?) diamphidia Foreman, new species} (Plate 8, Figures 3 and 4)

Description: The shell is basically a three-armed hagiastrid with longitudinal structure, if any, completely masked by an irregular spongy meshwork (patagium?). This is developed more particularly on two of the arms to form an approximate horseshoe shape, with the less-developed third arm extending obliquely from the apex of the horseshoe. On well-preserved specimens, short, irregularly arranged, lamellar spines are present near the ends of the three arms.

Measurements (based on 10 specimens from 196-5, CC, 196-4-1, piece 3 and 196-3-1, piece 2). Greatest distance between outer margins of two most prominent arms, $170-280 \mu$; between inner margin near end of two most prominent arms, 70-150

Remarks: This very distinctive form differs from other species of Paronaella in the development of an irregular spongy meshwork on two of its arms. Forms with the third arm equal, except for the absence of the patagium and extending vertically rather than obliquely, are not included (Plate 8, Figure 5).

Etymology: Greek diamphidios, $-e$, - on $=$ diamphidius, $-a,-u m$ utterly different.

\section{Paronaella (?) ewingi Pessagno (?)}

(Plate 8, Figure 1)

[?] ? Paronaella ewingi Pessagno 1971, p. 47, pl. 19, figs. 2-5,

Remarks: The species illustrated from the Sethocapsa trachyostraca assemblage is only doubtfully assigned to ? P. ewingi because the number of spines on the ray tips is uncertain.

? $P$. ewingi is reported from the Tithonian or BerriasianValanginian of the Blake-Bahama Basin, DSDP Leg 1.

\section{Paronaella (?) sp.}

(Plate 8, Figure 2)

Remarks: This form from the Sethocapsa cetia assemblage differs from ? Paronaella ewingi Pessagno and P. (?) ewingi (?) illustrated here in having a markedly larger central area and flattened ray tips.

\section{Family PSEUDOAULOPHACIDAE Riedel, 1967}

ALIEVIUM Pessagno, emend. Foreman

Alievium Pessagno, 1972, p. 297. Type species (original designation by Pessagno, 1972, p. 297) Theodiscus superbum Squinabol, 1914.

Remarks: Alievium is here emended to include circular as well as triangular forms.

\section{Alievium sp. cf. A. praegallowayi Pessagno}

(Plate 14, Figures 12 and 15)

cf. Alievium praegallowayi Pessagno, 1972, p. 301, pl. 25, figs. 2, 3.

Remarks: The forms illustrated here lack the definite pseudoaulophacid pattern of the species to which they are compared. They do have the same type of spine which is three-bladed proximally and circular to triangular in cross-section distally.

A. praegallowayi is reported from the late Turonian-early Coniacian to early Santonian of California.

\section{Alievium sp.}

(Plate 9, Figures 1 and 2)

Description: The shell is circular to subtriangular (convex sides) in transverse section, elliptical in vertical section, greatest height about one-half the width of the shell. It bears three slender, rather delicate, three-bladed spines equally spaced on its margin when the shell is circular and arising from the points of the triangle when subtriangular. Its surface is covered with the triangular pore pattern with nodes at the junction of the intervening bars which is characteristic of all the pseudoaulophacidae. There are from six to eight nodes across the width of the shell, and when well developed, short cylindrical spines extend from the apex of each node.

Measurements (based on 25 specimens from 196-4-1, piece 3 and 196-3-1, pieces 3,2 and 1). Greatest width of shell, 85-150 $\mu$; width of spines near base, $20-27 \mu$; length of spines, $95-215 \mu$.

Remarks: There is considerable variation in the size and shape of this form. The large forms $(130-150 \mu)$ are almost always circular; however, among the smaller forms $(85-125 \mu)$, both circular and subtriangular forms are common, with triangular forms predominating among the very small forms $(85-110 \mu)$. At this time no species distinction is made on the basis of this variability. Excluded are small forms which have straight, not convex sides, and are perfectly triangular.

This species differs from the species of Alievium described by Pessagno, 1972 in its having fewer nodes, a generally smaller size, and a more variable shape.

The presence of this pseudoaulophacid in sediments of Valanginian-early Hauterivian age extends the range of this genus from the previously earliest known form in the late Aptian of the Blake-Bahama Basin.

\section{EMILUVIA Foreman, new genus}

Type species: Emiluvia chica Foreman, n.sp.

Definition: The shell is a rectangle, or a modified rectangle, with four spines, one at each corner arranged to form a cross. Surface with nodes arranged in a pseudoaulophacid pattern over-all or only partially.

Remarks: This genus differs from Alievium in having a shell of rectangular shape with four spines arranged to form a cross.

The presence of the two species of Emiluvia described here in sediments of Neocomian-?Late Jurassic age extend the range of the family Pseudoaulophacidae from the previously earliest known form in the late Aptian of the Blake-Bahama Basin.

Etymology: Emiluvia $\mathrm{f}$. is an anagram of the closely related genus Alievium.

\section{Emiluvia chica Foreman, new species} (Plate 8, Figure 7)

Description: The shell is small, rectangular with concave sides in transverse section, elliptical in vertical section. It bears a three-bladed spine at each corner. No more than two complete spines were observed on a specimen. These varied somewhat in length on individual specimens. The surface is covered with large nodes, of which two at the base of each spine on both faces of the rectangle are especially large. The remaining nodes, not quite so large, are arranged in rows with connecting bars to form rectangles or less regularly with connecting bars to form triangles as in the Pseudoaulophacidae.

Measurements (based on 10 specimens from 196-5, CC). Width of shell from point midway between spines to opposite side, $100-140 \mu$ (majority 110-125 $\mu$ ); approximate number of nodes across shell from one spine to the opposite spine is five to six.

Remarks: This species differs from the similar $E$. pessagnoi as described under that species.

Etymology: Spanish chico, $-a=$ chicus, $-a,-u m$ small.

\section{Emiluvia pessagnoi Foreman, new species} (Plate 8, Figure 6)

Description: The shell is large, rectangular with concave sides in transverse section, elliptical in vertical section. It bears a three-bladed spine at each corner of the rectangle, the four spines oriented as in a cross. All the specimens observed had their spines broken so it is not known whether they are equal in length. The surface is covered with nodes which extend in two approximately parallel rows from each spine toward the center where they are less regularly arranged. Parallel bars connect the nodes near the spines to form small rectangles with a node at each corner. Centrally, the connecting bars tend to form triangles as in the pseudoaulophacidae. Nodes near the bases of the spines tend to be larger than those near the center of the shell. 
Measurements (based on 10 specimens from 196-5, CC). Width of shell from point midway between spines to opposite side, $155-215 \mu$ (majority $185-215 \mu$ ); approximate number of nodes from one spine to the opposite spine, 10-14.

Remarks: This species is distinguished from Emiluvia chica by its larger size and more numerous, less prominent nodes.

This species is named for Emile Pessagno, Jr. in recognition of his work with the Pseudoaulophacidae of California.

\section{Suborder NASSELLARIA Ehrenberg, 1875 \\ Family AMPHIPYNDACIDAE Riedel, 1967 \\ Genus AMPHIPYNDAX Foreman, 1966}

Amphipyndax Foreman, 1966, p. 355. Type species (by original designation) A mphipyndax enesseffi Foreman, 1966.

\section{Amphipyndax (?) spp.}

(Plate 9, Figures 3-5)

cf. Lithocampe fasciata Rüst, 1885 , p. 63 , pl. 18, fig. 3 .

cf. Stichocapsa fasciata Rust, 1885, p. 65 , pl. 18, fig. 6 .

cf. Dictyomitra nassa Parona, 1890, p. 170, pl. 6, fig. 10.

Remarks: Some rare distinctive spindle-shaped forms are present in samples 196-5, CC to 196-3-1, piece 1 and in 195-5, CB which may be compared to the forms listed in the synonymy. At least two separate types are identified, one with nodes forming a distinct ridge only at the segmental division (Plate 9, Figures 3,4) and the other with nodes distributed irregularly (Plate 9, Figure 5). This latter form is extremely rare. Besides their shape and the surface ornamentation of nodes they have in common a large, poreless, rounded cephalis, externally very like the cephalis of members of the family Amphipyndacidae. However, the internal structure of the shell has never been clearly seen and these forms are thus only questionably assigned to the genus Amphipyndax.

Lithocampe fasciata, Stichocapsa fasciata, and Dictyomitra nassa are reported from the Upper Jurassic of Cittiglio, northern Italy.

\section{Genus DICTYOMITRA Zittel, 1876}

Dictyomitra Zittel, 1876, p. 77. Type species (subsequent designation by Campbell, 1954, p. D140) Dictyomitra multicostata Zittel, 1876.

Remarks: Assigned to this genus are all forms in the Mesozoic material with conical shape and five or more segments. The aperture may be wide open or very slightly constricted. This is a very broad interpretation of the genus and thus numerous phylogenetic lineages are no doubt represented. One species only tentatively included, $D$. (?) lacrimula, has a more constricted aperture.

\section{Dictyomitra alievi Foreman, new species}

(Plate 9, Figure 10; Plate 16, Figure 4)

Description: The shell is conical, of 10 to at least 15 segments. The cephalis and thorax have no, or only a few pores, and the cephalis bears a small slender horn, generally only a little stub. The first two to three segments are conical, smooth, with no external segmental divisions. The remaining segments are clearly defined by a row of small nodes along each division. Slender ridges extend between these nodes and onto the adjacent segments, sometimes forming a pattern of triangles. Pores are rounded, closely spaced, arranged in transverse rows generally three, rarely four, to a segment. After the first three segments, the remaining ones are uniform, increasing in length and width only very gradually. The distal margin is ragged.

Measurements (based on 10 specimens from 196-4-1, piece 3, 196-3-1, pieces 3 and 1, and 194-5, CC). Length of longest specimen of 15 segments, $335 \mu$; of first 10 segments, $210-230 \mu$; greatest width, $120-175 \mu$.

Remarks: This species is distinguished from $D$. cosmoconica by its smaller size, smaller, less regularly arranged pores, and segmental division which externally consists of individual more widely separated nodes.

It is named for Dr. K. S. Aliev in recognition of his work with Early Cretaceous Radiolaria.
Dictyomitra carpatica Lozyniak (?)

(Plate 10, Figures 1-3; Plate 16, Figure 5)

[?] Dictyomitra carpatica Lozyniak, 1969, p. 38, pl. 2, figs. 11, 12, 13.

Description: The shell is conical except for the last segment which is narrower than the next adjacent one and tends to be cylindrical in shape. There are 9 to 13 segments, generally 11 to 12 . The first four or five segments form a smooth tapering cone with no external segmental division; rarely, a single transverse row of pores can be seen at each division; the remaining segments, except the last as mentioned above, can easily be distinguished by the characteristic thickening of the distal half of each segment. When this is well developed it gives the appearance of a rectangular ridge. A single row of transverse pores, generally closely spaced, is present at each segmental division immediately below the expanded "ridge". Vertical costae extend from the approximate center margin of some of the pores to join the center margin of the next row of pores. These costae are irregularly spaced with generally two or three, rarely four, pores between each adjacent costa. Because these costae generally do not extend vertically between the pores, they are discontinuous on each segment.

Measurements (based on 13 specimens from 196-5, CC, 196-4-1, piece $3,196-3-1$, pieces 3 and 2 , and 195-5, CB). Total length of one specimen of 9 segments, $155 \mu$; of longest broken specimen of 13 segments, $350 \mu$; of the majority of specimens which have 11 to 12 segments, $230-265 \mu$; length of first 8 segments, $125-185 \mu$; greatest width at next to last segment, $85-155 \mu$.

Remarks: The specimens studied here agree in general with the description and illustration of Lozyniak for $D$. carpatica. They are questionably assigned to this species only because of uncertainty regarding the arrangement of pores and costae.

D. carpatica is reported from the Neocomian of the Ukranian Carpathians, USSR.

\section{Dictyomitra cosmoconica Foreman, new species}

(Plate 9, Figure 11; Plate 16, Figure 3)

Description: The shell is conical proximally, tending to be cylindrical distally, and consists of 10 to 13 uniform segments which increase only very gradually in length distally. The cephalis and thorax have no, or only a very few pores. Rarely, the cephalis bears a narrow, short, blunt horn. After the first two segmental divisions, which are externally smooth, the segmental divisions are distinguished by a raised ridge formed by the thickening of the intervening pore bars at this point. Pores are rounded, arranged quincuncially in two to three transverse rows. The pores also show a distinct diagonal alignment. Pores on adjacent segments are not opposed and, thus, the diagonally aligned rows tend to be continuous between adjacent segments. The intervening pore bars between these diagonal rows may be slightly raised and, indeed, they form vertical to diagonal ridges or nodes of varying prominence on the transverse segmental dividing ridge as they cross from one segment to another. The terminal margin on all of the specimens observed is ragged and apparently broken.

Measurements (based on 10 specimens from 196-5, CC). Length of longest specimen of 13 segments, $450 \mu$; of first 10 segments, $310-380 \mu$; greatest width $160-217 \mu$.

Remarks: This species is distinguished from Dictyomitra alievi as described under that species.

Etymology: Greek kosmos n. adornment + konos n. cone + $-i k o s,-e,-o n$ related to $=$ cosmoconicus, $-a,-u m$ like an ornate cone.

\section{Dictyomitra (?) lacrimula Foreman, new species} (Plate 10, Figure 11)

Description: The shell is spindle-shaped, of six or seven segments. These increase gradually in length and width until the last one or two segments which constrict, terminating in a narrow aperture with a smooth margin. Externally, the segmental divisions can sometimes be distinguished by very slight identations of the shell wall. Longitudinal ribs, approximately 10 per half a circumference, extend from the thorax to the aperture. A single vertical row of pores is present between adjacent ribs; these may be rounded or elliptical with the long axis transverse. 
Measurements (based on 10 specimens from 195-5, CB and 194-5, CC). Length of shell, 205-255 $\mu$; greatest width of shell, $85-130 \mu$.

Remarks: This species differs from Cyrtocalpis duodecimradiata Rust, 1898 in having more segments and a much narrower aperture with a smooth margin.

Etymology: Latin lacrimula f. dim. little tear.

\section{Dictyomitra leptoconica Foreman, new species} (Plate 10, Figure 4; Plate 16, Figure 6)

cf. Dictyomitra turritella Parona, 1890 , p. 170, pl. 6, fig. 5 .

Description: The shell is conical except for the last segment which is narrower than the next adjacent segment and tends to be cylindrical in shape. There may be 9 to 14 segments, generally 10 to 12. The first four or five segments form a smooth cone with no external segmental division. The remaining segments, except the last, are distinguished by being expanded near their lower margin. A row of small closely spaced pores is present at the segmental division. Slightly irregular, vertical costae extend from the center margin of some of the pores to join the center margin of the next row of pores. These costae are closely spaced, a single costa arising from the margin of each pore on the median and distal segments, and are more widely spaced proximally. Because they do not extend vertically between the pores they are discontinuous on each segment.

Measurements (based on 15 specimens from 196-4-1, piece 3, and 196-3-1, pieces 3,2, and 1). Total length of 2 specimens of 10 segments, $175 \mu$ and $185 \mu$; of longest broken specimen of 13 segments, $340 \mu$; of the majority of specimens which have 11 to 12 segments, $205-230 \mu$; length of first 8 segments, $110-185 \mu$ (majority 110-140 $\mu$ ); greatest width, $95-150 \mu$.

Remarks: This species is distinguished from $D$. carpatica by lacking the rectangular appearing ridge and by its more closely spaced costae. Not included at this time is a related younger form with more widely spaced costae (Plate 16, Figure 7). D. leptoconica may be compared with $D$. turritella Parona. However, the larger size and lack of costae of $D$. turritella do not allow certain identification at this time. D. turritella is reported from the Upper Jurassic of Cittiglio, northern Italy.

\section{Dictyomitra somphedia Foreman, new species} (Plate 14, Figure 18)

Description: The shell is large, elongate, with an indeterminate number of segments. The cephalis is poreless and may be entirely hidden in the wall of the shell or protrude slightly. Generally, the apex is smooth; rarely, a small short horn is present. In one specimen only, a short thoracic segment equaling the cephalis in length was observed. Other segmental divisions, if any, are obscured by the thick wall of the shell. The proximal one-third to one-half of the shell is smooth, thick walled, with large pores varying considerably in size and shape. The remainder of the shell is rough with a thick spongy wall with a thin overlay of pores in the same size and pattern as in the proximal part of the shell. They differ only in their thickness. There is generally a distinct broadening of the shell at the point where the wall structure changes. The distal margin is ragged and apparently open.

Measurements (based on 10 specimens from 195-3, CC). Length of shell, $325-420 \mu$; greatest width of shell, $170-250 \mu$ (majority $170-215 \mu)$.

Remarks: This species is distinguished by its large size, shape, and combination of large pores and spongy structure.

Etymology: Greek somphos spongy + hedos $\mathrm{m}$. base $+-i o s,-a$, - on related to $=$ somphedius, $-a,-u m$ with a spongy base.

\section{Dictyomitra veneta (Squinabol)}

(Plate 14, Figure 11)

Dictyomitra veneta (Squinabol) in Petrushevskaya and Koslova, 1972 , p. 550, pl. 2, fig. 2. (Not Phormocyrtis veneta Squinabol, 1903 , p. 148 , pl. 9 , fig. 30 .)

Remarks: Dictyomitra veneta is reported from sediments of Cenomanian age from DSDP Leg $14,137-7$, CC.
Dictyomitra sp. cf. D. spicularia Aliev

(Plate 9, Figures 8 and 9)

cf. Dictyomitra spicularia Aliev, 1961, p. 34, pl. 2, figs. 1, 2; 1965 , p. 39 , pl. 6 , fig. 9 .

Remarks: This form with its alternating rows of small and large nodes differs from $D$. spicularia in having the rows more widely spaced. It may be an ancestor of the form described by Aliev.

D. spicularia is reported from the late Albian-Cenomanian of Azerbaidzhan.

\section{Dictyomitra (?) sp. aff. Lithostrobus rostovzevi Lipman (Plate 14, Figure 19)}

aff. Lithostrobus rostovzevi Lipman, 1960, p. 133, pl. 32, figs. 1-10

Remarks: The form illustrated here appears to be closely related to Lithostrobus rostovzevi from the Campanian-Santonian of the western Siberian lowland. It differs only in having a slight thickening at the segmental strictures rather than andentation as for $L$. rostovzevi.

\section{Dictyomitra sp.}

(Plate 14, Figure 16)

Remarks: Only one specimen of this species was found in the material (195-3, CC) studied. It is briefly treated here because similar forms (i.e., with the proximal segments broadly conical) are known from the Albian-Cenomanian of Azerbaidzhan (Aliev, 1965), from the Cenomanian of Romania (reference material from Paulian Dumitrica), and from the Cenomanian of DSDP, Leg 14, 137-7, CC. A few species with this feature are described by Squinabol (1903, 1904) from the Late Cretaceous of northern Italy.

\section{Genus EUCYRTIS Haeckel, 1881}

Eucyrtis Haeckel, 1881, p. 438. Type species (here designated) Eucyrtis conoidea Rüst, 1885.

Remarks: It is not likely that the species described below is closely related to the type species of this genus. However, there is some similarity in that they are both multisegmented, slender, constricted distally, and bear a horn, and it is on that basis that it is tentatively assigned to this genus.

Eucyrtis (?) zhamoidai Foreman, new species

(Plate 10, Figures 9 and 10; Plate 16, Figures 1 and 2)

Eusyringium sp. A in Zhamoida et al., 1968, pl. 1, fig. 8; Zhamoida, 1969 , p. 19, fig. 8.

Description: The shell is multisegmented, slender, long, and constricted to terminate in a slender, long, closed (?) tube. The cephalis bears a small short horn and is poreless or with only a few pores. The remaining segments except for the terminal tube increase only gradually in length distally. They increase in width to a point which varies from approximately one-third to one-half the length of the shell after which they gradually decrease in width until the terminal tube becomes more or less cylindrical. There is very little external segmental division. However, in some specimens the surface is roughened by tiny spines which tend to concentrate at the segmental divisions and thus help to define these divisions. The distal margin of the tube appears ragged and broken and, in only one specimen, was observed to close and end with a short spine. Pores are small, fairly uniform in size on individual specimens though varying somewhat in size among individuals. They are closely spaced, arranged irregularly with only a slight tendency toward transverse alignment.

Measurements (based on 20 specimens from 196-4-1, piece 3, 196-3-1, pieces 3, 2, and 1, 195-5, CB, 194-5, CC, and 194-4, CC). Length of one unbroken specimen, $270 \mu$, of longest broken specimen, $350 \mu$; greatest width, $45-100 \mu$ (majority $55=80 \mu$ ).

Remarks: This species is named for Professor A. I. Zhamoida who illustrated this form in his work with Mesozoic Radiolaria of Sakhalin. He reports finding it in a radiolarian complex with saturnalins in strata considered to be Late Mesozoic in age. 
Genus STICHOCAPSA Haeckel, 1881

Stichocapsa Haeckel, 1881, p. 439. Type species (subsequent designation by Campbell, 1954, p. D143) Stichocapsa jaspidea Rust, 1885.

Remarks: It is not likely that the species described below is closely related to Stichocapsa jaspidea, the type species of Stichocapsa. The generic assignment remains unchanged merely as a convenience until a more suitable assignment can be made.

Stichocapsa (?) rotunda Hinde

(Plate 11, Figures 1 and 2; Plate 16, Figure 20)

Stichocapsa rotunda Hinde, 1900 , p. 41, pl. 3, fig. 24. cf. Stichocapsa conglobata Rüst, 1885, p. 319, pl. 32, fig. 5. cf. Stichocapsa verbana Parona, 1890, p. 171, pl. 6, fig. 14.

Description: The shell is large and conical, very variable in size, of approximately five to eight segments. Preservation and the thick shell wall make observation difficult. Proximally, the first three or four segments, generally without visible external strictures, are conical and smooth, except basally where the conical section may be roughened. The remaining segments are well defined externally, generally inflated, sometimes flattened apically, rapidly increasing in size. Their surface is rough, irregularly spongy, sometimes with an overlay of large rounded pores, irregular in size. No aperture is apparent.

Measurements (based on 12 specimens from 196-5, CC, 196-4-1, piece 3, and 196-3-1, piece 1). Maximum width of shell, 200-370 $\mu$; length, $311-650 \mu$.

Remarks: This species agrees very well with Hinde's description of $S$. rotunda except for his uncertainty as to the surface pore structure ("Only faint indications of pores are shown."). It differs more from $S$. conglobata Rust and $S$. verbana Parona in its form and in having a spongy surface, lacking the small regular pores of those two species.

$S$. rotunda Hinde is reported from the probable Jurassic or possible Lower Cretaceous of Central Borneo; $S$. conglobata from the Jurassic (post-Lias) of Urschlau, Germany; and S. verbana from the Upper Jurassic of Cittiglio, Italy.

\section{Genus TRIPILIDIUM Haeckel, 1881}

Tripilidium Haeckel, 1881, p. 428. Type species (subsequent designation by Campbell, 1954, p. D117) Tripilidium nanum Rust, 1885 .

Remarks: Most of the species which have previously been assigned to Tripilidium and those illustrated here are probably not closely related to its type species, $T$. nanum. The illustrated species, briefly described below, are questionably assigned to this genus as a matter of convenience pending further study.

Tripilidium (?) sp. A

(Plate 10, Figures 13-15)

Description: The two-segmented shell has a poreless cephalis which bears a long, sturdy, three-bladed, apical horn and a short, stubby, vertical horn. The thorax is short and somewhat inflated. The three feet are three-bladed and straight.

$T$. (?) sp. A may be conspecific with Tripilidium bononiense Neviani, 1900 from the Upper Jurassic of Grizzana, northern Italy, or $T$. obliquum Hinde (1900) from probably Jurassic or possibly Lower Cretaceous jasper of central Borneo.

Tripilidium (?) sp. B

(Plate 10, Figures 16-18)

Description: The two-segmented shell has a poreless cephalis which bears a short horn. The thorax is hemispherical, longer, more slender than for $T$. (?) sp. A, and the three feet are three-bladed and curved with convexity outward.

$T$. (?) sp. B may be conspecific with the two forms of Tripilidium debile Rust illustrated by Fischli in 1916 from the probable Lower Cretaceous of the Rigi, Switzerland.
Tripilidium (?) sp. C

(Plate 10, Figure 19)

Description: The two-segmented shell has a poreless cephalis and bears a long, sturdy, three-bladed apical horn. The thorax is pyramidal in shape, and the three feet are three-bladed and straight.

$T$. (?) sp. C differs from $T$. (?) sp. A in the pyramidal shape of its thorax.

\section{Subfamily SYRINGOCAPSINAE Foreman, new subfamily}

Type genus: Syringocapsa Neviani, 1900, p. 662.

Definition: Cyrtoidea with the multiple segments of the proximal part very small and the single segment of the distalmost part very large and expanded. A terminal tube may or may not be present. None of the proximal segments are hidden and the cryptocephalic and cryptothoracic nassellaria of Dumitrica (1970) are therefore excluded. Constituent genera are: Dibolachras n.g.; Podocapsa Rust, 1885; Podobursa Wisniowski, 1889, emend.; Sethocapsa Haeckel, 1881; Syringocapsa Neviani, 1900; Trisyringium Vinassa, 1901-1902; Urocyrtis Pantanelli, 1880

\section{DIBOLACHRAS Foreman, new genus}

Type species: Dibolachras tytthopora Foreman n. sp.

Definition: The shell is of three to four (?) segments, the small proximal part made up of all but the large distalmost segment which is expanded and bears only two spines and a porous terminal tube.

Remarks: This genus differs from Podobursa in having only two spines.

Etymology: Greek dibolos two-pointed + achras $\mathrm{f}$. wild pear $=$ dibolachras $\mathrm{f}$. two-pointed wild pear.

Dibolachras apletopora Foreman, new species

(Plate 11, Figure 3; Plate 16, Figures 10 and 11)

Description: The shell is of three (?) segments, a cephalis with a short, stubby, smooth or slightly ridged horn, a short thorax, and a large subglobose abdomen terminating in a closed tube. The first two (?) segments form a small conical proximal portion. Because preservation is poor, the possibility remains that there may be an additional segment here. The cephalis has few or no pores, and the one or two postcephalic segments have small irregular pores. The large abdomen with large rounded pores in angular pore frames is flattened proximally and bears two sturdy, basally bladed, terminally smooth spines which are directed outward horizontally or slightly upward and originate on the proximal half of the abdomen. A slender subcylindrical tube with pores as for the remainder of the abdomen, terminating in a smooth spine, depends distally.

Measurements (based on 10 specimens from 196-5, CC). Length overall (three specimens only), $365-448 \mu$; of small proximal part, 77-93 $\mu$; of abdomen, $112-145 \mu$; width of abdomen, $155-186 \mu$.

Remarks: This species differs from Dibolachras tytthopora and Podobursa tetracola as described under those species.

Etymology: Greek apletos large + poros n. pore = apletoporus, $-a,-$ um large pored.

\section{Dibolachras tytthopora Foreman, new species} (Plate 11, Figure 4; Plate 16, Figure 15)

Description: The shell is of three or four segments, pyriform with a slender, closed, terminal tube and two very sturdy, three-bladed, outward-directed spines. Preservation and the rather dense shell wall of small irregular pores make it impossible to distinguish individual segments. The narrow proximal part is apparently composed of a small cephalis bearing a moderate to fairly long, smooth or only slightly ridged, apical horn and one or two small postcephalic segments with small irregular pores, sometimes with a spongy overlay. The large subglobose abdomen has slightly larger pores, on some specimens very irregular and sometimes with a slightly spongy overlay or with surface slightly nodose. Its terminal tube has larger rounded pores and terminates in a smooth spine.

Measurements (based on 15 specimens from 196-4-1, piece 3, 196-3-1, pieces 2 and 1). Length overall (estimated), 295-450 ; 
length exclusive of tube, $185-260 \mu$ (majority $200-230 \mu$ ), of wings,

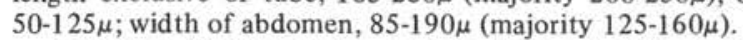

Remarks: Younger forms tend to be larger with a longer horn and longer spines, and the surface of the abdomen tends to be weakly nodose. This species differs from $D$. apletopora in the character of the pores, its pyriform shape, and the wings which are three-bladed throughout their length.

Etymology: Greek tytthos small + poros n. pore = tytthoporus, $-a,-u m$, small pored.

\section{Genus PODOBURSA Wiśniowski emend. Foreman}

Podobursa Wiśniowski, 1889 , p. 686. Type species (by monotypy) Podobursa dunikowskii Wiśniowski, 1889.

Remarks: Although Wiśniowski considered $P$. dunikowskii to be a monocyrtid with three lateral spines on the cephalis and a porous extension apically, it is apparent that the apical porous extension is actually the terminal tube of the distalmost segment and that the small proximal part of the shell, comprising the cephalis, thorax and perhaps a small postthoracic segment, is missing. The generic definition of Podobursa is thus emended as follows:

Shell of three to four segments, the small proximal part made up of all but the distalmost segment which is large, globose, and bears three or more outward-directed spines and a porous terminal tube.

This genus differs from Podocapsa Rust emend. Foreman in having appendages developed as three or more solid spines rather than as three porous cones or tubes.

Assigned to this genus are all Mesozoic forms with a small proximal part and a large, globose terminal segment with three or more solid spines (wings) and a terminal tube.

\section{Podobursa (?) polylophia Foreman, new species (Plate 11, Figures 8 and 9)}

Description: The shell is composed of three segments, a cephalis and thorax comprising a small conical proximal part and a large globose abdomen with a closed terminal tube. The cephalis bears a sturdy, smooth conical horn, varying considerably in length. No segmental division between the cephalis and thorax can be distinguished, and the pores are small and somewhat irregular. The large abdomen is wider than it is high, circular in transverse section and elliptical in vertical section. Pores are rounded, moderate and somewhat irregular in size, and the surface of the shell is nodose. It bears three to four spines which are smooth, circular to triangular in cross-section and equally disposed around the widest part of the shell. There is some evidence that rare specimens may have as many as five spines. The terminal tube tapers to close with a smooth conical spine. Its pores are equal to or slightly larger than those of the abdomen.

Measurements (based on 10 specimens from 196-5, CC, 196-4-1, piece 3 and 196-3-1, piece 3). Length overall, 295-490 $\mu$; of cephalis and thorax exclusive of horn, $35-65 \mu$; of abdomen exclusive of tube, $100-170 \mu$; greatest width of abdomen, $125-215 \mu$.

Remarks: This species is distinguished from Syringocapsa limatum by its generally smaller size, presence of abdominal spines, and smaller apical horn. It is questionably assigned to Podobursa because of the nodose nature of the shell. A single specimen of a broken younger form (195-5CB), not included in this species, had at least one sturdy three-bladed spine.

Etymology: Greek polys many + lophos n. crest of hill = polylophus, $-a,-u m$ with many hills.

\section{Podobursa tetracola Foreman, new species}

(Plate 13, Figure 10; Plate 16, Figure 14)

cf. Theosyringium larva Parona, 1890, p. 168, pl. 6, fig. 1 .

Description: The shell is of four segments, a cephalis, thorax, one small abdominal segment, and a large, globose abdominal segment terminating in a closed tube. The first three segments form a narrow, subcylindrical to conical neck with a short smooth horn at the apex. The cephalis is apparently poreless and the two postcephalic segments have small irregular pores. Sometimes it is not possible to distinguish these three segments individually. The large abdomen may be almost spherical or somewhat flattened. A slender subcylindrical tube, terminating in a smooth spine, depends distally. The abdomen bears three sturdy, outward-directed spines, which are three-bladed basally or throughout. Pores are large with subangular frames, fairly uniform in size and shape; those on the terminal tube are similar.

Measurements (based on 10 specimens from 196-5, CC). Length overall (four specimens only), $300-400 \mu$; of cephalis, thorax and abdomen, 160-225 ; of abdomen, 100-170 $\mu$; of tube (five specimens only), $100-230 \mu$; width of abdomen, $125-190 \mu$; of pores, 10-20 $\mu$.

Remarks: This species may be compared with Theosyringium larva Parona, 1890. However, that form is illustrated from a thin section and shows broken or deformed proximal segments with only two small spines on the abdomen.

This species differs from Dibolachras apletopora in having three sturdy spines. Theosyringium larva is reported from the Upper Jurassic of Cittiglio in northern Italy.

Etymology: Greek tetrakolos, -on = tetracolus, $-a,-$ um four membered.

\section{Podobursa triacantha (Fischli)}

(Plate 13, Figures 1-7)

Theosyringium acanthophorum Rust var. triacanthus Fischli, 1916, p. 47 , fig. 38 .

Theosyringium acanthophorum Rust var. tetracanthus Fischli, 1916, p. 47 , fig. 39 .

Theosyringium acanthophorum Rust var. polyacanthus Fischli, 1916, p. 47 , fig. 41.

[?] Staurostylus sp. Lozyniak, 1969, pl. 1, fig. 4.

[?] Stylostaurus sp. Lozyniak, 1969, pl. 1, fig. 6 .

Description: The shell is of four segments. The cephalis and two postcephalic segments form a small, slender, conical proximal part, and the large globose abdominal segment with terminal tube, the major distal portion. Preservation makes it difficult to distinguish the proximal segments individually, and it is possible that more segments may be present in the small proximal part. Apparently there is a small poreless cephalis with a smooth slender horn. The margin of the cephalis and the first postcephalic segment merge without any indentation. This second segment may have only a few small pores or, as in some specimens, more numerous, large, irregularly arranged pores. The two postcephalic segments may be distinguished from each other by the indentation of the margin between them, and by the greater width of the last one. It has small, uniform, circular pores. The abdomen, which comprises the major portion of the skeleton, has large uniform pores with subangular pore frames; on their lower inner margin they are scalloped, and sometimes a subdivision of the pore into numerous small pores may be seen. Sometimes the pores appear to be arranged in vertical rows, sometimes in transverse rows, and sometimes without rows. Pores of the tube are similar. Three to six outward-directed, slender, distally smooth spines arise from the abdomen medianly; basally they are expanded and bladed by the abdominal pore bars elongating to form a broad base for the spines, sometimes developing open arches.

Measurements (based on 10 specimens from 196-4-1, piece 3 and 196-3-1, piece 2). Length overall, $350-405 \mu$; of cephalis and two postcephalic segments, $65-85 \mu$; of abdomen, $110-170 \mu$; of tube $130-170 \mu$; width of abdomen, $125-200 \mu$; of pores, $12-20 \mu$.

Remarks: Fischli (1916) illustrated four varieties of Theosyringium acanthophorum Rust: $T$. acanthophorum triacanthus, T. acanthophorum tetracanthus, $T$. acanthophorum hexacanthus, and T. acanthophorum polyacanthus. No written descriptions are given and the illustrations are very small. The illustration for $T$. acanthophorum hexacanthus (p. 47, fig. 40) shows a spherical form with multiple spines and is not considered to belong to this group. The remaining three forms are all very similar except for the number of spines. This is exactly the same situation which prevails here, numerous similar forms with a variable number of spines. The forms illustrated by Fischli differ only slightly from those considered here in that their spines are very sturdy. It is not possible to determine accurately in all cases how many spines are present because all the spines were not always preserved intact in the material studied. All of these similar forms with spines varying in number from three to six are considered as one very variable species.

No species is known to have been described by Rüst with the specific name acanthophorum. Therefore the variety name triacanthus is considered as a specific name and used here for the species with multiple spines described above. 
The very rare early forms found in 196-5, CC and more commonly in 196-4-1, piece 3 tend to have the majority of the specimens with three spines while later forms in 196-3-1, piece 3 have the majority of specimens with four spines.

One specimen from 196-4-1, piece 3 with seven spines (Plate 16, Figure 13) is excluded.

Specimens of $P$. triacantha with three spines may be distinguished from $P$. tetracola by the character of the abdominal spines.

$P$. triacantha may very probably be conspecific with the two species illustrated by Lozyniak from the Neocomian of the Ukrainian Carpathians. However, the generic assignment and the lack of a written description for these forms leave some doubt. It may be related to Eusyringium typicum Rust, 1885 and $E$. affine Rust (1885). However, it differs from both in having a smaller horn and larger pores.

The varieties of Theosyringium acanthophorum Rüst described by Fischli are from the probable Cretaceous of the Rigi in Switzerland, Staurostylus sp. and Stylostaurus sp. from the Neocomian of the Ukrainian Carpathians, USSR, and E. typicum and E. affine from the Upper Jurassic of Cittiglio, northern Italy.

\section{Podobursa tricola Foreman, new species} (Plate 13, Figure 9; Plate 16, Figure 12)

Description: The shell is of three segments. The cephalis and thorax together form a small, subhemispherical, proximal part and the globose abdomen with terminal tube, the major distal portion. Preservation makes it difficult to distinguish the two proximal segments individually; apparently there is a small poreless cephalis bearing a bladed horn. The cephalis merges into the thorax with little or no external change in contour, and the thorax has uniform, small, closely spaced pores. The globose abdomen has large generally irregular pores which are sometimes subdivided. It bears three, rarely four, outward-directed spines, bladed basally and sometimes weakly bladed distally. The long slender tube with pores similar to those of the rest of the abdomen terminates in a spine.

Measurements (based on 10 specimens from 196-4-1, piece 3 and 196-3-1, piece 2). Estimated length overall, 290-325 $\mu$; length of cephalis and thorax together, $37-60 \mu$ (majority $40-45 \mu$ ); of abdomen without terminal tube, $85-115 \mu$; width of abdomen, $110-140 \mu$.

Remarks: This species may be distinguished from Podobursa triacantha by its smaller size and two proximal segments with subhemispherical shape.

Etymology: Greek trikolos - on $=$ tricolus, $-a,-u m$ three membered.

\section{Genus PODOCAPSA Rust emend. Foreman}

Podocapsa Rüst, 1885 , p. 304 . Type species (subsequent designation by Campbell, 1954, p. D122) Podocapsa guembelii Rüst, 1885 Remarks: When Campbell (1954, p. D122) subsequently designated Podocapsa guembelii Rust, 1885 as the type species of Podocapsa, he did not, in the absence of a type designation by Rust, indicate which of the two entirely different specimens illustrated by Ruist was to be considered as the lectotype of $P$. guembelii. He did reproduce one of Rust's illustrations, fig. 5 on pl. 36 . However, since he very frequently selected a specimen other than the one or more which were eligible to be the type of the species designated as type species of the genera he treated, this illustration by Campbell is not considered to be a designation. We therefore designate Rust's specimen (Plate 36, Figure 6) as the lectotype of Podocapsa guembelii.

Although Rust considered this specimen to be a monocyrtid with two porous wings and a porous apical extension, it is apparent that the latter is actually the terminal tube of the distalmost segment and that the proximal segments have been broken off. The generic definition of Podocapsa is thus emended as follows: Shell of at least three segments, the proximal part small, made up of all but the distalmost segment which is large, globose, and bears three porous wings and a porous terminal tube.
Podocapsa amphitreptera Foreman, new species (Plate 13, Figure 11)

Description: The shell is, probably, of three segments, a hemispherical, small, proximal part composed of cephalis and thorax, although no segmental division has been observed, and a large globose abdomen with terminal tube. The cephalis lacks a horn, and the pores of the first two segments are small and irregular in shape and arrangement. The large globose abdomen has large fairly uniform pores in circular to subangular pore frames; frequently, they are scalloped and sometimes subdivided in their lower margins. Three conical porous wings, terminating in a spine, extend outwards. Pores on the wings are irregularly arranged, rounded, only slightly smaller than those of the abdomen. The terminal tube is very variable in length, bears pores similar to those of the abdomen, and on one specimen was observed to end in a short blunt spine.

Measurements (based on 10 specimens from 196-5, CC). Length overall (one specimen only), $372 \mu$; of abdomen, 140-170 $\mu$; of wings (only two complete), 150 and $200 \mu$; width of abdomen, $170-250 \mu$ (majority $215-250 \mu$ ) of wing near base, $62-85 \mu$.

Remarks: Although this species is very rare in the material studied, it is described because of its distinctive easily recognizable form and because it is present only in 196-5, CC, the oldest sample containing Radiolaria.

Etymology: Greek amphitres porous + pteron $\mathrm{n}$. wing $=$ amphitrepterus, $-a,-u m$ porous winged.

\section{SETHOCAPSA Haeckel, 1881}

Sethocapsa Haeckel, 1881 , p. 433. Type species (here designated) Sethocapsa cometa (Pantanelli) in Rüst, 1885.

Remarks: Campbell (1954, p. D128) considers Sethocapsa to be an objective synonym of Adelocyrtis Pantanelli (1880) and therefore infers that the type species of Adelocyrtis, Adelocyrtis pala Pantanelli (1880) is also the type species of Sethocapsa. However, Adelocyrtis pala was not among the species first subsequently assigned to Sethocapsa and thus Sethocapsa cannot be an objective synonym of Adelocyrtis.

In the absence of any other known deisgnation of type species for Sethocapsa, the type designation is made, as indicated above, from among those species first subsequently assigned to Sethocapsa.

Included are all Mesozoic species with a large, globose, closed terminal segment without tube or spines, exclusive of the cryptocephalic and cryptothoracic nassellaria. These nassellarians, although common, were not treated in this chapter because the poor preservation made it difficult to study the internal cephalic and thoracic structures.

\section{Sethocapsa cetia Foreman, new species}

(Plate 12, Figure 1; Plate 16, Figure 19)

cf. Lithobotrys uva Ruist, 1885 , p. 301 , pl. 35 , fig. 2 .

cf. Stichocapsa conosphaeroides Rüst, 1898, p. 66, pl. 19, fig. 3 .

Description: The shell is extremely large, of approximately five segments, with a very large, globose terminal segment without aperture. The cephalis is poreless without an apical spine and, in one view, appeared to have internally a branched vertical spine as illustrated in Foreman (1966, text-figures 4-6). The approximately three postcephalic segments before the terminal one form a conical section with a rough surface of small rounded pores, irregular in size and distribution. Sometimes the individual segments are expanded and the dividing strictures can be distinguished. Generally, however, they are obscured by the thick shell wall. The terminal segment has a nodose rough surface with small rounded pores, irregular in size and distribution. It may be almost spherical or flattened apically.

Measurements (based on 10 specimens from 196-5, CC). Length, 445-550 $\mu$; maximum width of shell, $330-440 \mu$.

Remarks: This species differs from Lithobotrys uva Rust (1885) in its larger size and more numerous nodes, and from Stichocapsa conosphaeroides Rust, 1898 in its considerably larger size and less regular pores. L. uva Rüst is reported from the Late Jurassic Aptychus shale of Germany and Stichocapsa conosphaeroides from the Late Jurassic Aptychus beds of northern Italy.

Etymology: Greek ketos $\mathrm{m}$. sea monster + -ios related to $=$ cetius, $-a,-u m$ monstrous. 
Sethocapsa leiostraca Foreman, new species (Plate 12, Figures 5 and 6

Sethocapsa spinosa Vinassa, 1889, p. 233, pl. 18, fig. 16 (junior homonym of $S$. spinosa Parona, 1890)

Description: The shell is of probably three segments, a very small, conical, proximal part composed of cephalis and thorax and a large globose terminal segment without aperture. The cephalis is poreless and bears a short, conical, broad-based horn. The small thorax has a few small pores and is roughened by ridges which extend up from the abdomen. The abdomen is almost spherical, only slightly broader than high. It bears widely spaced, slender, short spines which arise from arches developed from the intervening pore bars, about five spines on a circumference. Pores are large, rounded, fairly regular, and tend to be scalloped or subdivided on their lower margins.

Measurements (based on 11 specimens from 195B-2, CC, $196-4-1$, piece 3 and $196-3-1$, piece 3 ). Length overall exclusive of apical horn, $210-325 \mu$ (majority $210-285 \mu$ ); of abdomen, $155-275 \mu$ (majority 170-250 $\mu$ ); width of globose terminal segment, $165-300 \mu$ (majority $165-250 \mu$ ); diameter of pores, $15-30 \mu$.

Remarks: This species differs from $S$. trachyostraca in lacking nodes and having larger pores.

Sethocapsa spinosa Vinassa (1899) is reported from the Tithonian of northern Italy.

Etymology: Greek leios smooth + ostrakon $\mathrm{n}$. shell = leiostracus, $-a$, - um with a smooth shell.

\section{Sethocapsa trachyostraca Foreman, new species (Plate 12, Figure 4)}

Description: The shell is of four segments, a cephalis and two postcephalic segments forming a small, conical, proximal part and a large globose terminal segment without aperture. The cephalis is poreless and bears a short, slender, cylindrical apical horn. The first postcephalic segment has few or no pores and the second, numerous, closely spaced, regular, rounded pores. The large globose terminal segment has a nodose surface with a short, slender, cylindrical spine, similar to the apical horn, extending from the apex of many of the nodes. Pores are moderate in size, rounded, slightly irregular, and tend to be scalloped or subdivided on their lower margin.

Measurements (based on 10 specimens from 196-4-1, piece 3 and 196-3-1, piece 3). Length overall exclusive of apical horn, 170-300 $\mu$ (majority 200-300 $\mu$ ); of globose terminal segment, 150-210 $\mu$; width of globose terminal segment, $140-245 \mu$ (majority 185-245 $\mu$ ); diameter of pores, $10-15 \mu$.

Remarks: This species differs from $S$. leiostraca as described under that species.

Etymology: Greek trachys rough + ostrakon n. shell = trachyostracus, $-a,-u m$ with a rough shell.

\section{Genus SYRINGOCAPSA Neviani, 1900}

Syringocapsa Neviani, 1900, p. 662. Type species (by monotypy) Theosyringium robustum Vinassa, 1900.

Trisyringium Vinassa, 1901-1902, p. 507. Type species (subsequent designation by Campbell, 1954 , p. D142) Trisyringium capellini Vinassa, 1901-1902.

Remarks: Trisyringium capellini. and Theosyringium robustum differ from each other only in that $T$. capellini bears a horn. This is not considered a significant character at the generic level and the two genera with similar type species are thus synonymized.

\section{Syringocapsa agolarium Foreman, new species (Plate 11, Figure 5; Plate 16, Figure 17)}

Description: The shell is of three segments, a proximal small hemispherical portion made up of the cephalis and thorax, and the major distal part consisting of a globose abdomen with a very variably developed terminal tube. The cephalis and thorax cannot always be distinguished by an external change in contour, and only rarely can any internal segmental division be discerned. The cephalis is apparently poreless and bears a slender, relatively moderate to long, smooth, oblique apical horn. The thorax may be poreless or have small irregular pores. The large abdomen is generally slightly flattened apically with small, closely spaced, regular pores with subangular pore frames. Some specimens bear widely spaced, short, sharp thorns. The closed tube may be conical when long to almost hemispherical when short, and terminates in a spine. Its pores are angular, regular, and markedly larger than those of the abdomen.

Measurements (based on 10 specimens from 196-4-1, piece 3 and 196-3-1, piece 3). Length overall, 225-350 $\mu$; of cephalis and thorax, $45-50 \mu$; of abdomen without terminal tube, $125-165 \mu$; of tube, 50-110 $\mu$; width of abdomen, $130-170 \mu$.

Remarks: This species differs from Trisyringium capellini Vinassa (1901-1902) in its larger size and in having relatively smaller, more closely spaced pores. $T$. capellini Vinassa is reported from the probable Upper Cretaceous of the island of Karpathos, Greece.

Etymology: Latin agolum n. shepherd's staff + arius having = agolarius $-a,-u m$, having a shepherd's staff.

\section{Syringocapsa limatum Foreman, new species}

(Plate 11, Figures 6 and 7; Plate 16, Figure 8)

Description: The shell is large with a sturdy, long, smooth apical horn, a slender proximal portion, and a large, globose, nodose abdomen without spines and with a closed terminal tube. It is not possible to determine the number of segments since the proximal part shows no external segmental division and preservation does not allow the interior to be observed. It is probable that the older forms with a longer proximal part may have more than two. Pores of the proximal part are small, rounded, and irregular in size and arrangement. Those of the large globose segment are moderate in size with rounded to subangular pore frames, very closely spaced. On the older specimens they are irregularly arranged and on the younger ones tend to be aligned in rows between nodes. The tube is long, slender, conical, with large regular pores, and terminates in a smooth pointed spine.

Measurements (based on 10 specimens from 196-5, CC, 196-4-1, piece 3 and 196-3-1, piece 3). Length overall of six complete specimens, 495-560 $\mu$; estimated length of largest broken specimen, $650 \mu$; length of horn and proximal segments, $160-255 \mu$ (majority $160-185 \mu)$; length of abdomen exclusive of tube, $155-195 \mu$; greatest width of abdomen, $185-240 \mu$ (majority $185-215 \mu$ ).

Remarks: Sethocapsa polymasta Rust (1898) from the Upper Jurassic of Cittiglio in northern Italy appears to be a related form. However, it differs in having a longer proximal part with only a small apical horn and in lacking a tube.

Etymology: Latin limatus, -a, -um elegant.

\section{ACKNOWLEDGMENTS}

The writer wishes to thank Dr. A.L. Brigger whose excellent preparations of the very difficult Early Cretaceous material aided significantly in producing this report, Dr. J. Helms for help in composing suitable names for new taxa, Mr. A. White for the excellent scanning electron microscope pictures he provided, and Mrs. M. Brittingham and Mrs. J. Gilbert for assistance in the final compilation and typing of the manuscript.

The writer wishes also to thank the National Science Foundation which through the Deep Sea Drilling Project provided some financial support, and the Citgo Oil Company which made its scanning electron microscope facilities available.

\section{REFERENCES}

Aliev, Kh. Sh., 1961. Novye vidy radioliarii nizhnego melo severovostochnogo Azerbaidzhana. (New radiolarian species of the Lower Cretaceous of northeastern Azerbaidzhan.): Uu. Zap. Izd. Azerbadiz. G. Univ., Ser. Geol.-Geogr., No. 2.

1965. Radioliarii nizhnemelovykh otozhenii severo-vostochnogo Azerbaidzhana i ikh stratigraficheskoe znachenie. (Radiolarians of the Lower Cretaceous deposits of northeastern Azerbaidzhan and their stratigraphic significance.): Izd. Akad. Nauk Az. SSR, Baku. 
Bailey, J.W., 1856. Notice of microscopic forms found in the soundings of the Sea of Kamtschatka-with a plate. Am. J. Sci. Ser. 2, V. 22(64), p. 1.

Blow, W.H., 1969. Late middle Eocene to Recent planktonic foraminiferal biostratigraphy: Inter. Conf. Plankt. microfossils, 1st, Geneva, 1967, Proc., Brönnimann, P. and Renz, H.H. (Eds.), V. 1, p. 199.

Bukry, D. and Bramlette, M.N. 1969. Coccolith age determinations Leg 1, Deep Sea Drilling Project, In Ewing, M., Worzel, J.L., et al., Initial Reports of the Deep Sea Drilling Project, Volume I: Washington (U.S. Government Printing Office), p. 369.

Campbell, A.S., 1954. Radiolaria. In Treatise on Invertebrate Paleontology, Moore, R.C. (Ed.): Univ. Kansas Press and Geol. Soc. Am., pt. D. Protista, v. 3, p. 11.

Campbell, A.S. and Clark, B.L., 1944. Radiolaria from Upper Cretaceous of middle California: Geol. Soc. Am., Spec. Paper 57, p. 61.

Cita, M.B. and Pasquaré, G., 1959. Osservazioni micropaleontogiche sul Cretaceo delle dolomiti. Riv. Ital. Paleontol. Stratigr., v. 65(4), p. 385.

Davis, A.G., 1950. The Radiolaria of the Hawasina Series of Oman. Geol. Assoc. London Proc., v. 61(3), p. 206.

DeFlandre, G., 1953. Radiolaries fossiles. In Traité de Zoologie, Grassé, P.-P. (Ed.): Paris (Masson), v. 1(2), p. 389.

Dumitrica, P., 1970. Cryptocephalic and cryptothoracic Nassellaria in some Mesozoic deposits of Romania: Rev. Roum. Géol., Géophys., Géogr., Ser. Géol., v. 14(1), p. 45 .

Dundo, O.P. and Zhamoida, A.I., 1963. Stratigrafiia mezozoiskikh otlozhenii basseina r. velikoi i kharakternyi kompleks valanzhinskikh radioliarii. (Stratigraphy of the Mesozoic deposits of the Velikaya River Basin and the characteristic complex of Valanginian radiolarians.) In Geologiia Koriakskogo nagor'ia (Geology of the Koryaksk highland), Egiazarov, B. Kh. (Ed.): Moscow (Nauch.-Issled. Inst. Geol. Arktiki). p. 64.

Dunikowski, E., 1882. Die Spongien, Radiolarien und Foraminiferen der unterliassischen Schichten vom Schafberg bei Salzburg: Denkschr. Kaiserl. Akad. Wiss. Wien, math.-naturwiss, C1. 45, p. 163.

Ehrenberg. C.G., 1875. Fortsetzung der mikrogeologischen Studien als Gesammt-Uebersicht der mikroskopischen Paläontologie gleichartig analysirter Gebirgsarten der Erde, mit specieller Rücksicht auf den PolycystinenMergel von Barbados: Abh. Kgl. Akad. Wiss. Berlin, Jahre 1875 , p. 1 .

Fischli, H., 1916. Beitrag zur Kenntnis der fossilen Radiolarien in der Riginagelfluh: Mitt. Naturwiss. Ges. Winterthur. v. 11, p. 44.

Foreman, H.P., 1966. Two Cretaceous radiolarian genera: Micropaleontology. v. 12(3), p. 355

1971. Cretaceous Radiolaria. In Winterer, E.L., Riedel, W.R., et al., Initial Reports of the Deep Sea Drilling Project, Volume VII: Washington (U.S. Government Printing Office), p. 1673.

Haeckel, E., 1881. Entwurf eines Radiolarien-Systems auf Grund von Studien der Challenger-Radiolarien. Jena. Z. Med. Naturwiss., v. 15 (New Ser. 8(3)), p. 418.

Hays, J.D., 1965. Radiolaria and Late Tertiary and Quaternary history of Antarctic seas. In Biology of the Antarctic Seas II: Antarctic Res. Ser. 5 (Am. Geophys. Un.), p. 125.

1970. Stratigraphy and evolutionary trends of Radiolaria in north Pacific deep-sea sediments: Geol. Soc. Am., Mem. 126, p. 185.
Heitzer, I., 1930. Die Radiolarienfauna der mitteljurassischen Kieselmergel im Sonnwendgebirge: Jahrb. Geol. Bundesanst., v. 30, p. 381 .

Hinde, G.J., 1900. Description of fossil Radiolaria from the rocks of central Borneo, obtained by Prof. Dr. G.A.F. Molengraaff in the Dutch Exploring Expedition of 1893-1894. In Borneo Expeditie. Geologische Verkenningstochten in Centraal-Borneo (1893-94), G.A.F. Molengraaff: Leiden (H. Gerlings), Append. I.

Holmes, W.M., 1900. On Radiolaria from the Upper Chalk at Coulsdon (Surrey). Geol. Soc. London., Quart. J., v. 56 , p. 694.

Kling, S.A., 1971. Radiolaria. In Fischer, A.G., Heezen, B.C., et al., Initial Reports of the Deep Sea Drilling Project, Volume VI: Washington (U.S. Government Printing Office), p. 1069.

1973. Radiolaria from the eastern north Pacific. In Kulm, L.D., von Huene, R., et al., Initial Reports of the Deep Sea Drilling Project, Volume XVIII: Washington (U.S. Government Printing Office).

Klunzinger, C.B., 1877. Die Korallthierre des rothen Meeres, Part I: Berlin (O. Ensln).

Ling, H.-Y., 1972. Upper Cretaceous and Cenozoic silicoflagellates and ebridians: Bull. Am. Paleontol., v. 62(273), p. 135

Lipman, R. Kh., 1960. Subclass Radiolaria. In Stratigrafiya i fauna melovykh otlozhenii zapadnosibirskoi nizmennosti. (Stratigraphy and fauna of the Cretaceous deposits in the western Siberian lowlands.): Glazunova, A.E., (Ed.), Tr. VSEGEI, New Ser., v. 29, p. 124.

Loeblich, A.R. and Tappan, H., 1961. Remarks on the systematics of the Sarkodina (Protozoa), renamed homonyms and new and validated genera: Biol. Soc. Wash. Proc., v. 74 , p. 213.

Lozyniak, P. Yu., 1969. Radioliarii nizhnemelovykh otlozhenii Ukrainskikh Karpat. (Radiolaria of the Lower Cretaceous sediments of the Ukrainian Carpathians.) In Iskopaemye i Sovremennye Radioliarii (Fossil and Recent radiolarians), Vialov, O.C. (Ed.): L'vov. Geol. O-vo., L'vov. Univ., p. 29.

Neviani, A., 1900. Supplemento alla fauna a radiolari delle rocce mesozoiche del Bolognese: Soc. Geol. Ital. Boll. v. 19 , p. 645.

Nigrini, C.A., 1971. Radiolarian zones in the Quaternary of the equatorial Pacific Ocean. In Micropaleontology of the Oceans, Funnell, B.M. and Riedel, W.R. (Eds.): Cambridge (Cambridge Univ. Press). p. 443.

Pantanelli, D., 1880. I diaspri della Toscana e i loro fossili: Atti, Mem. R. Accad. Lincei., Ser. 3, v. 8, p. 35.

Parona, C.F., 1890. Radiolarie nei noduli selciosi del calcare giurese di Cittiglio presso Laverno. Soc. Geol. Ital. Boll., v. 9 , p. 132 .

Parona, C.F. and Rovereto, G., 1895. Diaspri permiani a radiolarie di Montenotte (Liguria Occidentale): Atti R. Accad. Sci. Torino, Cl. Sci. fis., mat. natur., v. 31, p. 167.

Pessagno, E.A., Jr., 1969. Mesozoic planktonic foraminifera and Radiolaria. In Ewing, M., Worzel, J.L., et al., Initial Reports of the Deep Sea Drilling Project, Volume I: Washington (U.S. Government Printing Office), p. 607. 1971. Jurassic and Cretaceous Hagiastridae from the Blake-Bahama Basin (Site 5A, JOIDES Leg I) and the Great Valley sequence, California Coast Ranges: Bull. Am. Paleontol., v. 60(264), p. 1.

1972. Pseudoaulophacidae Riedel from the Cretaceous of California and the Blake-Bahama Basin (JOIDES Leg I). In Cretaceous Radiolaria: Bull. Am. Paleontol., v. 61(270), p. 281. 
In press. Upper Cretaceous Spumellarina from the Great Valley sequence, California Coast Ranges: Cont. No. 195, Geosci. Div., Univ. Texas, Dallas.

Petrushevskaya, M.G. and Kozlova, G.E., 1972. Radiolaria: Leg 14, Deep Sea Drilling Project. In Hayes, D.E., Pimm, A.C., et al., Initial Reports of the Deep Sea Drilling Project, Volume XIV: Washington (U.S. Government Printing Office), p. 495.

Riedel, W.R., 1967a. Some new families of Radiolaria: Geol. Soc. London Proc., No. 1640, p. 148.

1967b. Protozoa [Subclass Radiolaria]. In The Fossil Record, Harland, W.B. et al. (Eds.): London (Geol. Soc. London). p. 291.

Riedel, W.R. and Sanfilippo, A., 1970. Radiolaria. In Bader, R.G., Gerard, R.D., et al., Initial Reports of the Deep Sea Drilling Project, Volume IV: Washington (U.S. Government Printing Office), p. 503.

1971. Cenozoic Radiolaria from the western tropical Pacific. In Winterer, E.L., Riedel, W.R., et al., Initial Reports of the Deep Sea Drilling Project. Volume VII: Washington (U.S. Government Printing Office), p. 1539.

Rüst, D., 1885. Beiträge zur Kenntniss der fossilen Radiolarien aus Gesteinen des Jura: Palaeontographica, v. 31 , Ser. 3(7), p. 273.

, 1898. Neue Beiträge zur Kenntniss der fossilen Radiolarien aus Gesteinen des Jura und der Kreide: Palaeontographica, v. 45 , p. 1 .

Squinabol, S., 1903. Le Radiolarie die noduli selciosi nella scaglia degli Euganei: Contrib. I. Riv. Ital. Paleontol, v. 9(4), p. 105.

, 1913. Radiolari della strada nazionale al Monginevro: R. Com. Geol. Ital. Bal., v. 43 (ser. 5, 3) $(2-3)$, p. 281

1914. Contributo alla conoscenza dei Radiolarii fossili del Veneta. Appendice-Di un genere di Radiolari caratteristico del Secondario: Mem. Ist. Geol. R. Univ. Padova, v. 2, p. 249.

Tan Sin Hok. 1927. Over de samenstelling en het onstaan van krijt-en mergelgesteenten van de Molukken: Jaarb. Mijnw. Ned.-Oost-Indië, Jaarg. 1926, Verhand., Pt. 3, p. 5.

Turner, J., 1965. Upper Jurassic and Lower Cretaceous microfossils from the Hautes-Alpes: Palaeontology, v. $8(3)$, p. 391 .

Vinassa de Regny, P.E., 1899. I Radiolari delle ftaniti titoniane di Cárpene (Spezia): Palaeontogr. Ital., v.4 (1898), p. 217

— 1900. Rocce e fossili del dintorni di Grizzana e di Lagàro nel Bolognese: Soc. Geol. Ital. Boll., v. 19(2), p. 321 .

1901-02. Radiolari cretacei dell'isola di Karpathos: Mem. R. Accad. Sci. 1st. Bologna. Ser. 5, v. 9, p. 497.

Wiśniowski, T., 1889. Beitrag zur Kenntniss der Mikrofauna aus der oberjurassischen Feuersteinknollen der Umgegend von Krakau: Jahrb. Kaiserl.-Kgl. Geol. Reichsanst., Jahrg. 1888 , v. $38(4)$, p. 657.

Worsely, T.R., 1971. Calcareous nannofossil zonation of Upper Jurassic and Lower Cretaceous sediments from the western Atlantic: Planktonic Conf., 2nd, Rome, 1970 , Proc., v. 2 , p. 1301.

Yao, A., 1972. Radiolarian fauna from the Mino Belt in the northern part of the Inuyama Area, central Japan: J. Geosci., v. 15 , p. 21.

Zhamoida, A.I., 1969. Pervye rezul'taty izuchenia mezozoyskikh radioliarii Sakhalina. (First results of the study of Mesozoic Radiolaria on Sakhalin.) In Iskopaemye i sovremennye Radioliarii. (Fossil and Recent radiolarians), Vialov, O.C. (Ed.): L'vov. Geol. O-vo., L'vov. Univ. 17.

Zhamoida, A.I., et al., 1968. Kompleksy Mezozoyskikh Radioliarii vsstochio-Sakhalinskikh gor. (Complex of Mesozoic Radiolaria in the eastern Sakhalin mountains.) In Ezheg. Vses. Paleontol. Obshch. Modzalevskaya, E.A. (Ed.), v. 15, p. 24.

Zittel, K.A., 1876. Ueber einige fossile radiolarien aus der norddeutschen Kreide. Z. Deut. Geol. Ges., v. 28, p. 75.

\section{EXPLANATION OF PLATES}

It was not possible to obtain a scanning electron microscope picture of all the forms studied, and sometimes it seemed desirable to include a transmitted light picture in addition to the SEM photograph if this was believed to be useful. Therefore, both kinds of pictures are included on the plates.

It was also not possible to treat all the illustrated forms in the taxonomic section. For the species which have not been treated, or not assigned or compared to any previously described species, some discussion is generally given with the plate explanations.

Plates 1 to 13 illustrate the three Early Cretaceous assemblages informally defined herein. They are listed below from the youngest to oldest with levels from which pictures were taken.

Acaeniotyle tribulosa assemblage: The majority of forms come from the level at 194-5, CC; however it was not always possible to find a form suitable for illustration from this horizon and some forms come from the next higher sample, 194-4, CC. An illustration from this latter level is indicated visually by being mounted in the same row but slightly higher than the specimens from 194-5, CC. If the specimen was so large that it could not be raised, its level is indicated in the plate description. As indicated earlier, the absence of illustrations from this assemblage may be due to poor preservation, paucity of forms, and few samples available for study. Also, because of the poor preservation, a specimen suitable for photographing was not always found.

Sethocapsa trachyostraca assemblage: The majority of forms come from the level of 196-4-1, piece 3; however it was not always possible to find a form suitable for illustration from this horizon, and some forms are illustrated from the next higher horizon, 196-3-1, piece 3 . Some specimens are also included from this latter sample to show variation in form. Specimens from 196-3-1, piece 3 are indicated visually by being mounted in the same row but slightly higher than the specimens from 1964-1, piece 3.

Sethocapsa cetia assemblage: All specimens illustrated come from the level of $196-5, \mathrm{CC}$.

Plates 14 and 15 illustrate Radiolaria from two Late Cretaceous levels, Plate 14, Late Cretaceous, possibly 
Cenomanian, and Plate 15, Campanian. Plate 16 illustrates specimens, in addition to those on Plates 1 through 13, from the Early Cretaceous samples.

Magnifications of all the SEM pictures are $\times 112$ except for Plate 1, Figure 15, which is $\times 75$. Transmitted light pictures have been reproduced as close to the $X 112$ magnification of the SEM pictures as possible and range from $\times 100-\times 117$.

Type specimens are deposited in the United States National Museum, Washington, D. C. 
PLATE 1

Magnification: $\times 112$ for Figures 1, 2, 4-6, 9-13, 16; $\times 116$ for Figures 3, 7, 8; $\times 117$ for Figure 14; and $\times 75$ for Figure 15.

Figure 1

Figure 2

Figure 3-6

Figures 7-11

Actinommid, Gen. and sp. indet. sl. 1626-3-2A.

An ellipsoidal form present only in the Sethocapsa cetia assemblage.

Actinommid, Gen. and sp. indet. sl. 1592-2-4.

A discoidal form known only from the Sethocapsa trachyostraca assemblage. However absences of this relatively fragile form, above and below, may be due to poor preservation.

Actinommids, Gen. and sp. indet. Figures 3, 4, and 5 are ellipsoidal in form while Figure 6 is spherical. It is not certain whether the ellipsoidal forms are due to the distortion of originally spherical forms.

3. cs. $1 \mathrm{M} 38 / 2$.

4. sl. 1651-1-1.

5. sl. 1668-2-3.

6. sl. 1569-3-3.

Sphaerostylus lanceola (Parona) group.
7. sl. $5 \mathrm{~K} 18 / 2$.
8. cg. ph. $5 \mathrm{~L} 20 / 2$.
9. sl. 1670-1-2.
10. Illustrated specimen USNM 189035.
11. sl. 1626-2-1.

Figures 12-14, 16 Acaeniotyle umbilicata (Rüst).
12. sl. $1621-402$.
13. Illustrated specimen USNM 189034.
14. sl. T R $45 / 0$.
16. sl. 1592-3-7.

Figure 15 Acaeniotyle sp. aff. A. umbilicata (Rüst). sl. 1621-4-0. 


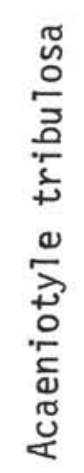
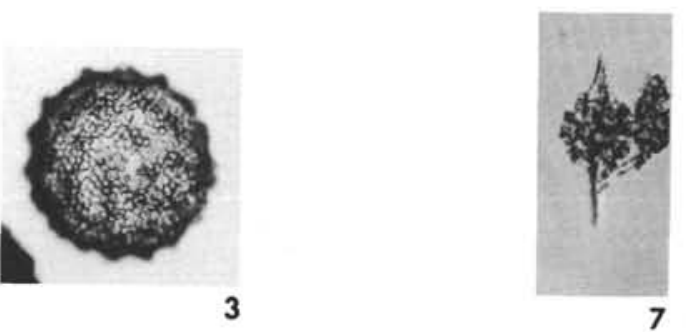

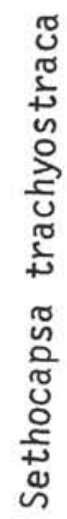

3
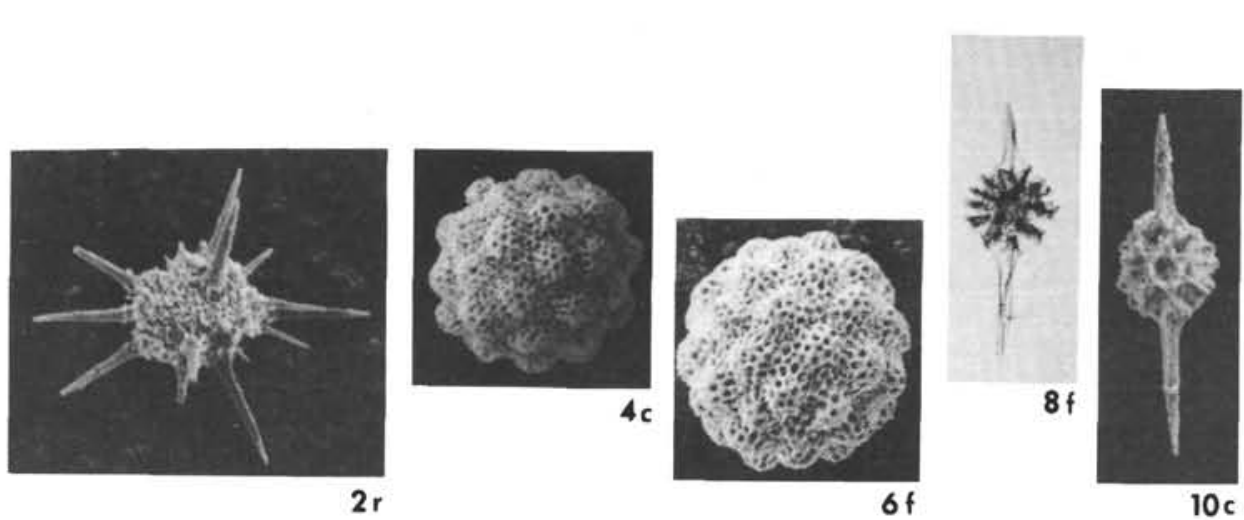

$12 f$
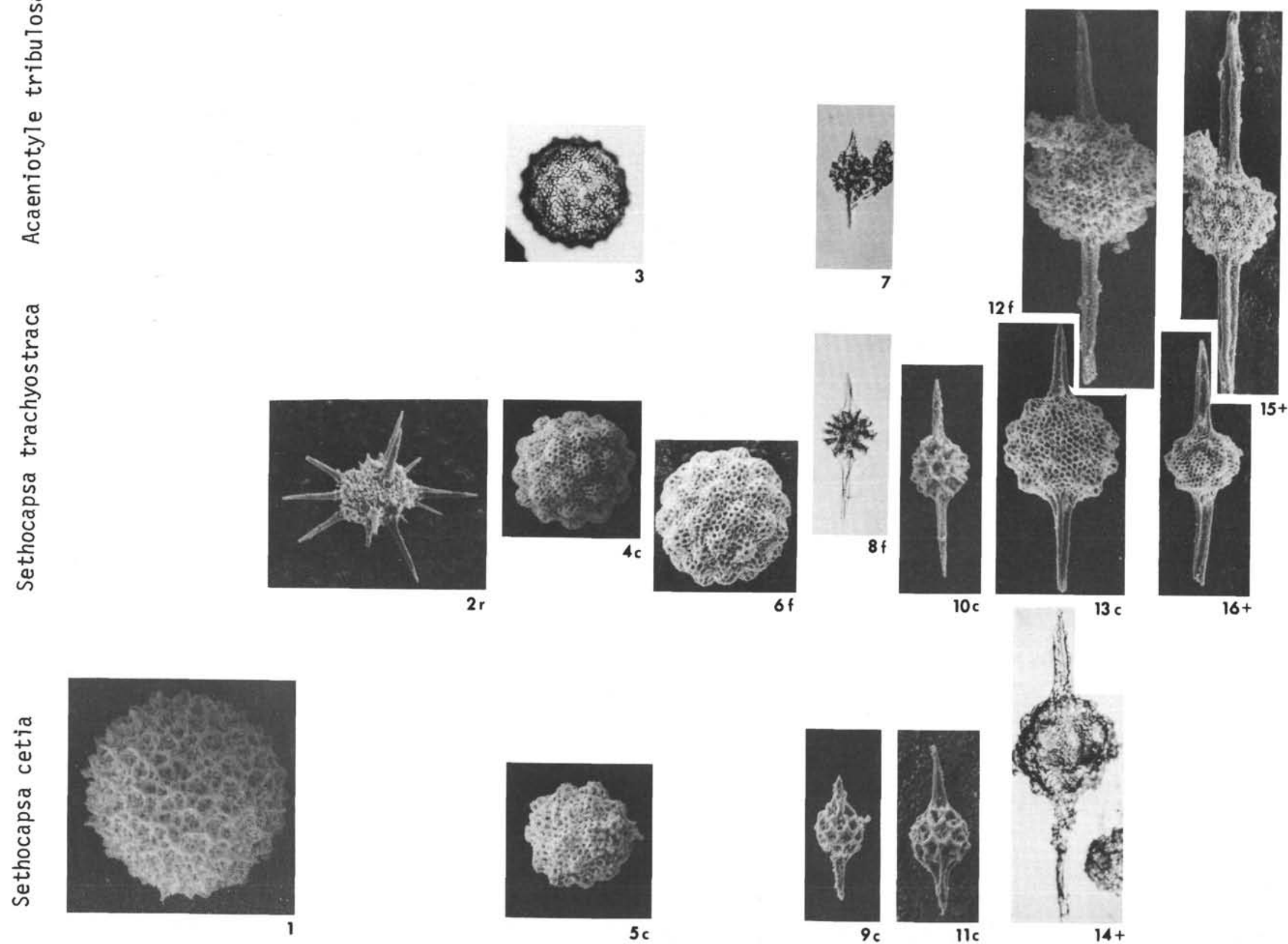
PLATE 2

Magnification: $\times 112$ for Figures 1, 3-10; $\times 117$ for Figure 2

Figure 1 Triactoma tithonianum Rüst.

Illustrated specimen USNM 189041.

Figures 2-5 Acaeniotyle diaphorogona Foreman n.sp.

2. cs. 2 T17/1;194-4, CC

3. Holotype USNM 189032.

4. sl. $1592-3-4$

5. sl. $1605-1-6 \mathrm{~A}$

Figures 6, 7 Acaeniotyle sp. aff. A. diaphorogona Foreman.

6. sl. 1661-1-2.

7. sl. $1592-3-3 \mathrm{~A}$

Figure 8 Acaeniotyle tribulosa Foreman n.sp.

Holotype USNM 189033.

Figures 9, 10 Triactoma cellulosa Foreman n.sp.

9. Holotype USNM 189039.

10. sl. $1462-2-3$. 


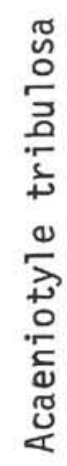
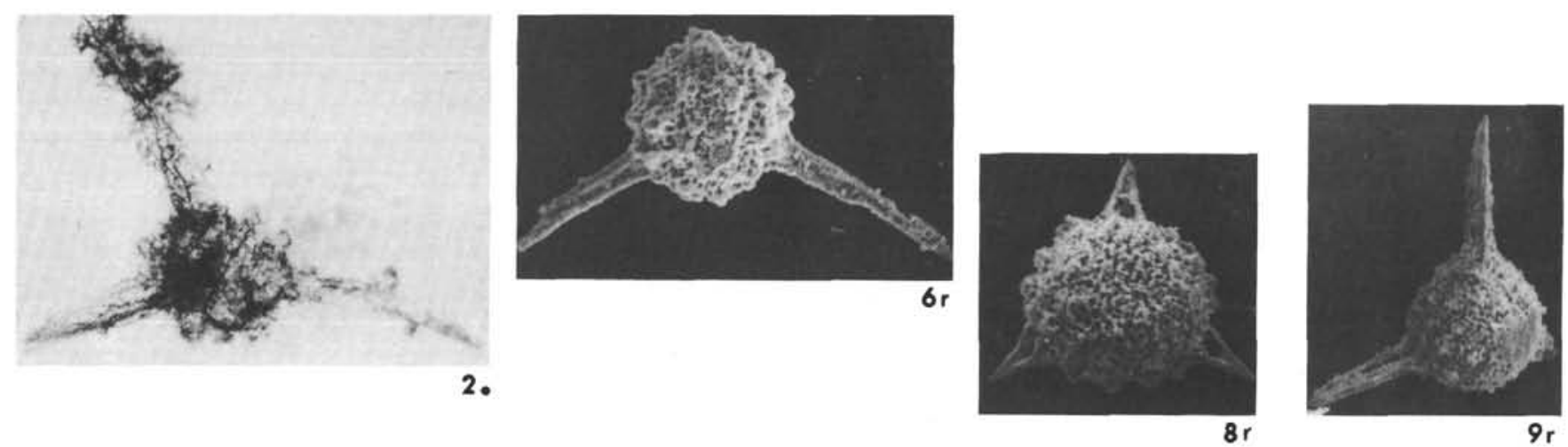

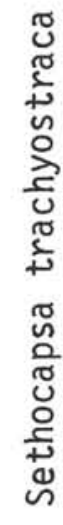
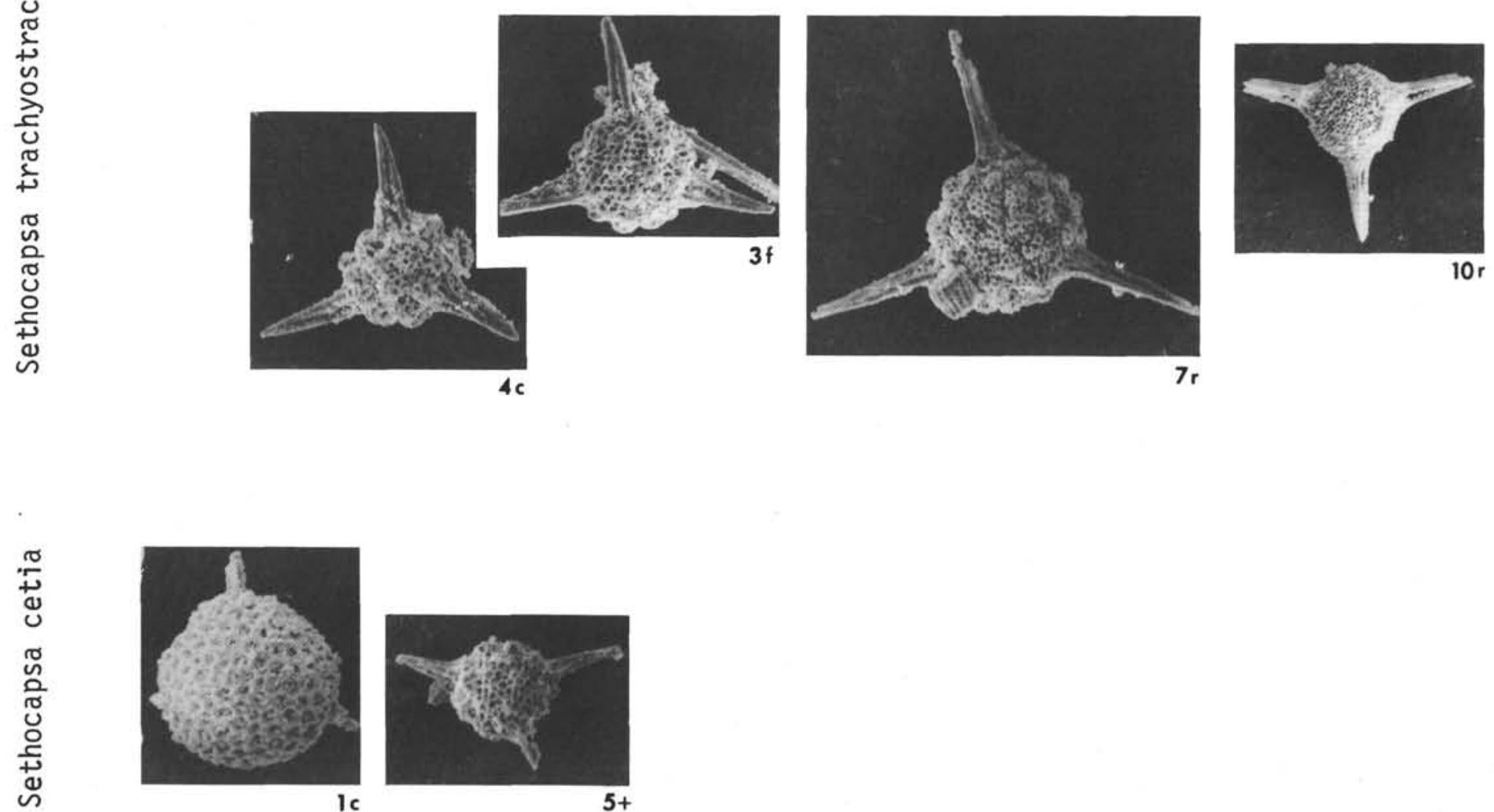


\section{PLATE 3}

Magnification: $\times 112$ for Figures 1, 3,4,6;

$$
\times 116 \text { for Figures } 2,5
$$

Figure 1 Triactoma echiodes Foreman n.sp.

Holotype USNM 189040.

Figures 2,3 Triactoma sp. cf. T. echiodes Foreman.

2. cg. sl. S G49/3.

3. sl. 1592-3-1.

Figure $4 \quad$ Staurosphaera septemporata Parona. Illustrated specimen USNM 189038.

Figure 5 Staurosphaera glebulosa Foreman n.sp. Holotype USNM 189037, G38/1.

Figure 6

Staurosphaera amplissima Foreman n.sp. Holotype USNM 189036; 194-4, CC. 

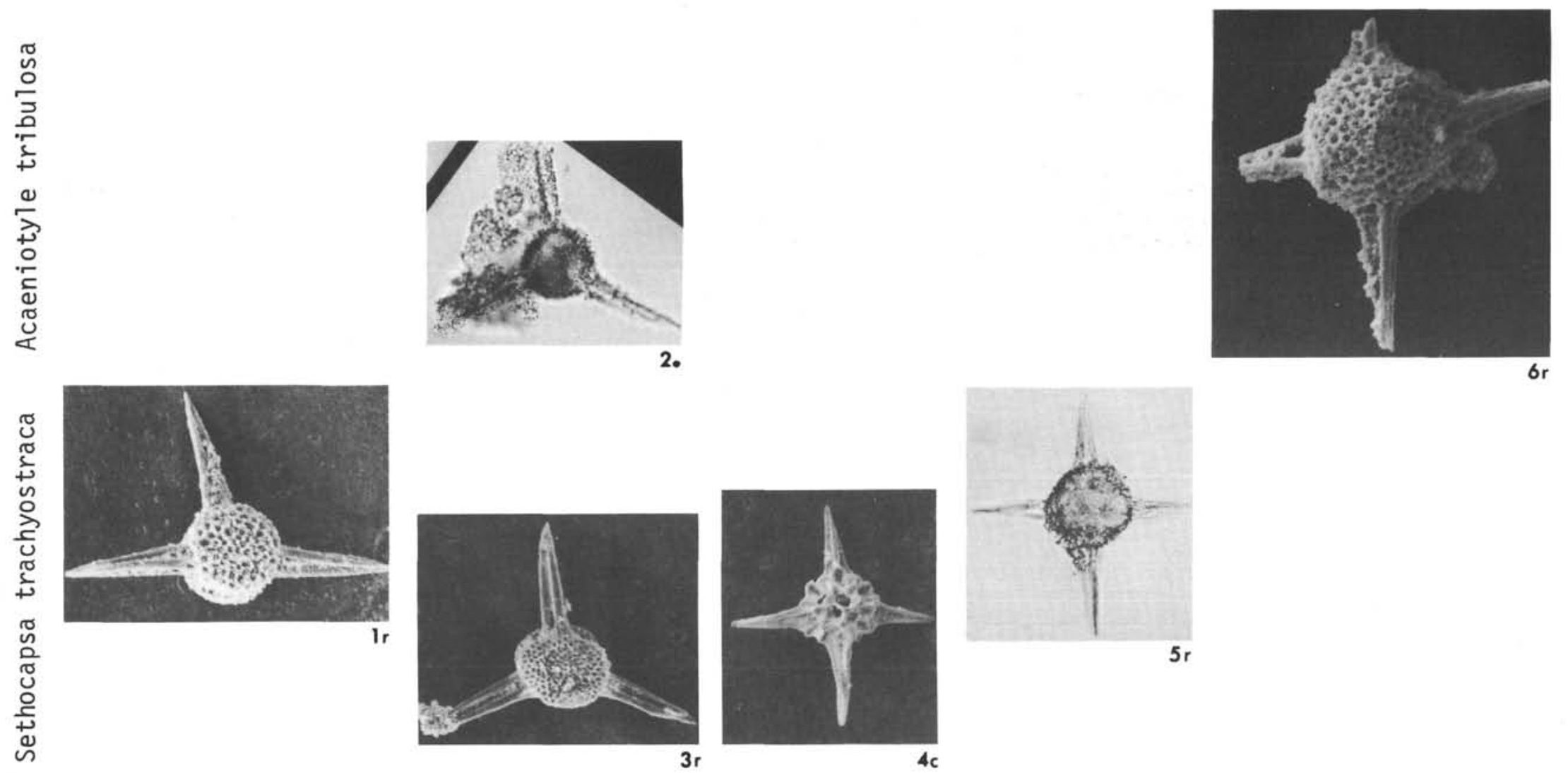

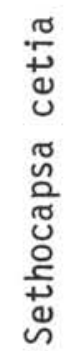




\section{PLATE 4}

Magnification: $\times 112$

Figure $1 \quad$ Spongosaturnalis (?) sp. aff. S. (?) aculeatus (Rüst). sl. $1661-3-3 ; 194-4$, CC.

Figure 2 Spongosaturnalis (?) aculeatus (?) (Rüst). sl. 1592-1-2.

Figure 3 Spongosaturnalis (?) sp. aff. S. (?) aculeatus (Rüst). sl. $1661-3 \cdot 2 ; 194-4$, CC

Figures 4, 5 Acanthocircus dizonius (?) (Rüst).

4. sl. 1592-1-4.

5. sl. 1626-1-2.

Figures 6-8 Acanthocircus trizonalis (?) (Rüst).

6. sl. 1661-3-1.

7. si. 1592-1-3.

8. sl. 1626-1-1. 

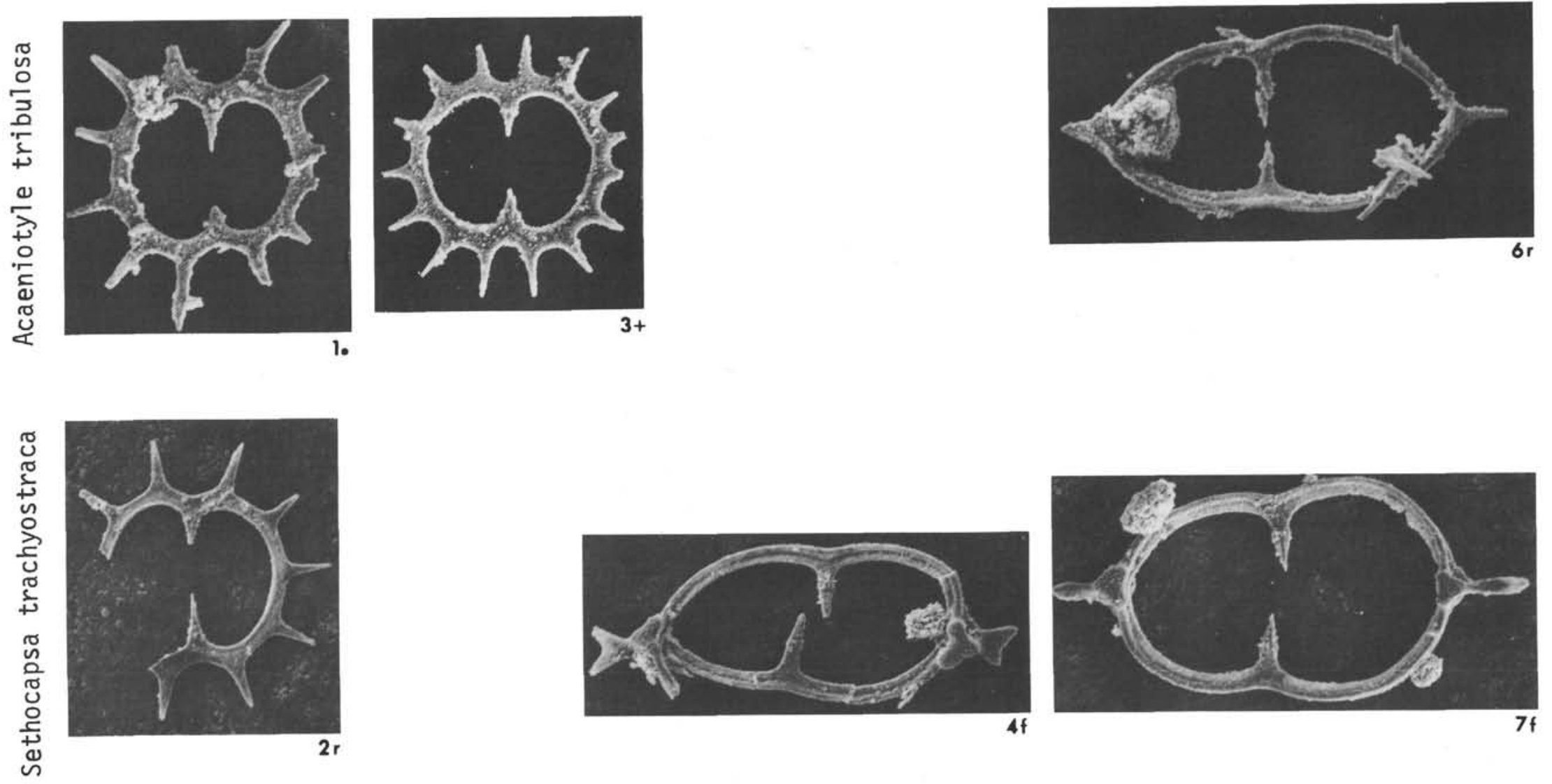

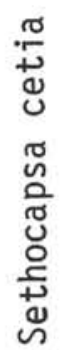
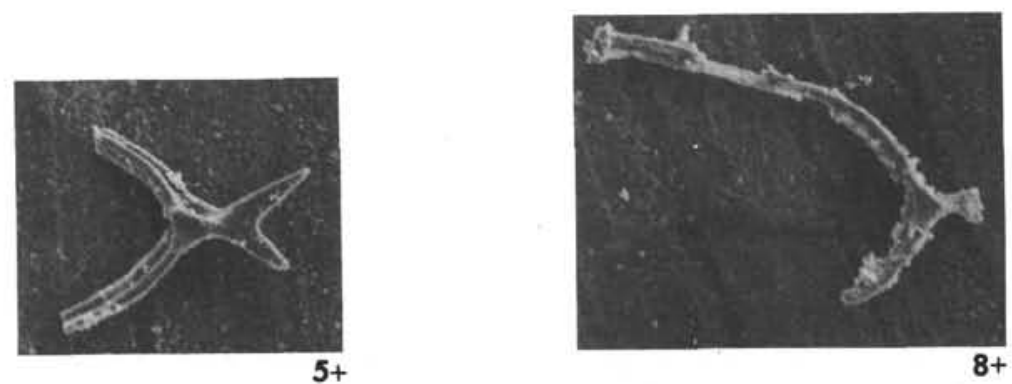
PLATE 5

Magnification: $X 117$ for Figures 1, 2, 4, 5; $\times 112$ for Figures $3,6-8$

Figures 1,2 Acanthocircus carinatus Foreman n.sp.

1. ph. R H20/0.

2. Holotype USNM 189042.

Figure 3 Transitional form? A. carinatus - A. sp. aff. $S$. variabilis Squinabol.

sl. 1592-1-6.

Figures 4, 5 Acanthocircus sp. aff. S. variabilis Squinabol.

4. sl. S S47/0;196-3-1, piece 2.

5. ph. R G18/3.

Figures 6-8 Hagiastrids. Gen. and sp. indet.
6. sl. 1462-2-2
7. sl. 1569-3-1.
8. sl. 1605-1-4. 


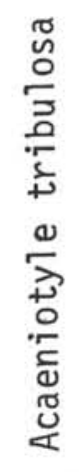
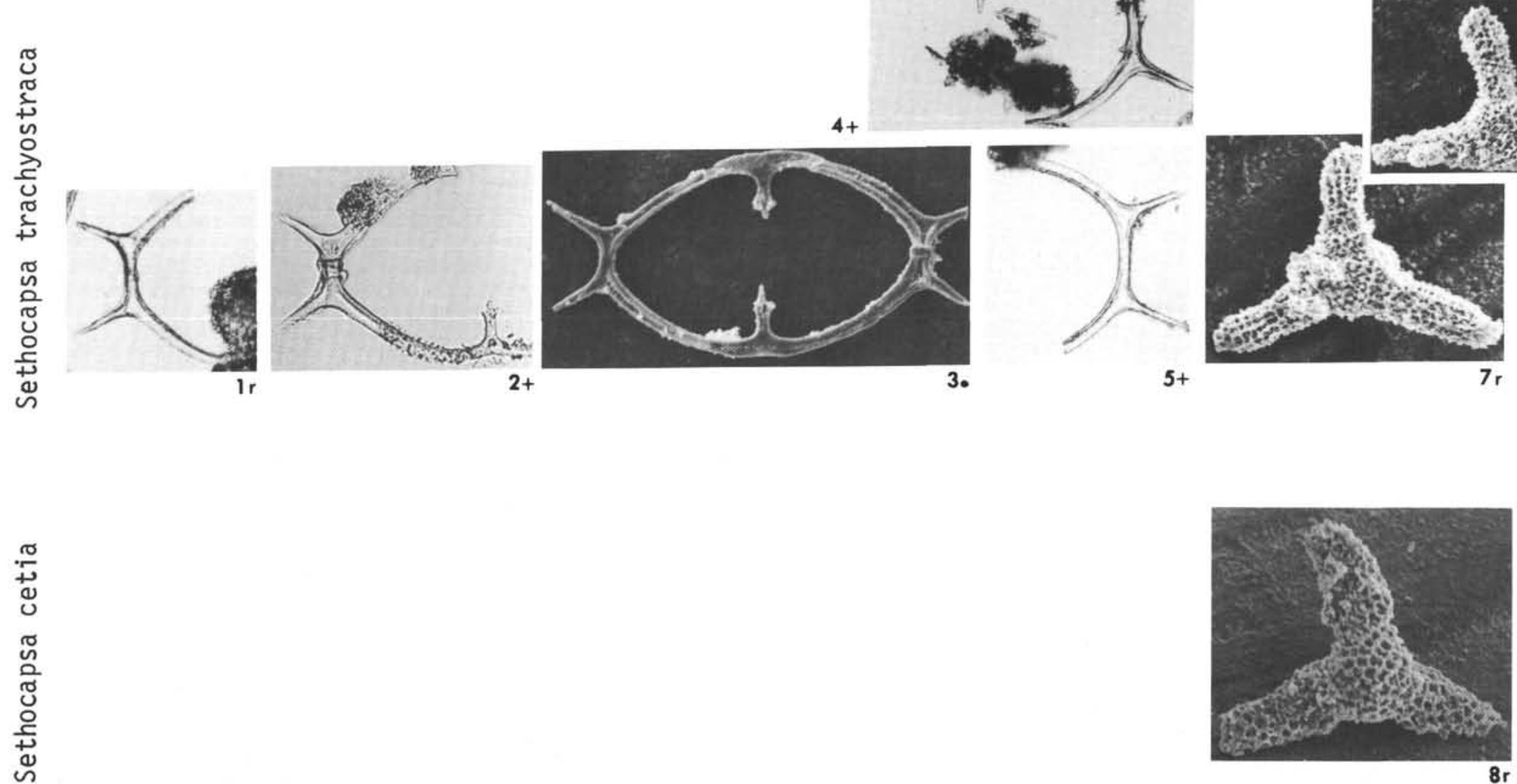


\section{PLATE 6}

Magnification: $\times 112$

Figures 1,2, 4 Hagiastrids(?). Gen. and sp. indet. Because their linear structure, if any, is not immediately evident, these

forms are only doubtfully included in the

Hagiastridae.

1. sl. 1605-1-3.

2. sl. $1638-5-4$

4. sl. $1670-1-4$.

Figures 3, 5, 6 Hagiastrids. Gen. and sp. indet.
3. sl. 1638-5-3.
5. sl. 1407-1-1
6. sl. 1614-2-8. 
0
0
0
3
0
$\vdots$
$+\infty$
0
0
+3
0
0
0
0
0
0

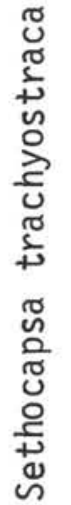
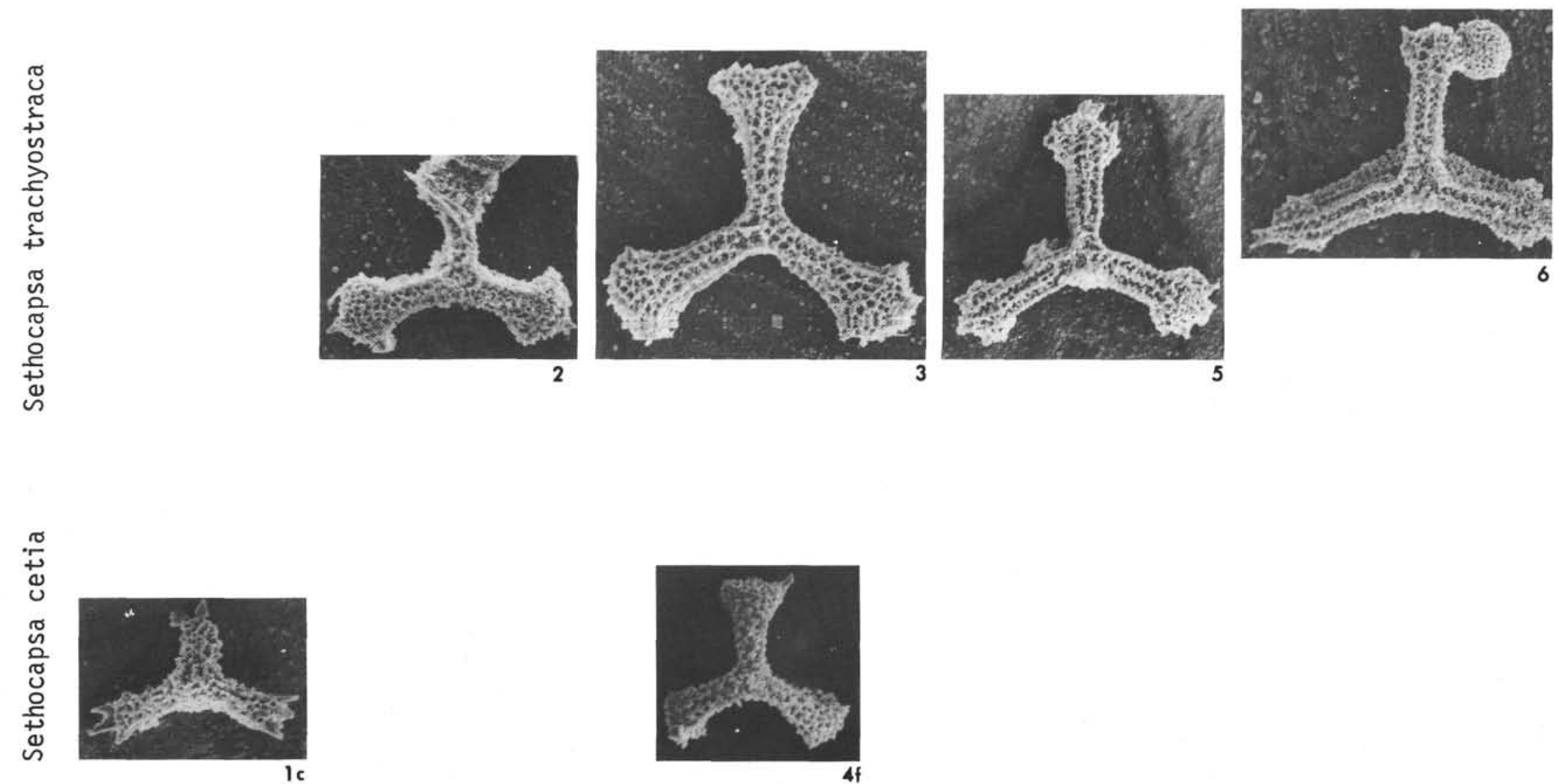
PLATE 7

Magnification: $\times 112$

Figures 1-7 Hagiastrids. Gen. and sp. indet.

1. sl. 1638-5-2.

2. sl. 1614-2-6.

3. sl. 1651-3-1.

4. sl. 1638-5-1

5. sl. 1605-1-2.

6. sl. 1621-5-1.

7. s. 1614-2-7. 


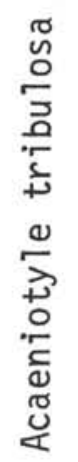
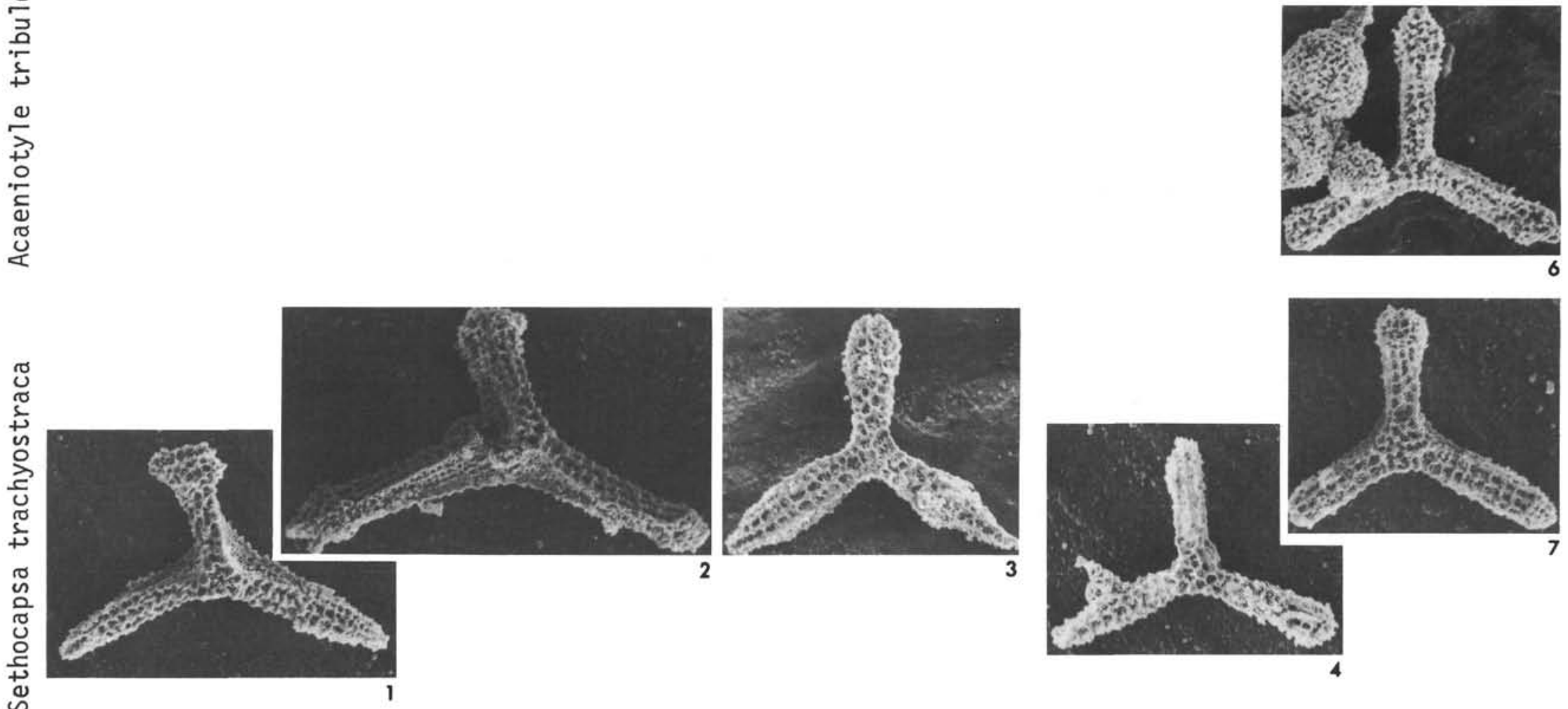

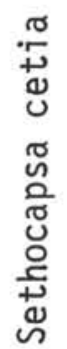

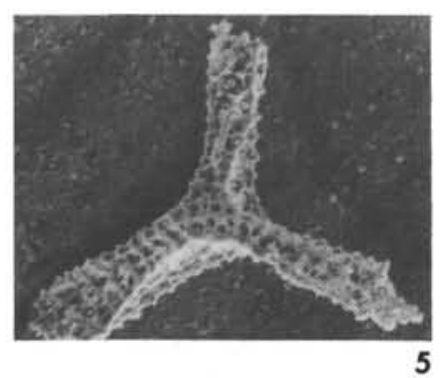




\section{PLATE 8}

Magnification: $\times 112$ for Figures 1-3, 6, 7;

$$
\times 116 \text { for Figures 4, } 5
$$

Figure $1 \quad$ Paronaella (?) ewingi (?) Pessagno. s. 1407-2-2.

Figure $2 \quad$ Paronaella (?) sp. sl. 1605-1-1.

Figures 3,4 Paronaella (?) diamphidia Foreman n.sp. 3. Holotype USNM 189043.

4. cs. R R52/4.

Figure $5 \quad$ Paronaella (?) sp. aff. P. diamphidia, Foreman. cs. U M27/0.

Figure 6 Emiluvia pessagnoi Foreman n.sp. Holotype USNM 189046.

Figure $7 \quad$ Emiluvia chica Foreman n.sp. Holotype USNM 189045. 

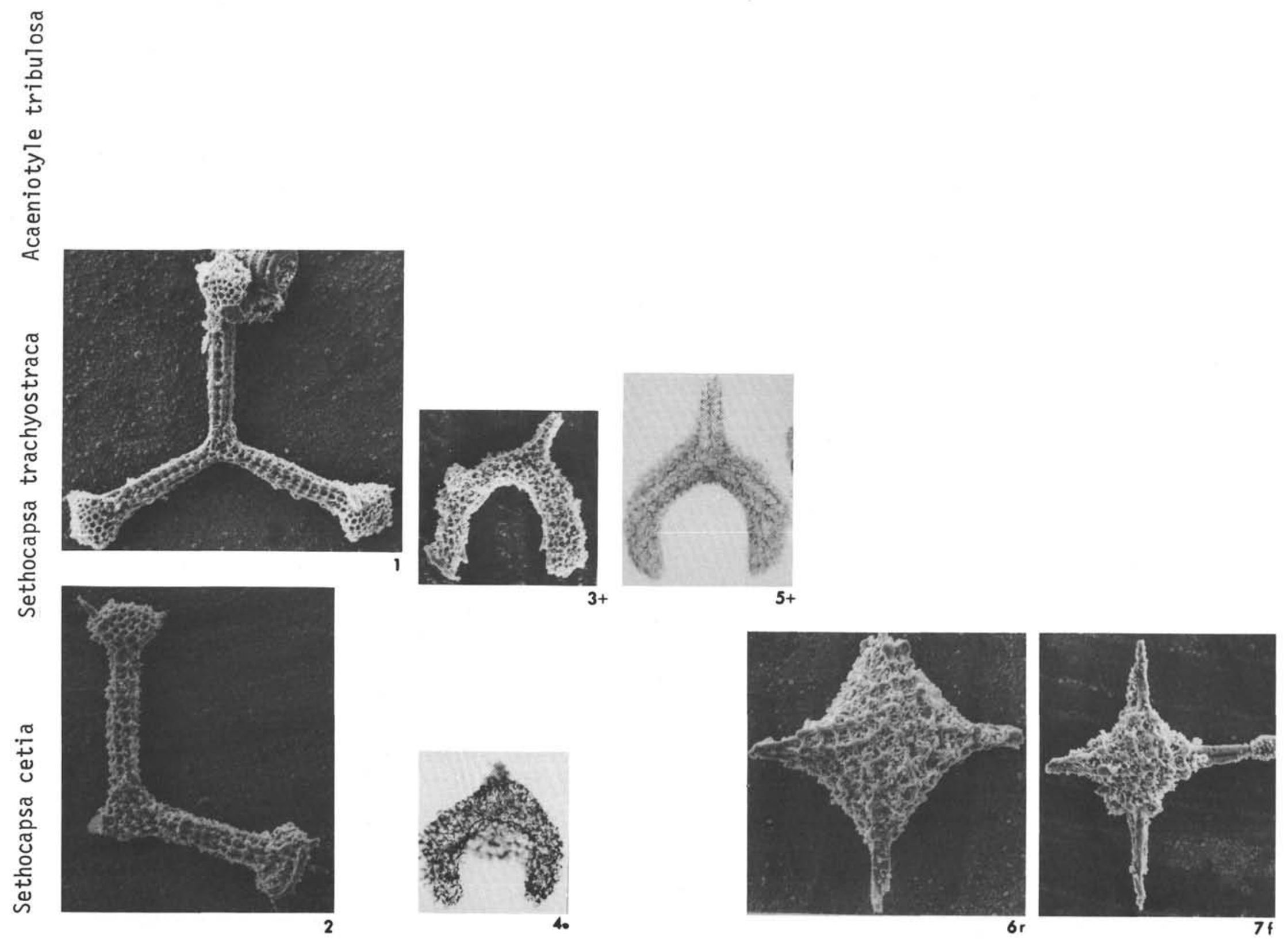


\section{PLATE 9}

Magnification: $\times 112$ for Figures 1, 2, 6-11; $X 116$ for Figures 3, 5; X 105 for Figure 4

Figures 1,2 Alievium sp.

1. Illustrated specimen USNM 189044.

2. sl. 1592-2-3.

Figures 3,4 Amphipyndax (?) sp.

3. cs. S W31/1.

4. cs. T J56/1.

Figure $5 \quad$ Amphipyndax (?) sp. $\mathrm{Ph} . \mathrm{R}$ W46/0.

Figure $6 \quad$ Dictyomitra (?) sp. sl. 1626-2-3.

Figure 7 Dictyomitra sp.

sl. 1592-4-7.

Figures 8,9 Dictyomitra sp. cf. D. spicularia Aliev.

8. sl. 1621-2-2.

9. s1. 1673-4-9.

Figure 10 Dictyomitra alievi Foreman n.sp. Holotype USNM 189047.

Figure 11 Dictyomitra cosmoconica Foreman n.sp. Holotype USNM 189049. 


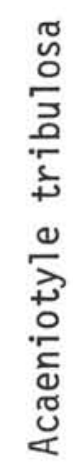
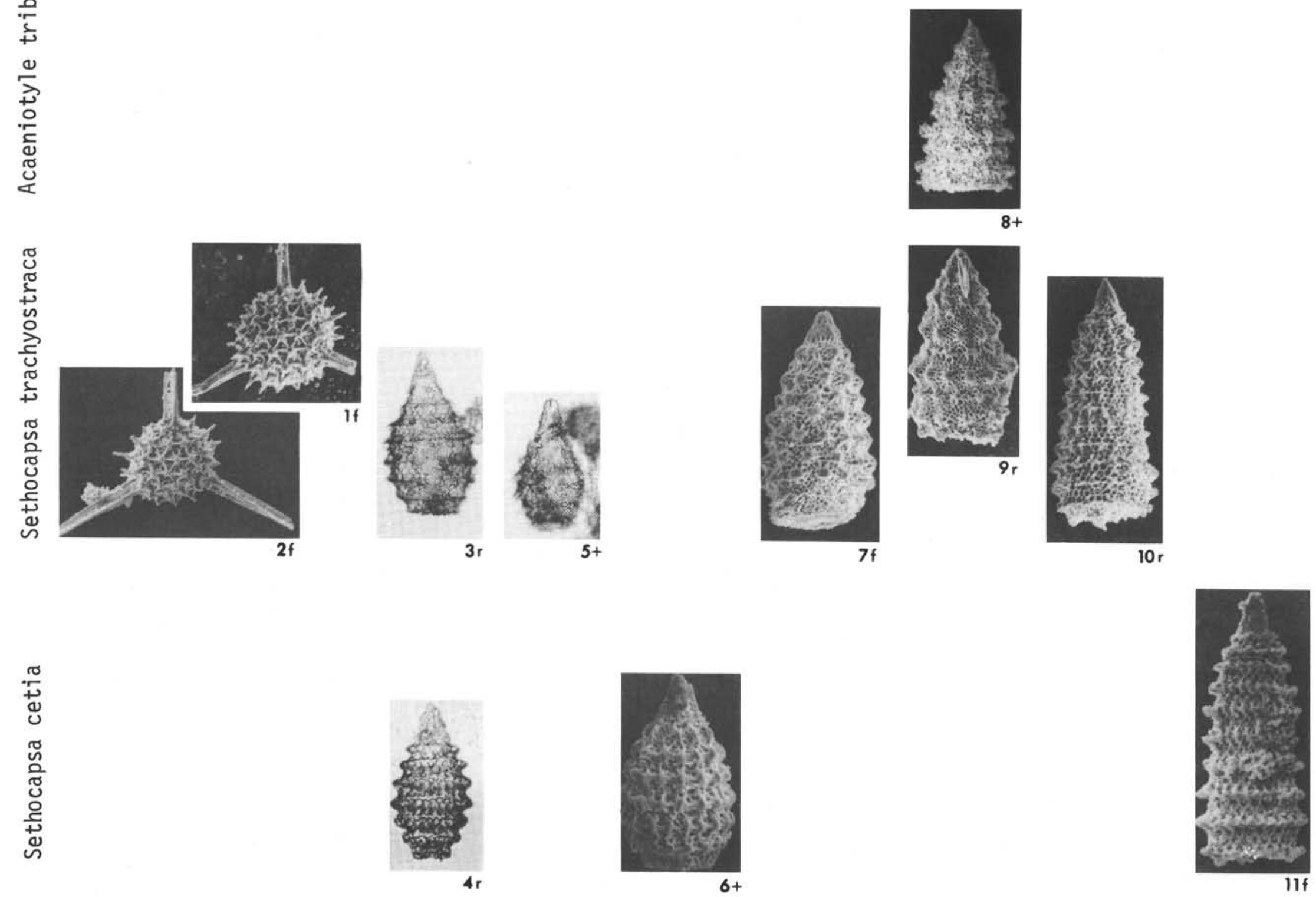


\section{PLATE 10}

Magnification: $X 112$ for Figures 4-6, 8-11, 13-19;

$$
\times 116 \text { for Figures 1-3, 7, } 12
$$

Figures 1-3 Dictyomitra carpatica (?) Lozyniak.

1. cg. sl $5038 / 2$.

2. Holotype USNM 289048 , F $30 / 3$.

3. cs. S L18/4.

Figure 4 Dictyomitra leptoconica Foreman n.sp. Holotype USNM 189051.

Figure 5 Dictyomitra sp.

sl. 1621-2-1.

Figure 6 Dictyomitra sp.

sl. $1592-4-5$.

\section{Figure 7 Dictyomitra sp.}

brch. fn. $1 \mathrm{M} 45 / 3$.

Figure 8

Dictyomitra sp.

sl. 1592-4-3.
Figures 9,10

Eucyrtis (?) zhamoidai Foreman n.sp.

9. sl. 1621-1-1.

10. Holotype USNM 189053.

Figure $11 \quad$ Dictyomitra (?) lacrimula Foreman n.sp. Holotype USNM 189050.

Figure 12 Dictyomitra (?) sp.cf.D. (?) lacrimula Foreman. sl. R W10/3.

Figures 13-15 Tripilidium (?) sp. A

13. sl. $1661-4-4$

14. sl. $1651-4-1$

15. sl. $1638-3-3$

Figures 16-18 Tripilidium (?) sp. B.

16. sl. $1462-3-2$.

17. sl. 1638-3-2.

18. Specimen lost.

Figure 19

Tripilidium (?) sp. C. sl. 1462-3-1. 

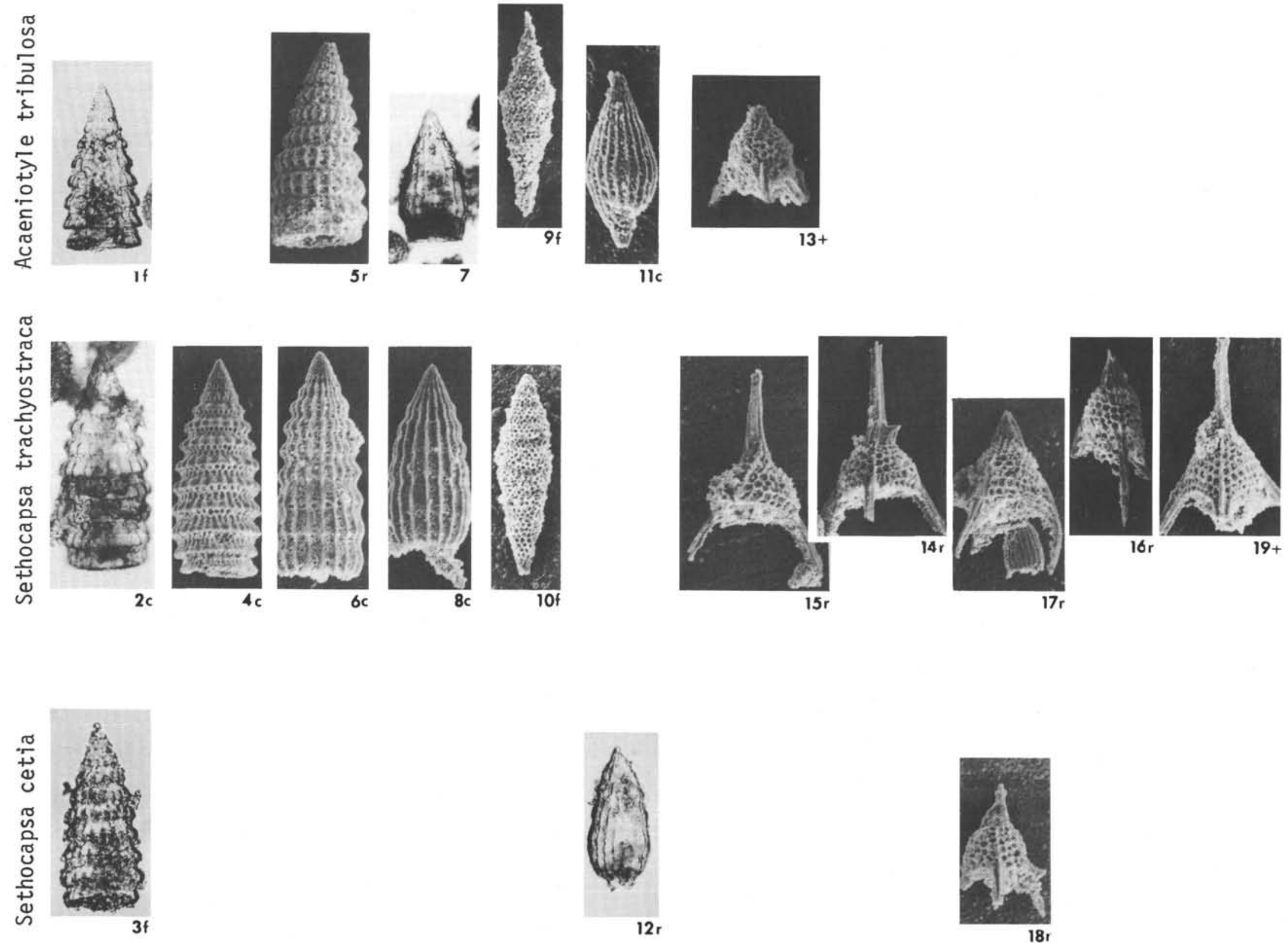


\section{PLATE 1}

Magnification: $X 117$ for Figure 1;

$\times 112$ for Figures $2-9$

Figures 1,2 Stichocapsa (?) rotunda Hinde.

1. cs. B $030 / 0$.

2. Illustrated specimen USNM 189052.

Figure 3 Dibolachras apletopora Foreman n.sp.

sl. 1626-4-4.

Figure 4 Dibolachras tytthopora Foreman n.sp. Holotype USNM 189055.

Figure $5 \quad$ Syringocapsa agolarium Holotype USNM 189064.

Figures 6,7 Syringocapsa limatum Foreman n.sp.

6. Lost.

7. sl. 1668-3-1.

Figures 8,9 Podobursa (?) polylophia Foreman n.sp.

8. Holotype USNM 189056.

9. Lost. 
\begin{tabular}{l}
0 \\
0 \\
0 \\
$\vdots$ \\
0 \\
$\vdots$ \\
+ \\
0 \\
$\frac{1}{7}$ \\
.0 \\
\hdashline \\
0 \\
0 \\
0 \\
0
\end{tabular}
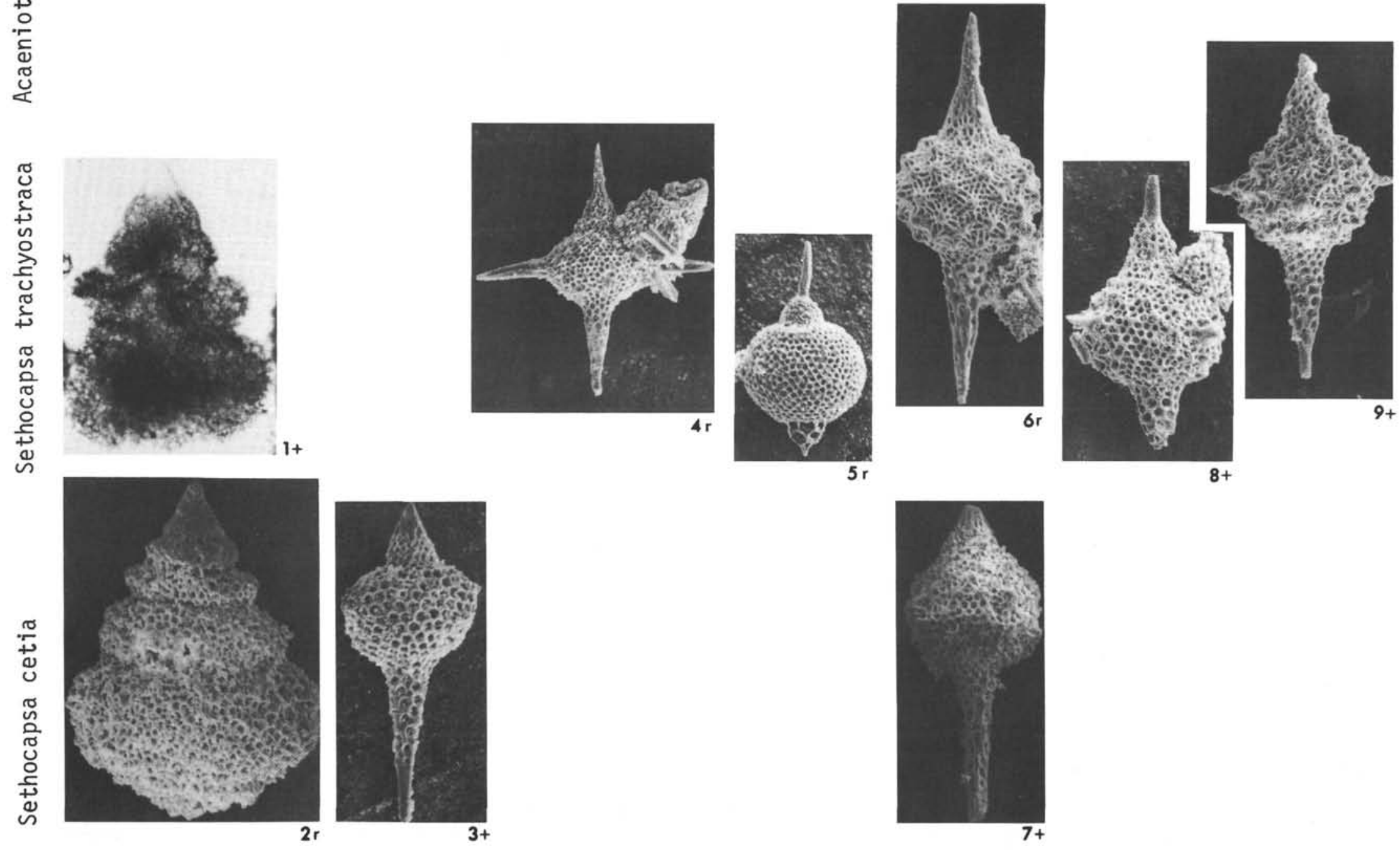
PLATE 12

Magnification: $\times 112$ for Figures 1-5;

$\times 117$ for Figure 6

Figure 1 Sethocapsa cetia Foreman n.sp.

Holotype USNM 189061.

Figure 2 Theoperid, Gen. and sp. indet.

sl. 1626-5-2.

This form is also present in the Sethocapsa

trachyostraca assemblage.

Figure 3 Theoperid, Gen. and sp. indet.

sl. 1569-5-2.

Figure 4 Sethocapsa trachyostraca Foreman n.sp. Holotype USNM 189063.

Figures 5,6 Sethocapsa leiostraca Foreman n.sp.

5. Holotype USNM 189062.

6. cs W $021 / 3$. 
0
0
0
5
0
$\vdots$
5
0
0
$\frac{1}{7}$
.0
.0
0
0
0
0
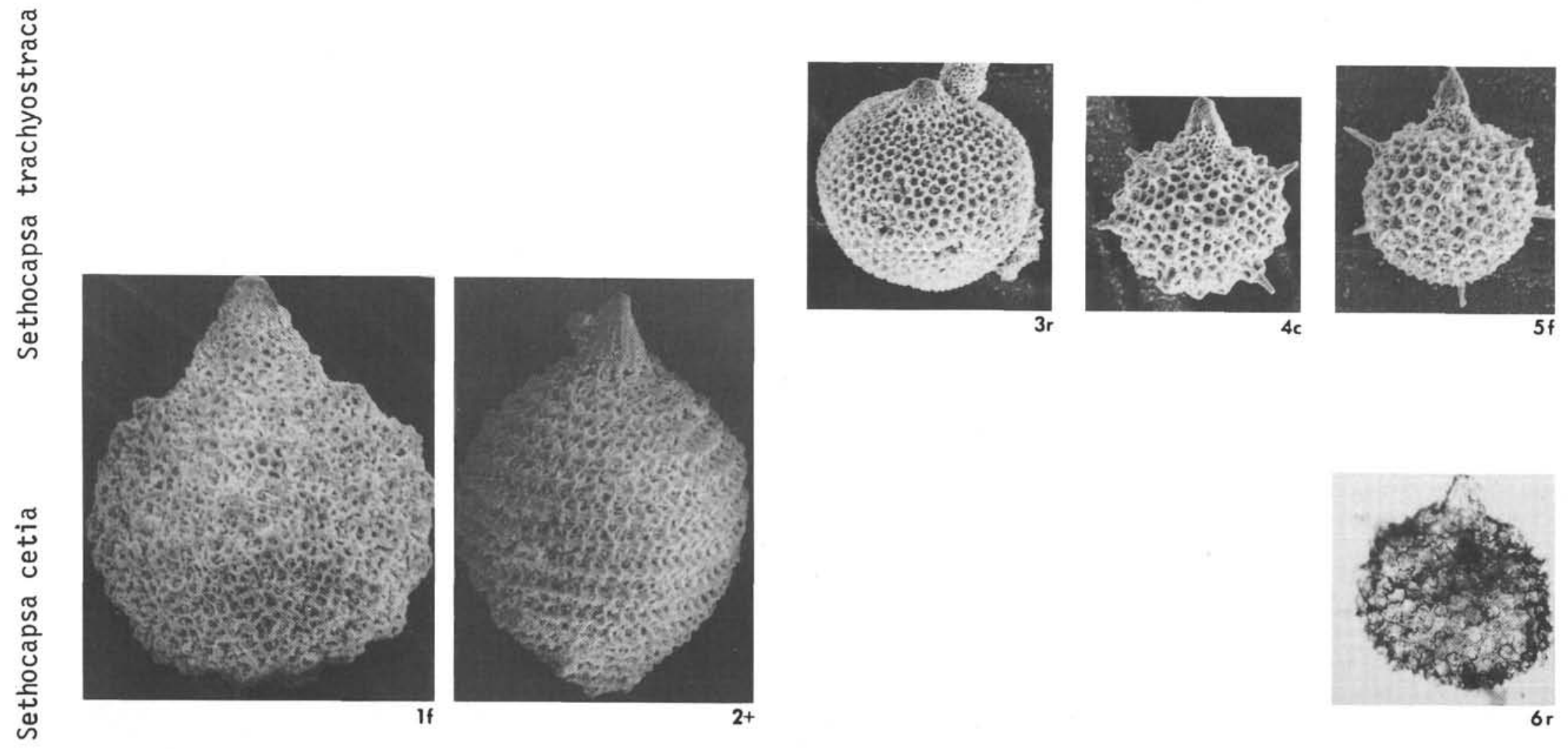
PLATE 13

Magnification: $\times 112$ for Figures 1-7, 10, 11;

$$
\times 116 \text { for Figures 8, } 9
$$

Figures 1-7 Podobursa triacantha (Fischli).
1. sl. 1638-2-4.
2. sl. 1626-4-3.
3. Illustrated specimen USNM 189058.
4. sl. 1626-4-2.
5. sl. 1638-2-5.
6. sl. 1668-3-4
7. sl. $1614-4-4$

Figure $8 \quad$ Podobursa tricola Foreman (?) brch. cs. $1 \mathrm{~T} 13 / 0$.

Figure 9 Podobursa tricola Foreman n.sp. USNM 189059, H29/4.

Figure $10 \quad$ Podobursa tetracola Foreman n.sp. sl. 1668-3-3.

Figure $11 \quad$ Podocapsa amphitreptera Foreman n.sp. Holotype USNM 189060. 


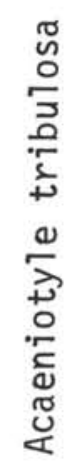
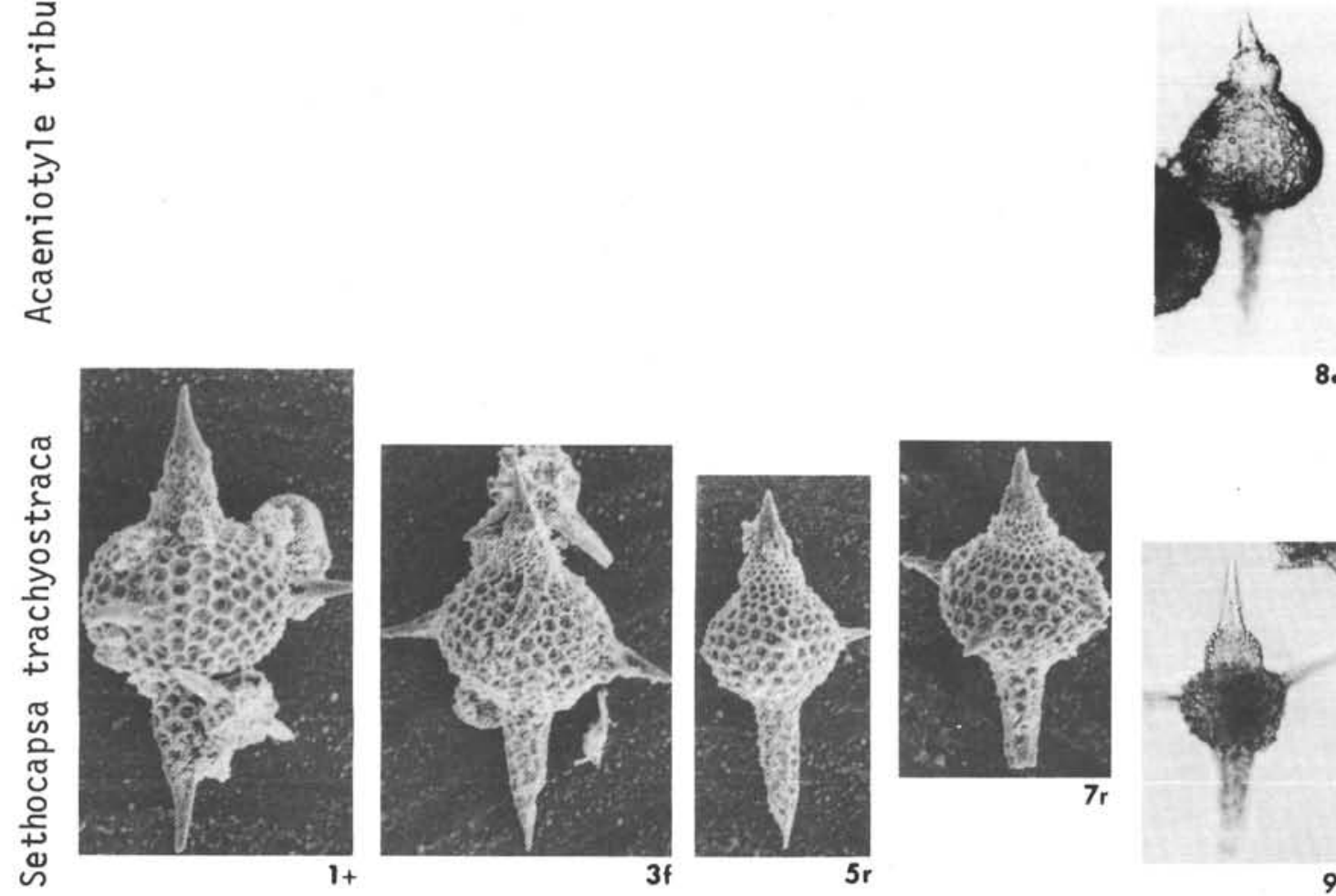

8.
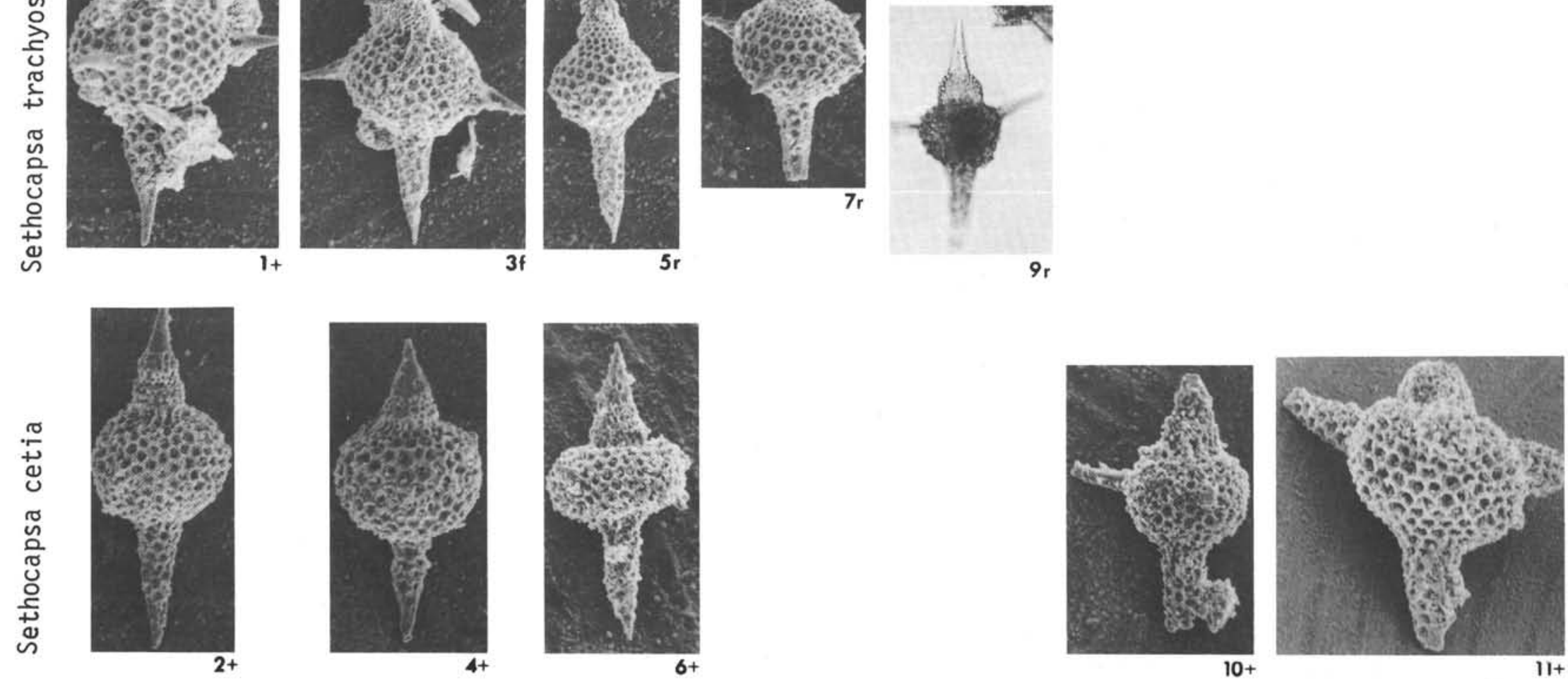
PLATE 14

Late Cretaceous, possibly Cenomanian Radiolaria (Magnification: $\times 112$ for Figures 1-8, 10, 12, 15, 18-20;

$\times 100$ for Figure $9 ; \times 116$ for Figures $11,13,14,16,17)$

Figure $1 \quad$ Spongosaturnalis (?) sp. cf. S. (?) aculeatus (?) (Rüst). sl 1687-1-4.

Figure 2 Spongosatumalis (?) sp. cf. S. (?) aculeatus (?) (Rüst). sl 1687-1-2.

Figure $3 \quad$ Spongosaturnalis (?) sp. cf. S. (?) aculeatus (?) (Rüst). si. 1687-1-3.

Figures 4, $5 \quad$ Spongosaturnalis (?) sp.

4. sl. 1687-2-4.

5. sl. 1687-2-1.

Figures 6,7 Spongosaturnalis (?) sp.

6. sl. 1362-2-1.

7. sl. $1687-2-2$.

Figure $8 \quad$ Spongosaturnalis (?) sp. sl. 1687-2-1.

Figure $9 \quad$ Spongosaturnalis (?) sp. whor. sl. 3 E30/2.

Figure $10 \quad$ Spongosaturnalis (?) sp. cf. Zygostephanus aculeatus Rüst (?) In Holmes, 1900.

sl 1687-1-1.

Figure $11 \quad$ Dictyomitra veneta (Squinabol). gch. sl. 2 U31/1.

Figures 12,15 Alievium sp. cf. A. praegallowayi Pessagno.

12. sl. 1687-3-1.

15. sl. $1687-3-4$.

Figure 13 Theoperid, Gen. and sp. indet. cf. Theoperid, Gen. and sp. indet. Foreman, 1971, pl. 3, fig. 1.

Br. 6 sl. 1 P32/0.

Figure 14 Theoperid, Gen. and sp. indet. gch. sl. 1 N29/2.

Figure 16 Dictyomitra sp. gch. cs. $1 \mathrm{M} 41 / 1$.

Figure $17 \quad$ Lithomelissa (?) sp. sl. $2 \mathrm{M} 46 / 0$.

Figure 18 Dictyomitra somphedia Foreman n. sp. Holotype USNM 189066.

Figure 19

Dictyomitra (?) sp. aff. Lithostrobus rostovzevi Lipman.

sl. $1687-4-4$.

Figure 20 Theoperid, Gen. and sp. indet.

sl. 1687-5-3.

The depressed area at the top of the shell may indicate a hidden cephalis. 

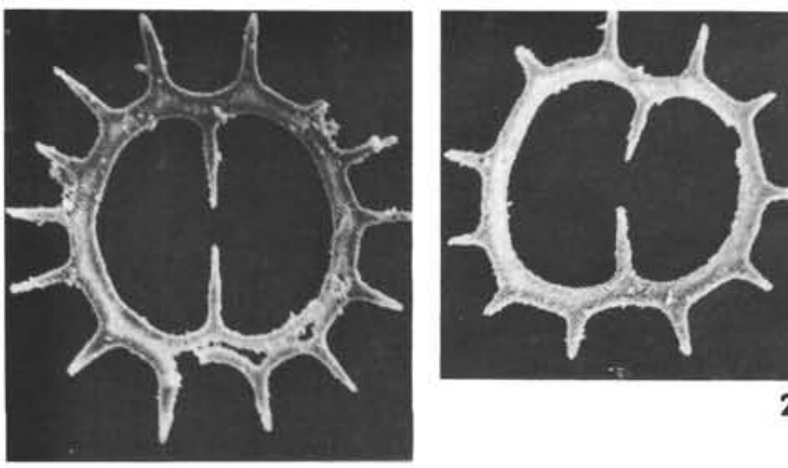

2
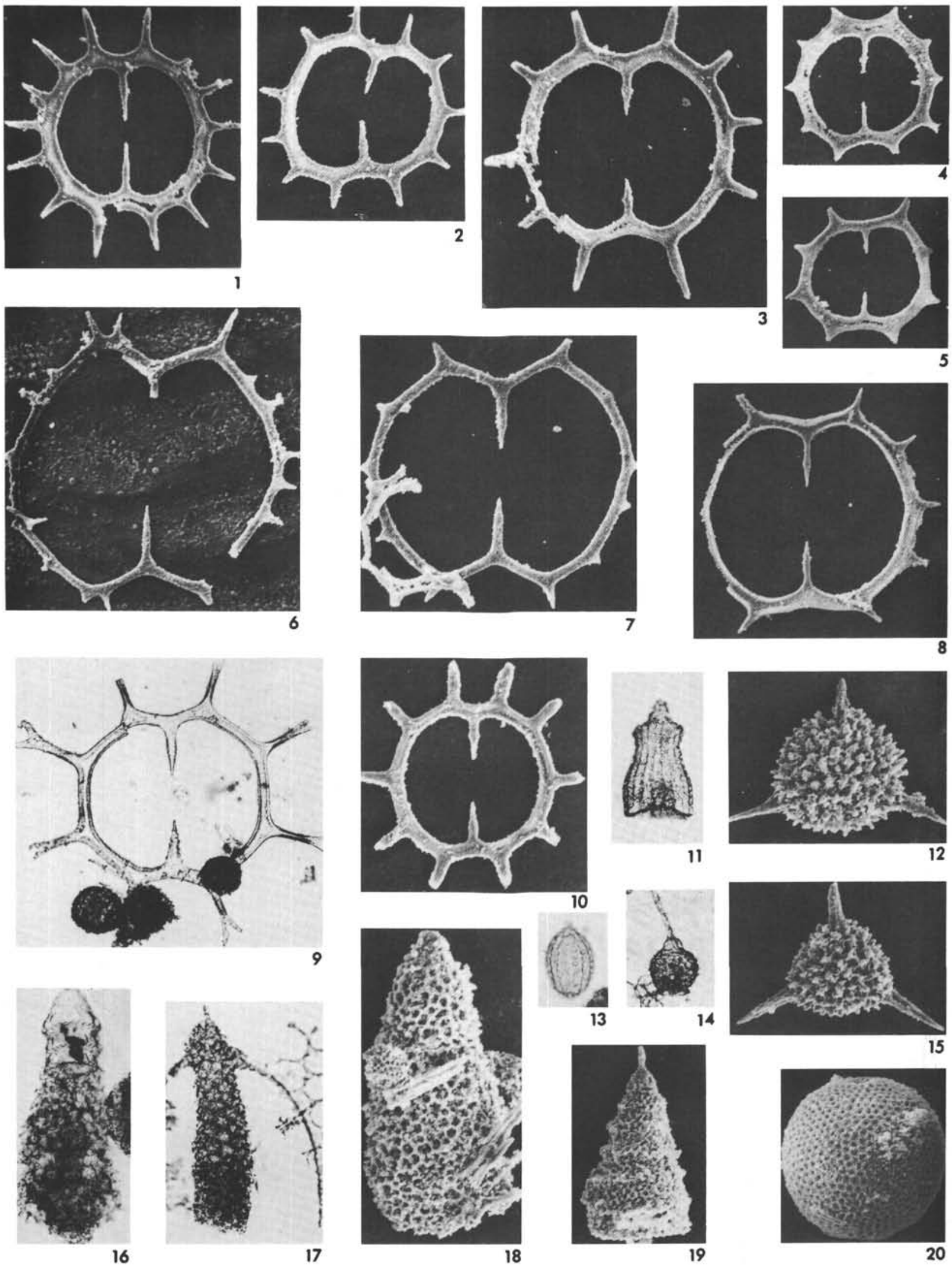
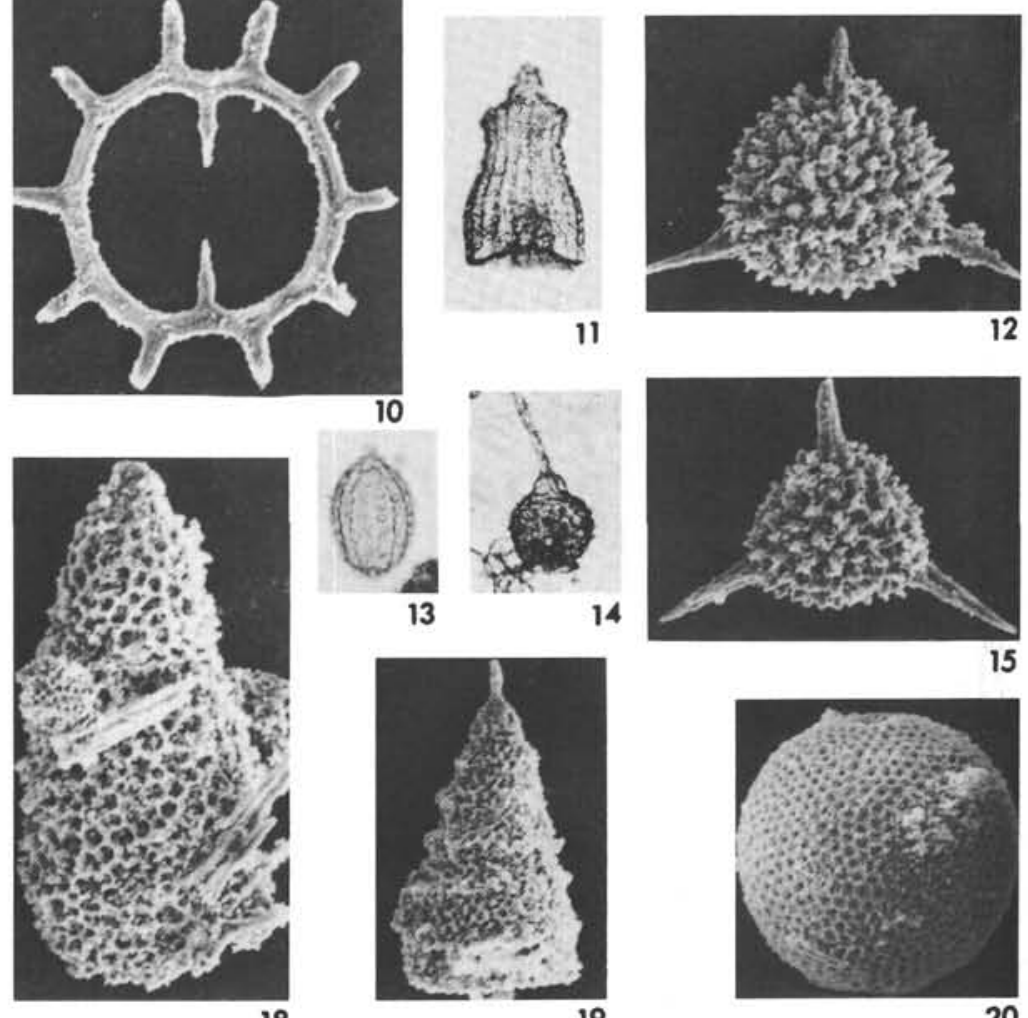

15

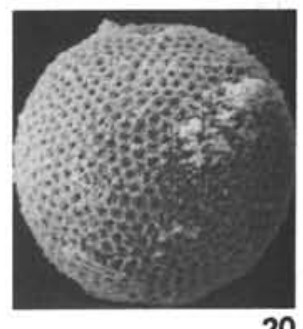

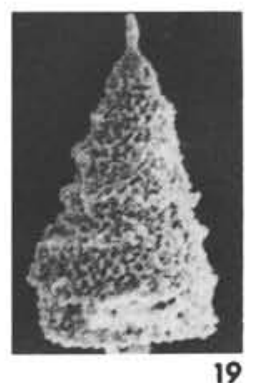

20 


\section{PLATE 15}

Campanian Radiolaria

Figure 1 Actinommid, Gen. and sp. indet. sl. 3 A34/3; 196-2-4, 26-28; X 117.

Figures 2, $3 \quad$ Spongosaturnalis (?) sp.

2. cs. $4 \mathrm{Q} 18 / 0 ; 198 \mathrm{~A}-4, \mathrm{CC} ; \times 117$.

3. cs. 4 M16/0;198A-4, CC; $\times 117$.

Figure $4 \quad$ Spongosaturnalis (?) multidentatus (Squinabol). sl. 1 R20/3; 198A-4, CC; X 117.

Figure 5 Spongosaturnalis (?) sp. cf. Saturnalis euganeus Squinabol in Foreman, 1971, p. 1674, pl. 1, fig. 5. cs. 5 R47/3; 198A-4, CC, X 117.

Figures 6,7 Spongosaturnalis (?) sp. in Foreman, 1971, p. 1674, pl. 1, fig. 4.

6. sl. 1 Q14/0;198A-4, CC; $\times 117$.

7. cs. $8 \mathrm{M} 41 / 1 ; 198 \mathrm{~A}-4, \mathrm{CC} ; \times 117$.

Figure 8 Acanthocircus sp. cs. 8 L23/2; 198A-4, CC; X 117.

Figures 9-11 Dictyomitra torquata Foreman.

9. sl. $1629-2-1 ; 196-2-4 ; \times 112$.

10. ph. 2 D40/2; 196-2-4; 26-28, X 116 .

11. ph. 1 Y $25 / 0 ; 198 \mathrm{~A}-4, \mathrm{CC} ; \times 116$.

Figure 12 Theocampe salillum Foreman. ph. 1, K24/1;198A-4, CC; × 116.

Figures 13-15 Dictyomitra sp. in Foreman, 1971, p. 1677, pl. 3, fig. 5 .

13. sl. $1629-2-2 ; 196-2-4,26-28 ; \times 112$.

14. ph. $2033 / 2 ; 196-2-4,26-28 ; \times 116$.

15. ph. $1 \mathrm{~S} 31 / 1 ; 198 \mathrm{~A}-4, \mathrm{CC} ; \times 116$.

Figure 16 Cryptamphorella sphaerica (White) in Dumitrica, 1970 , p. 82 , pl. 12 , figs. 73a, b, 74a, b. ph. $1 \mathrm{~K} 24 / 1 ; 198 \mathrm{~A}-4, \mathrm{CC}$; $\times 116$.

Figure 17 Theoperid, Gen. and sp. indet. in Foreman, 1971, p. 1676, pl. 3, fig. 1. ph. 1 G36/0; 198A-4, CC; X 116.

Figure 18 Pseudoaulophacus pargueraensis Pessagno. cs. 8 L23/0; 198A-4, CC; $\times 116$.

Figure 19 Amphipyndax enesseffi Foreman. sl. B D21/1; 198A-4-5; X 116.

Figure 20 Theocampe apicata Foreman. ph. $1 \mathrm{~L} 30 / 4 ; 198 \mathrm{~A}-4, \mathrm{CC} ; \times 116$.

Figure 21 Theocampe urna Foreman. st. B J23/4; 198A-4-5, 27-29; X 116.

Figures 22,23 Theoperid, Gen. and sp. indet. in Foreman, 1971, p. 1676, pl. 3 , fig. 3 .

22. sl. B C13/0; 198-4-5, 27-29; X 117; Apical view. 23. sl. B R13/4; 198-4-5, 27-29; X 116; Side view. 

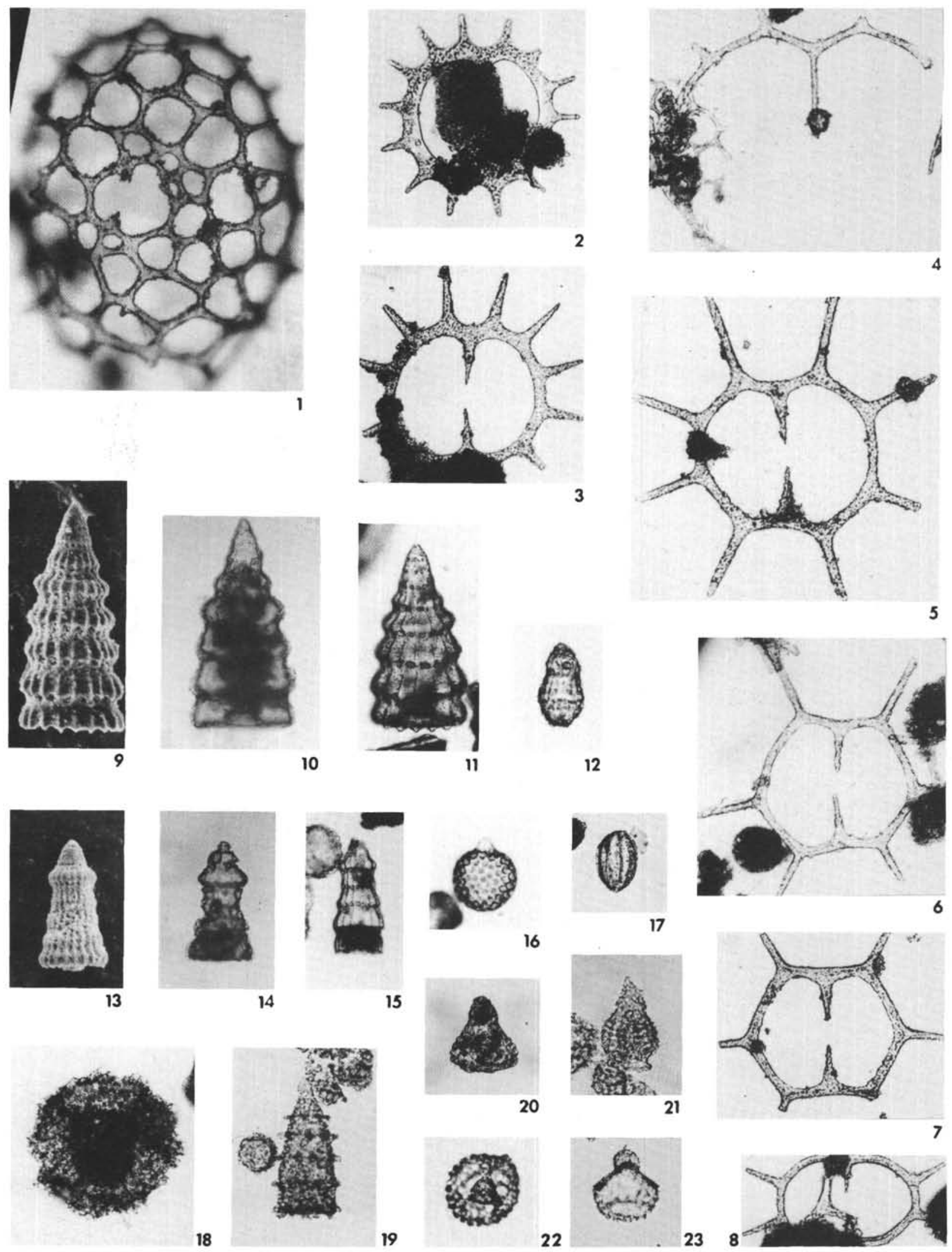

22
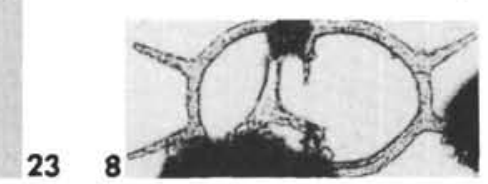
PLATE 16

Neocomian Radiolaria

Figures 1,2 Eucyrtis (?) zhamoidai Foreman n. sp.

1. ph. R C47/0; 196-4-1, piece $3 ; \times 116$.

2. sl. R X29/3;196-3-1, piece $3 ; \times 116$; Internal cast.

Figure 3 Dictyomitra cosmoconica Foreman n. sp. cs. T E34/0; 196-5, CC; X 116.

Figure 4 Dictyomitra alievi Foreman n. sp. cs. 4 K28/2; 196-4-1, piece 3 ; X 116.

Figure $5 \quad$ Dictyomitra carpatica Lozyniak (?). ph. R D13/1;196-4-1, piece 3 ; X 116.

Figure 6 Dictyomitra leptoconica Foreman n. sp. cs. R V26/3; 196-4-1, piece 3 ; X 116.

Figure 7 Dictyomitra sp. sl. 5a M44/0; 195-5, CB; X 116.

Figure 8 Syringocapsa limatum Foreman n. sp. Holotype USNM 189065, M16/0; 196-3-1, piece 3; X 110.

Figure 9 Triactoma cellulosa Foreman n.sp. cs. R D33/4; 196-4-1, piece 3 ; X 116.

Figures 10,11 Dibolachras apletopora Foreman n. sp.

10. Holotype USNM 189054, C15/4; 196-5, CC; X 117.

11. P1824 P38/0; 196-5, CC; X 117.

Figure 12 Podobursa tricola Foreman n. sp. cs. S Q24/0; 194-4-1, piece 3; X 110.

Figure $13 \quad$ Podobursa sp. aff. $P$. triacantha (Fischli). sl. $1638-2-1 ; 196-4-1$, piece $3 ; \times 112$.

Figure 14 Podobursa tetracola Foreman n.sp. Holotype USNM 189057, H23/3; X 117.

Figure 15 Dibolachras tytthopora Foreman n. sp. cs. S F33/2;196-4-1, piece $3 ; \times 116$.

Figure 16 Acaeniotyle sp. aff. A. diaphorogona Foreman. sl. 3 F18/0; 195B-2, CC; X 117.

Figure 17 Syringocapsa agolarium Foreman n. sp. cg. cs. T B14/4; 196-3-1, piece $3 ; \times 116$.

Figure $18 \quad$ Acanthocircus sp. aff. Saturnalis variabilis Squinabol. sl. S D17/3; 196-3-1, piece $2 ; \times 117$.

Figure 19 Sethocapsa cetia Foreman n. sp. cs. T D43/0; 196-5, CC; X 117.

Figure $20 \quad$ Stichocapsa (?) rotunda $\mathrm{H}$ inde. cs. T E53/0; 196-5, CC; X 117.

Figure 21 Triactoma echiodes Foreman n. sp. cg. cs. T J47/3; 196-3-1, piece $3 ; \times 116$.

Figure 22 Acanthocircus trizonalis (Rüst) (?). cs. 5 K $35 / 2 ; 1964-1$, piece $3, \times 116$. Side view showing width and shape of saddles at ends of elliptical ring.

Figure 23 Acanthocircus sp.

cg. cs. T L19/1; 196-3-1, piece 3 ; X 117. Transitional form between $A$. dizonius (?) and $A$. trizonalis (?).

Figure 24 Staurosphaera glebulosa Foreman n. sp. cs. S B35/0; 196-4-1, piece 3 ; X 117. 

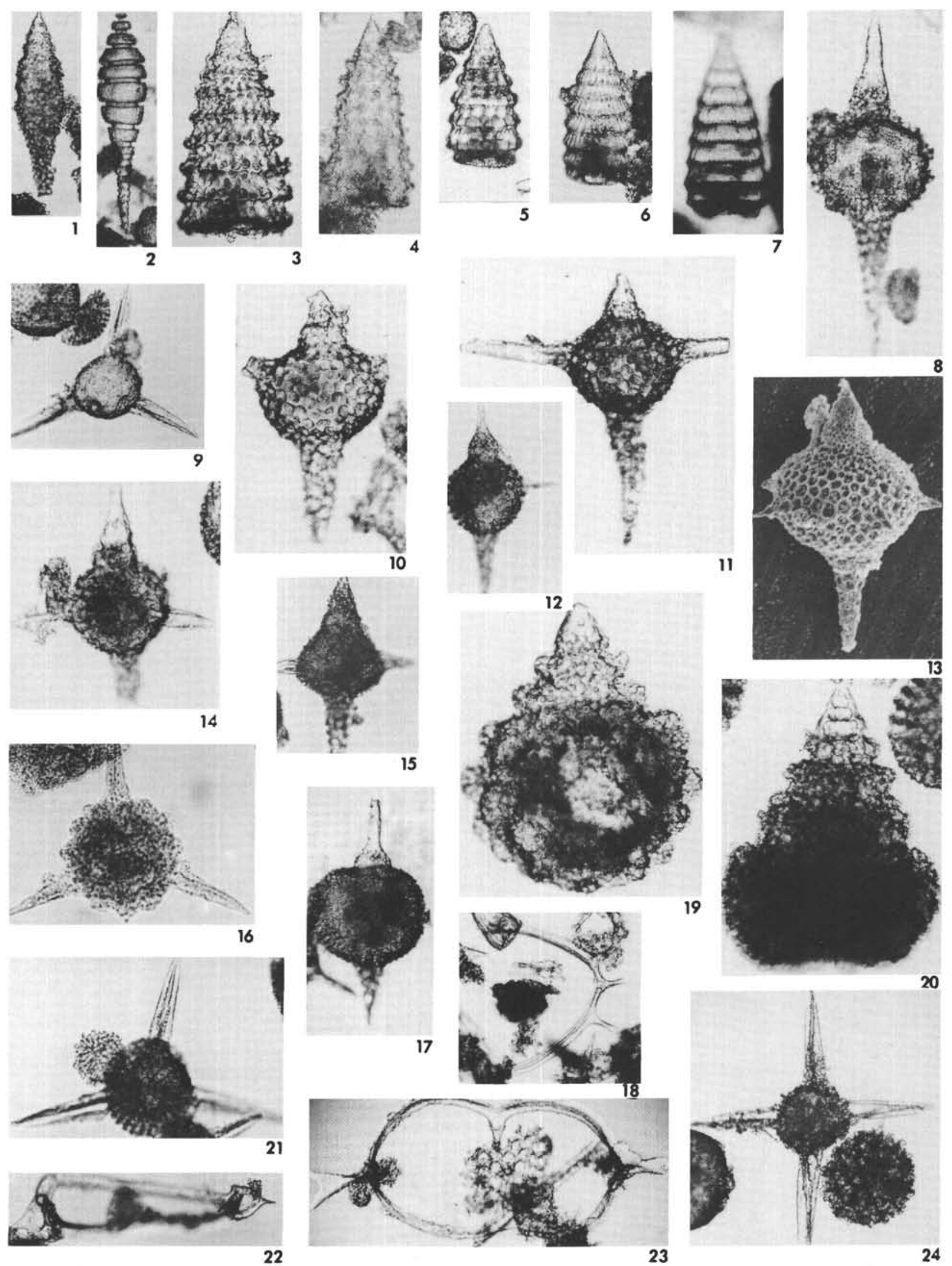


\section{INDEX OF RADIOLARIAN NAMES}

Only radiolarian genera and species group taxa are indexed. The main entry and illustration are given in bold-face type. These are preceded by entries concerning occurrence and stratigraphic range and followed by entries in which the name occurs in a general discussion. Taxa listed on tables and figures are not indexed.

Acaeniotyle, 258, 259

diaphorogona, 258 ; pl. 2, fig. 2-5

tribulosa, 257, 258; pl. 2, fig. 8

umbilicata, 256, 258; pl. 1, fig. 12-14, 16

sp. aff. A. diaphorogona, pl. 2, fig. 6, 7; pl. 16, fig. 16

sp. aff. A. umbilicata, pl. 1, fig. 15

Acanthocircus, 260

carinatus, $257 ; 260 ;$ pl. 5 , fig. 1,2

transitional form? A. carinatus - A. sp. aff. S. variabilis, pl. 5, fig. 3

dizonius (?), 256, 257, 260, 261; pl. 4, fig. 4, 5

irregularis, 260

trizonalis (?), 260, 261; pl. 4, fig. 6-8; pl. 16, fig. 22

sp. 'aff. Saturnalis variabilis, 260 , 261; pl. 5, fig. 4, 5; pl. 16, fig. 18

sp., pl. 15, fig. 8; pl. 16, fig. 23

Actinommid

Gen. and sp. indet., pl. 1, fig. 1-6; pl. 15, fig. 1

Adelocyrtis, 267

pala, 267

Alievium, 262

praegallowayi, 262

sp. cf. A. praegallowayi $262 ;$ pl. 14 , fig. 12,15 sp., $262 ;$ pl. 9, fig. 1

Amphipyndax, 263

enesseffi, 256, 263; pl. 15, fig. 19

(?) spp., 263; pl. 9, fig. 3-5

Artostrobium miralestense, 255

urna, 256

Axoprunum angelinum, 249

Cryptamphorella sphaerica, pl. 15, fig. 16

Cyrtocalpis duodecimradiata, 264

Cyrtocapsella cornuta, 256

Dibolachras, 265

apletopora, 265, 266; pl. 11, fig. 3; pl. 16, fig. 10, 11 tytthopora, 257,265 ; pl. 11, fig. 4 ; pl. 16, fig. 15

Dictyomitra, 263

alievi, 257,263 ; pl. 9, fig. 10; pl. 16, fig. 4

carpatica (?), 263, 264; pl. 10, fig. 1-3; pl. 16, fig. 5

cosmoconica, 255, 263; pl. 9, fig. 11; pl. 16, fig. 3

(?) lacrimula, 257, 263; pl. 10, fig. 11

leptoconica, 256,264 ; pl. 10 , fig. 4 ; pl. 16, fig. 6

multicostata, 263

nassa, 263

somphedia, 251 , 264 ; pl. 14, fig. 18

spicularia, 264

torquata, $256 ;$ pl. 15, fig. 9-11

turritella, 264

veneta, 264; pl. 14, fig. 11

(?) sp. cf. D. (?) lacrimula, pl. 10, fig. 12

sp. cf. D. spicularia, $264 ;$ pl. 9, fig. 8,9

(?) sp. aff. Lithostrobus rostovzevi, 264; pl. 14, fig. 19

sp. in Foreman, 1971, 256; pl. 15, fig. 13-15

sp., 264 ; pl. 14, fig. 16

sp., pl. 9, fig. 7; pl. 10, fig. 5-8; pl. 16, fig. 7

(?) sp., pl. 9, fig. 6

Emiluvia, 262

chica, 257, 262, 263; pl. 8, fig. 7

pessagnoi, $256 ; 257,262 ;$ pl. 8 , fig. 6

Eucyrtidium matuyami, 249, 251

tumidulum, 249; 255

Eucyrtis, 264

conoidea, 264

(?) zhamoidai, 264; pl. 10, fig. 9, 10; pl. 16, fig. 1, 2
Eusyringium affine, 267

typicum, 267

sp. A, 264

Hagiastrid

Gen. and sp. indet., pl. 5, fig. 6-8; pl. 6, fig. 3, 5, 6; pl. 7, fig. 1-7

Hagiastrid (?)

Gen. and sp. indet., pl. 6, fig. 1, 2, 4

Lamprocyrtis haysi, 249

heteroporos, 249,251

Lithatractus sp., 258; 259

Lithobotrys uva, 267

Lithocampe fasciata, 263

Lithomelissa (?) sp., pl. 14, fig. 17

Lithopera bacca, 256

Lithostrobus rostovzevi, 264

? Mayenella hensoni, $258 ; 259$

Ommatartus avitus, 250;251

penultimus, 250

Paronaella, 262

(?) diamphidia, $261 ; 262$; pl. 8, fig. 3, 4

? ewingi, 262

(?) ewingi (?) 262 ; pl. 8, fig. 1

solanoensis, 262

sp. aff. $P$. (?) diamphidia, pl. 8 , fig. 5

(?) sp., 262; pl. 8, fig. 2

Phormocyrtis veneta, 264

Podobursa, 256;257;265;266

dunikowskii, 266

(?) polylophia, 266; pl. 11, fig. 8, 9 tetracola, 266; 267; pl. 13, fig. 10; pl. 16, fig. 14

triacantha, $266 ; 267 ;$ pl. 13 , fig. 1-7

tricola, 267; pl. 13, fig. 9; pl. 16, fig. 12

tricola (?), pl. 13, fig. 8

sp. aff. $P$. triacantha, pl. 16, fig. 13

Podocapsa, 265;266;267 amphitreptera, $257 ; 267 ;$ pl. 13, fig. 11 guembelii, 267

Protoxiphotractus (?) fischeri, 258; 259

Pseudoaulophacus pargueraensis, pl. 15, fig. 18

Pterocanium prismatium, 251

Rhopalosyringium sp., 256

Saturnalis discranacanthos, 260

multidentatus, 261

variabilis, 261

(?) aff. amissus, 261

Saturnulus dizonius, 260

trizonalis, 261

sp., 260, 261

Sethocapsa, $265 ; 267$

cetia, 256, 257, 267; pl. 12, fig. 1; pl. 16, fig. 19

cometa, 267

leiostraca, $255 ; 268 ;$ pl. 12 , fig. 5,6

polymasta, 268

spinosa, 268

trachyostraca, $254 ; 255 ; 268 ;$ pl. 12 , fig. 4

Sphaerostylus, 258

lanceola, 259

lanceola group, $255 ; 256 ; 258 ;$ pl. 1, fig. 7-11

zittelii, 258

Spongaster klingi ?, 250

tetras, 256

tetras tetras, $250 ; 251 ; 256$

Spongosaturnalis, 261

(?) aculeatus (?), 261; pl. 4, fig. 2

dicranacanthos, $256 ; 260$

(?) multidentatus, 261 ; pl. 15, fig. 4

spiniferus, 261

? suboblongus, 261 
(?) sp. aff. $S$. (?) aculeatus, 261 ; pl. 4, fig. 1, 3

(?) sp. cf. $S$. (?) aculeatus (?) 261; pl. 14, fig. 1-3

(?) sp. cf. Saturnalis euganeus, pl. 15, fig. 5

(?) sp cf. Zygostephanus aculeatus (?), 261; pl. 14, fig. 10

(?) sp. in Foreman, 1971, pl. 15, fig. 6, 7

(?) sp., 261; pl. 15, fig. 2,3

(?) sp., pl. 14, fig. 4-9

Staurolonche robusta, 259

sp., 259

Staurosphaera, 259

amplissima, 257; 259; pl. 3, fig. 6

crassa, 259

glebulosa, 259 ; pl. 3 , fig. 5 ; pl. 16, fig. 24

septemporata, $255 ; 256 ; 257 ; 259 ;$ pl. 3 , fig. 4

Staurostylus, $266 ; 267$

Stichocapsa, 265

conglobata, 265

conosphaeroides, 267

fasciata, 263

jaspidea, 265

(?) rotunda, 256 ; 265 ; pl. 11, fig. 1, 2; pl. 16, fig. 20

verbana, 265

Stichocorys delmontensis, $251 ; 256$

peregrina, $250 ; 251$

wolffii, 256

Stylacontarium acquilonium, 249

Stylatractus ovatus, $258 ; 259$

paronae, $258 ; 259$

tener, $258 ; 259$

universus, 256

Stylosphaera lanceola, $258 ; 259$

squinaboli, $258 ; 259$

sp., $258 ; 259$

Stylostaurus sp., $266 ; 267$

Syringocapsa, $265 ; 268$

agolarium, 256;257;268; pl. 11, fig. $5 ;$ pl. 16, fig. 17

limatum, $255 ; 266 ; 268 ;$ pl. 11, fig. 6,7 ; pl. 16, fig. 8

Theocampe apicata, pl. 15, fig. 20

salillum, 256; pl. 15, fig. 12

urna, pl. 15, fig. 21
Theodiscus cretaceus, 260

superbum, 262

Theoperid

Gen. and sp. indet., pl. 12, fig. 2, 3; pl. 14, fig. 14, 20

Gen. and sp. indet. cf. Theoperid, Gen. and sp. indet. Foreman, 1971 , pl. 14, fig. 13; pl. 15, fig. 17, 22, 23

Theosyringium acanthophorum, 266

acanthophorum hexacanthus, 266

acanthophorum var. polyacanthus, 266

acanthophorum var. tetracanthus, 266

acanthophorum var. triacanthus, 266;267

larva, 266

robustum, 268

triacanthus, 267

Triactis, 259

Triactoma, 259

cellulosa, 259; 260 ; pl. 2 , fig. 9 , 10 ; pl. 16, fig. 9

echiodes, $257 ; 260 ;$ pl. 3, fig. 1; pl. 16, fig. 21

tithonianum, $256 ; 257 ; 259 ; 260$, pl. 2, fig. 1

sp. cf. T. echiodes, pl. 3, fig. 2, 3

Tripilidium, 265

bononiense, 265

debile, 265

nanum, 265

obliquum, 265

(?) sp. A, 265; pl. 10, fig. 13-15

(?) sp. B, 265; pl. 10, fig. 16-18

(?) sp. C, 265 ; pl. 10, fig. 19

Trisyringium, $265 ; 268$

capellini, 268

Urocyrtis, 265

Xiphosphaera manzonii, 258;259

umbilicata, 258

Xiphostylus felsinae, $258 ; 259$

Zygostephanus aculeatus (?), 261 